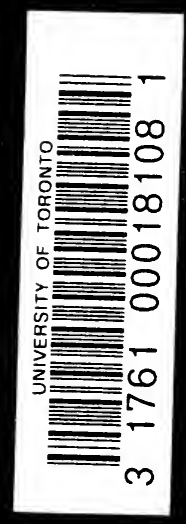







COLUMBIA UNIVERSITY STUDIES IN ENGLISH

\section{THE POLITICAL PROPHECY IN ENGLAND}




\author{
COLUMBIA \\ UNIVERSITY PRESS \\ SALES AGENTS \\ NEW YORK : \\ LEMCKE \& BUECHNER \\ 3c-32 West 27Th STREeT \\ LONDON : \\ HENRY FROWDE \\ AMEn Corner, E.C. \\ TORONTO : \\ HENRY FROWDE \\ 25 Richmond Street, W.
}




\title{
THE POLITICAL PROPHECY IN ENGLAND
}

\author{
BY \\ RUPERT TAYLOR, Ph.D.
}

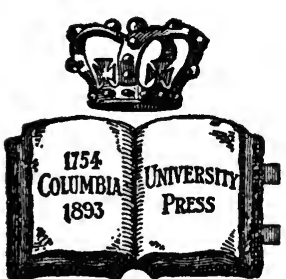

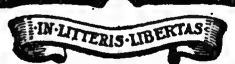

解战侽ork

THE COLUMBIA UNIVERSITY PRESS

I9 I I

All rights reserved 


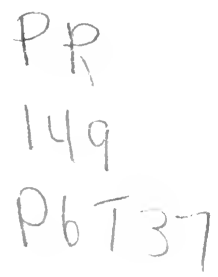

Copyright, I9I I

By The Columbia University Press

Printed from type July, xgr I

Press of

The NEW ERA PRINTING COMPAMY

LANCASTER, Pa. 
This Monograph has been approved by the Department of English in Columbia University as a contribution to knowledgc worthy of publication.

A. H. THORNDIKE,

Secretary. 

TO MY FRIEND,

MR. VICTOR FITCH BONSALL

OF NEW YORK CITY,

THIS BOOK IS RESPECTFULLY DEDICATED. 



\section{PREFACE}

No study of the political prophecy as a literary form has hitherto been published. The present work, therefore, opens a new field for investigation by students of literary history. In The Political Prophecy in England I have attempted only to show the general history of the type in England, with some reference to Continental activity in the same field, and make no pretense of detailed study. In fact, a thorough study of the subject is impossible at this time, for available material is too scanty and the whole field too large. I have, however, embodied in the book the results of my investigations in special subjects, such as the sources for Geoffrey of Monmouth's Book of Merlin, the date of Adam Davy's Dreams and the person of Adam Davy himself, and the interpretation of Thomas of Erceldoune. I do not pretend in any case to have written the final word.

I wish here to express my thanks to Mr. H. F. Schwarz, Dr. F. A. Patterson, Dr. F. H. Ristine of Columbia University, and Professor Mabel Buland of the University of Puget Sound for valuable references given me in the course of my investigations. I wish also to acknowledge my indebtedness to the librarians of Columbia, Harvard, Yale, Cornell and Johns Hopkins, to the Bodley Librarian, to the Comptroller of The Clarendon Press, and to the authorities of the British Museum and the Bibliothéque Nationale. I am also indebted to Professors J. L. Gerig and Raymond Weeks of Columbia University, to Mr. Mark Skidmore and to Miss L. Vimont for assistance in transcribing the old French printed in Appendix I. Special thanks are due Professor H. M. Ayres who has kindly advised me during the writing of the book, to Professor G. P. Krapp with whom I began this work in 1907 and to whom I owe many valuable suggestions, and to Professor W. W. Lawrence who has been in charge of the investigation since 1908. For assistance in reading the proof $\mathrm{I}$ am indebted to Professors Krapp and Lawrence, and to Mr. B. P. Adams of The Literary Digest.

RUPert TAYLOR.

New York City,

May 15, I9II. 



\section{SYNOPSIS OF THE DISSERTATION}

\section{CHAPTER I}

The Introduction of the Political Prophecy into England with Geoffrey of Monmouth's The Book of Merlin: Other Political Prophecies of the Twelfth Century in England.

I. Statement of the subject-scantiness of the material-difficulty of the subject-bibliography in a footnote.

II. General definition of the type.

I. It deals with political affairs.

2. It must have literary form-this necessity excludes the prophecy of the Witches in Macbeth and that of Peter of Pomfret.

3. The methods of delivering the prophecies.

a. Direct.

b. Symbolical.

I. The Sibyllic type-persons are referred to by the initial letters of their names.

2. The Galfridian.

III. Definition of the Galfridian type-date of introduction-c. II35.

r. The peculiar use of animal figures.

a. Explanation and quotation.

$b$. How the use here differs from the use of similar figures in the fable and in the allegory.

Here the animal names are mere cloaks or disguises for real individuals. In the fable the animals are chosen to typify traits of character common to many men, and the whole story is told to point a moral-In the allegory the animals are personifications of abstract ideas.

2. Other devices used to obtain obscurity.

Here the second essay of Bridlington, which treats the subject fully, is discussed.

3. Devices used to induce belief in the authenticity of the prophecies.

$a$. Actual history is retold as actual prophecy before the fictitious portion begins.

b. Prophecies were attributed to men of recognized authority as scholars, such as Bede, Gildas, etc., or to men reputed to be prophets, such as Merlin or Thomas of Erceldoune.

IV. The Book of Merlin.

I. The original version seems not to be extant-Geoffrey seems to have included much the same material in the Historia (Book 7). 


\section{xii}

What appears here and what is quoted by Ordericus Vitalis must serve for the reconstruction.

2. Description of the seventh book of the Historia.

a. The general introduction-Cap. I.

b. The dedicatory epistle-Cap. II.

c. The prophecies-Cap. III and IV.

3. These prophecies are really a collection.

$a$. Geoffrey always uses the plural noun.

b. Repeated motives.

r. The dragon motive-three quotations.

2. Mention of other repetitions.

4. The date of The Book of Merlin.

a. Before December II35-a passage quoted by Ordericus Vitalis in a chapter of Historia Ecclesiastica written before that date.

$b$. Internal evidence.

The last historical event that can be identified is the sinking of the White Ship-danger of interpreting episodes-Eagle-of-the-Broken-Covenant passage cannot refer to the war between Stephen and Matilda because it was written before the war arose. Caution necessary in the use of internal evidence thus gained.

5. The Libellus Merlini used by Ordericus was perhaps the original Book of Merlin-how the Libellus differed from the Historia.

a. Colors of the dragons interchanged.

b. Minor textual variances.

c. Perhaps furnished with notes or a commentary.

V. Consideration of Geoffrey's sources for The Book of Merlin postponed to the following chapter in order to discuss the other prophecies of the same century.

VI. The Vita Merlini.

I. The prophecy of Merlin here is a re-working of material in The Book of Merlin.

2. The Prophecy of Ganieda. Pure forgery, but written in accordance with the conventions of the type.

VII. Geoffrey of Monmouth's importance in the history of the political prophecy in England.

I. He introduced the type in The Book of Merlin.

2. He set the example for literary forgery of prophecies-Ganieda.

VIII. John of Cornwall's Seven Kings, another version of the same material as The Book of Merlin but independent of it. Comparison of the two prophecies. Some original Welsh phrases in the commentary.

IX. The Collection made by Giraldus Cambrensis-altogether different from the material in the Book of Merlin-Giraldus claims to have translated from the Welsh. 


\section{xiii}

\section{CHAPTER II}

The Sources of The Book of Merlin

I. Warning that the question of the sources of The Book of Merlin must be kept distinct from the question of the lost 'British Book.'

II. The material in The Book of Merlin was new to England-political prophecies in England antedating it.

I. Saints' Visions.

2. The Omen of the Dragons from Nennius.

3. The Vision of Edward the Confessor.

III. The Book of Merlin was not a continuance of local tradition-the source must be sought elsewhere.

I. Brandl's theory that Geoffrey forged.

2. Geoffrey's own statement that he translated from the Welsh. IV. Refutation of Brandl.

1. Examination of The Book of Daniel and the $X V$ Signa ante Judicium which Brandl names as models for The Book of Merlin.

2. Other possible sources.

a. Biblical prophecies-cursory treatment to show that there is little or no resemblance.

b. Classical prophecies-the same manner of treatment except in the case of the Oracula Sibyllina-more detailed mention because the Sibyllic prophecies are all derived from this collection.

c. Early medieval prophecies.

I. Traditional themes growing out of the Oracula Sibyllina.

a. The end of the World.

b. Fifteen Signs before the Judgment.

c. Anti-Christ.

d. The Last King of Rome.

I. Methodius.

2. Adso.

3. Appearance of the same prophecy in England.

2. Continuance of the Sibyllic tradition in the West-the

Prophecy of Sibyl Tiburtina.

3. Animal prophecies preceding The Book of Merlin.

a. The Vision of Childerich.

b. The Anchorite's Vision. o $\mathrm{V}$ - ijuant

c. The Vision of the Five Beasts.

3. Conclusion-The peculiar characteristics of the Galfridian type were not affected by the Classical, Biblical, or Sibyllic prophecies, though Geoffrey himself must have known a good part of the material. His refusal to copy it must have been deliberate. He could at most have got only a suggestion from the last three prophecies discussed. Such a point would be 
difficult to prove. Time to consider the evidence in behalf of Geoffrey's own statement.

V. Geoffrey's own statement supported.

I. Reasons for not taking Geoffrey's statement unsupported.

a. Reputation for mendacity incurred by the failure of scholars to find Archdeacon Walter's 'British Book.'

x. Remarks of William of Newburgh in this connectionso far as the prophecies are concerned William admits that Geoffrey translated from the Welsh-real import of William's remarks shown in a footnote-his chief anger is directed against the Welsh for perpetuating the Arthurian myths.

2. Although the British Book has not yet been found scholars no longer insist that Geoffrey forged his material, but admit that he had some source-Geoffrey not the first to associate Merlin with the Arthurian story-the name Merlino in Italy in the IIth century -Godfrey of Viterbo and Geoffrey compared in footnote.

2. Evidence in behalf of Geoffrey's statement.

a. External evidence.

x. William of Newburgh.

2. John of Cornwall's independent version of the same material translated from a Welsh original.

3. Collection made by Giraldus from Welsh originals shows that similar material existed in Welsh.

$b$. Internal evidence.

r. Merlin a prophet in Welsh predictive poems.

2. The Cadwalader-Conan episode common to the Welsh poems and The Book of Merlin.

3. The resemblance between the animal-symbolism in The Book of Merlin and the animal-epithets of Welsh poetry. The animal-epithet shown to be as old as Gildas (details in note). This point is treated in detail as furnishing very strong evidence.

c. Conclusion-the evidence points to Welsh origin.

\section{CHAPTER III}

The Major Monuments of the English Tradition: Scottish, Welsh, AND Irish Prophecies

I. The Six Kings to follow King John.

r. History 'of the prophecy-comes from material in The Book of Merlin-details to be studied in an appendix.

2. The prophecy paraphrased.

II. The Prophecy of John of Bridlington. 
I. Authorship-unknown, attributed to John of Bridlington.

2. Date (1362-1364) how arrived at-internal evidence-issue taken with Thomas Wright.

3. The plan of the prophecy-contents of the introductory essays.

4. Conventions observed in writing the prophecy-symbols are few -translation of a typical passage.

5. Relation of the poem to other prophecies.

a. caput Martis-antedates Bridlington.

b. Earlier prophecies that contain Gallus as a symbol for France or for the King of France.

c. The Cock in the North-an adaptation of material taken from Bridlington with additions.

d. The Prophecy of the Fishes-metrical translation of a long episode from Bridlington.

III. The English Becket.

I. General description-seems to be a fragment of a longer poem.

2. Contents.

3. The two versions.

4. Relation to the Six Kings-at times rather close.

IV. The Erceldoune Cycle.

I. The romantic elements.

2. The prophecies.

3. The traditional material.

4. Relation to other prophecies.

a. The Harleian Erceldoune.

b. The Northumbrian Ballad (no better name).

5. The date of the poem.

Later than 88 - perhaps before August I400-Brandl's argument to place it 1400 shown to be unsound-his interpretation of the symbols faulty and inconsistent.

6. Authorship-unknown.

Note on the real Thomas of Erceldoune-no evidence that he ever produced anything beyond weather predictions-issue taken with Murray.

V. Scottish prophecies.

r. Latin prophecies relating to Scottish affairs.

2. The Whole Prophesie of Scotland, a collection-chief attention given to

a. The Cock in the North-Brandl's interpretation unsatisfactory-mention of the following:

b. Bertlington.

c. Rymour.

$d$. The Sibyl.

VI. Brief notice of Welsh prophecy after Geoffrey of Monmouth.

VII. Passing review of Irish prophetic material-nothing of importance. 


\section{xvi}

\section{CHAPTER IV}

\section{Relation of the Prophecies to Political Events}

I. Wide credence given secular prophecies in the Middle Ages.

II. Close relation of the prophecies to history.

I. The prophecies form a vaticinal chronicle of English history.

2. The prophecies most numerous in times of political crisis.

3. Re-interpretation of old prophecies.

a. Commentary on The Book of Merlin by Alanus de Insulis.

4. Fulfillment of prophecies constantly expected.

5. Enduring power of the prophecies as shown by the Giraldian Collection (c. I190-165I).

III. Classification of prophecies according to relation to political affairs.

I. Literary prophecies-those written merely as exercises to narrate history in terms of prophecy and to express the writer's own feelings, but with no intention of influencing opinion or the course of events.

a. Geoffrey's Book of Merlin and Prophecy of Ganieda.

b. Earlier versions of the Six Kings.

c. The English Becket, etc.

2. Propagandist prophecies-those written with the intention to influence opinion and to direct the course of events.

a. Mention of prophecies previously discussed.

I. Erceldoune.

2. I $5^{\text {th }}$ century version of Six Kings, etc.

b. Adam Davy's Dreams.

I. Contents.

2. Author-new material.

3. Date-original work-issue taken with O. F. Emerson.

c. Ampulla prophecies ascribed to Becket.

d. Prophecies in Lilly's Monarchy or no Monarchy.

IV. Actual influence exerted on political history by prophecies.

I. Direct evidence.

$a$. The Tripartite Convention.

b. Welsh Rebellion against Henry VIII.

2. Indirect evidence.

a. Testimony of Chroniclers.

$b$. Laws passed against the dissemination of Prophecies.

I. Two laws by Henry IV.

2. Henry VIII.

3. Edward VI.

4. Elizabeth.

c. Violations of these laws-two instances discussed. 


\section{xvii}

\section{CHAPTER V}

The Development and the Decline of the Political Prophecy

I. Change in language used in the prophecies.

I. Earliest prophecies were in Latin, but Latin prophecies were used even to the end of the sixteenth century.

2. A few prophecies appear in French-either translated into Latin or some English dialect.

3. Prophecies in the vernacular-the Here-prophecy as early as I I90.

II. Annotations and commentaries on prophecies.

III. Re-writing and re-working of older material.

IV. No particular literary form ever came to be recognized as best suited to vaticinal expression.

I. Prose prophecies.

2. Verse prophecies-various kinds of verse forms used.

V. Change in the use of symbols.

I. Arbitrary symbols-in the earlier prophecies the symbols were chosen arbitrarily-perhaps some metaphorical significance at the time.

2. Traditional and conventional symbols-originally arbitrary-Edward the Second is always the Goat.

3. Heraldic-after the rise of heraldry men were frequently spoken of by the names of the animals that appeared in the coatarmor.

4. Several kinds of symbols may be used in one and the same prophecy-The English Becket, etc.

VI. Prophecies other than the Galfridian in England.

I. Sibyllic Prophecies.

a. H. patre.

b. Hempe.

The method was never applied in England as on the Continent.

2. Prophecies which show a combination of the Sibyllic and Galfridian types.

Six Letters to Save Merrie England.

3. Freak Prophecies.

a. Dice prophecies.

"When six shall up and sink (cinque) shall under."

VII. Change in the narrative style.

I. Purely symbolic prophecies-in The Book of Merlin the action is told entirely by the use of animal symbols.

2. Straightforward narrative with no ambiguity.

a. Here.

b. Pseudo-Grebner, etc.

3. Straightforward in parts, symbolic in parts.

The English Becket. 


\section{xviii}

4. Rhetorical prophecies-in which the desired amount of ambiguity and obscurity is gained without recourse to symbols but by the use of metaphorical, figurative, and highly-colored language. The Scottish Merlin, as quoted by Lilly.

5. Paradoxical prophecies-

Harleian Erceldoune.

6. Prophetic pictures-quite a common class.

Lilly's pictures in Monarchy or no Monarchy-relation to the Six Kings.

7. Decadent prophecies of the seventeenth century.

William's Prophecy quoted in a note as a fair example of the absurd kind.

VIII. The decadence of the prophecy-

I. Growing popularity of astrology which gradually supplanted the prophecy.

a. Annual prognostications.

b. Almanacs.

2. Adverse legislation-previously discussed.

3. Growing freedom from superstition.

4. Opposition on the part of men of influence and scholars.

a. Bacon.

b. Earl of Northampton.

c. John Spencer.

5. Ridicule of the type by means of parodies and burlesques.

a. Piers Ploughman-2 instances.

b. "When Asses grow Elephants," by Sir John Harington.

c. Shakspere in Lear.

$d$. Dekker in The Raven's Almanac, etc.

IX. Influence of the type on English Literature.

I. The same method of narration used by Greene in James the Fourth.

2. Custom of using a man's heraldic emblem for the man.

a. James Howell-Fables.

b. Gower in Cronica Tripartita.

c. Skelton.

d. Spenser, etc.

3. Convention of introducing prophecies into epics-borrowed from Italy (Ariosto).

a. Spenser-Merlin from the Cave in the Faery Queen.

b. Milton-Michael from the Mount in Paradise Lost.

$\mathrm{X}$. Summary of main points in the preceding chapters.

I. Geoffrey's importance.

2. Welsh origin of the Galfridian type of prophecy.

3. Major monuments.

4. Historical relations and political influence of the type.

5. The flowering time and causes for the decline. 


\section{xix}

\section{CHAPTER VI}

The Galfridian Type of Prophecy in Other Countries than England.

I. The way prepared for Geoffrey by Nennius and the Omen of the Dragons, and by the early forms of the Arthurian legend.

II. Quotations from The Book of Merlin by Continental writers of I 2 th and I $3^{\text {th }}$ centuries.

I. France.

$\checkmark a$. Ordericus Vitalis.

b. Geoffrey de Breuil.

c. Alanus de Insulis.

d. Suger, etc.

2. Italy.

The evidence is chiefly indirect-

a. Great popularity in $13^{\text {th }}$ century points to some knowledge of the material in the twelfth century.

b. English soldiers of Richard the First's army could easily have spread the material.

c. Prophetic material known in Provence in twelfth century, and could easily have crossed into Italy with other Provençal literature.

3. Germany and Iceland-mention-scanty material.

4. Dissemination of the twelfth and thirteenth century manuscripts-some perhaps to these countries as early as the twelfth century (note).

III. Translation of The Book of Merlin.

I. Iceland-Merlinus Spa. I 2 th century.

2. Indirect evidence for German, Dutch, and Provençal.

3. Waurin's 15 th century French version in a Chronicle of British Kings.

a. Description of contents.

b. Date.

IV. Local prophecies of European countries attributed to Merlin and written according to the Galfridian conventions.

I. France.

a. Fragments in chronicles.

b. Richard of Ireland's collection.

c. Echoes in Deschamps' poems.

2. Italy.

a. Hugh of Bariol and Peter of Apulia.

b. Joachim.

c. Miscellaneous I $3^{\text {th }}$ century prophecies ascribed to Merlin.

V. Galfridian prophecies on the Continent attributed to other prophets than Merlin-a direct borrowing from England since the native Continental type was the Sibyllic.

I. Germany.

John of Toledo. 
2. France.

a. Prophecies quoted by Deschamps.

b. Profetie d'Orval.

c. Epistre de Sibille.

3. Italy-discussion confined to $13^{\text {th }}$ century prophecies because the wealth of material is embarrassing.

a. Sibyl Erithrea-pure Galfridian despite the name-detailed account of the contents.

b. Sibyl Samia.

c. Michael Scotus.

VI. The Continental Collection, ascribed to Merlin-contains prophecies of all kinds that have been described-themes belonging to many collections and to many countries-contains material of the twelfth, thirteenth, fourteenth and fifteenth centuries in dialog form.

I. Two versions-

a. French by Richard of Ireland.

b. Italian of the fourteenth century.

2. Origin-

Each Ms. tells a different story-Sanesi considers it Italian.

3. Quoted by Robert of Brunne in England.

VII. Interchange of prophetic material.

I. English prophecies known on the Continent and used there.

a. Deschamps-l'âne pesant.

b. Six Kings.

c. Foreign prophecies dealing with English affairs.

Unicornus de occidentali plaga.

2. Foreign prophecies known in England.

Brief and scanty mention.

VIII. History of the type on the Continent-the same phenomena of development and decline.

r. False attribution-professional prophets.

2. Opposition to the prophecies.

a. Decree of the Council of Trent.

$b$. Laws of Henry the Third of France.

c. Montaigne's Essay on Prognostications.

IX. Popular religious prophecies-brief mention-two recurrent themes:

I. The Returning Hero who should be a political Savior.

a. Arthur.

b. Barbarossa.

c. Sebastian of Portugal.

2. The Last King of Rome. 


\section{THE POLITICAL PROPHECY IN ENGLAND}

\section{CHAPTER ONE}

The introduction of the political prophecy into England with Geoffrey of Monmouth's Book of Merlin; Other prophecies of the twelfth century in England.

The political prophecy as a type of English literature has thus far received little attention. Nothing has been written on the subject as a whole except a few general statements based on hasty generalizations and insufficient acquaintance with the material. Passing references to the prophecies are made in the various manuals and histories of English literature.

Only a few of the prophecies have been edited. ${ }^{1}$ Most of

${ }^{1}$ The bibliography of the subject is very slight. The following books and articles exhaust it except for general remarks in manuals of literary history, and references in various treatises.

A. Brandl, Thomas of Erceldoun, Berlin, 1880 .

The Cock in the North. Poetische Weissagung auf Percy Hotspur, in Sitzungberichte der Königliche Preussichen Akademie der Wissenschaften, Berlin, 1909, pp. I I60-1 I89.

James A. H. Murray, The Romance and Prophecies of Thomas of Erceldoune, London, I875, E. E. T. S., 6r.

F. J. Furnivall, Adam Davy's Dreams about Edward the Second, London, 1878. E. E. T. S., 69.

J. Rawson Lumby, Some Early Scottish Prophecies, in Bernardus de Cura rei familiaris, London, I870. E. E. T. S., 42.

A. Schultz, Die Sagen von Merlin, Halle, 1853; discusses the early prophecies attributed to Merlin and prints the Vita Merlini.

W. E. Mead, Various Forms of the Merlin Legend, in Merlin, Vol. I, London, I899. E. E. T. S., I0, II2.

H. de la Villemarqué, Myrdhin, Paris, I862, discusses the early use of Welsh prophecies and touches on the question of Merlin as a prophet. As Villemarqué is not very reliable, his statements must be carefully verified.

Thomas Wright, John of Bridlington, in Political Poems relating to English History composed during the period from the accession of Edward 
those that have been printed are hidden away in appendices and notes to other books. The difficulty in the way of a thorough study of the field and the different monuments lies in the fact that most of the material necessary for such study is yet in manuscript form and is inaccessible to many students. Until this material is carefully sifted and studied in detail it is unwise to attempt absolute and final pronouncement on any part of the subject. The purpose of this present study, therefore, is to set forth the facts as they have been gleaned from the material available, and to serve as a general introduction to the whole field.

The term political prophecy needs no explanation as to its general import. Everyone will understand it as applying to any expression of thought, written or spoken, in which an attempt is made to foretell coming events of a political nature. For the purposes of study from the point of view of literary history, however, it is necessary that the prophecies be written in some literary form. This presupposes an existence beyond the immediate time of composition; for oral prophecies, as a rule, are given on the spur of the moment, and therefore are temporary in that they, concern matters of immediate import, the outcome of which is near. Such prophecies as that delivered by Peter of Pomfret do not meet this requirement and therefore do not enter into consideration here. This requirement, however, does not preclude the oral transmission of written prophecies, or the composing of oral prophecies according to the conventions of the written form. Moreover, the prophecies when written must observe the ordinary conventions of narrative writing; the usual literary political prophecy reads very

the Third to that of Richard the Second, Rolls Series, 2 vols., London, I859-6I, xxix-liv, I23-215.

Ancient Scotch Prophecies, Bannatyne Club Publications, 44, Edinburgh, I833. Merely a reprint with no editorial comment.

H. L. D. Ward, Catalogue of Romances in the British Museum. Vol. I, pp. 203-338, contains a description of several prophecies that have not yet been printed, and has proved of great assistance in the course of this study.

No mention is made here of those prophecies that have been printed in notes and appendices to other books without any editorial comment. Such information is given in the notes as each prophecy is mentioned. 
much like history written in the future tense. Accordingly, the show of kings in Macbeth is not to be regarded as belonging properly to this study, for it observes the rules of dramatic exposition, not of narrative composition. Prophecies, however, may be quoted by characters in a play; Peele's Edward the First, for instance, abounds in them.

Literary political prophecies differ very much in the manner in which the vaticination is delivered. If the events are foretold simply and directly without any attempt to disguise them and to make the description obscure, the method may be called direct. The language may be figurative and obscure, but the main issue remains clear. This is the usual method of the Biblical prophecies. An excellent example is Isaiah's prophecy against Damascus: ${ }^{2}$

"Behold Damascus is taken away from being a city, and it shall be a ruinous heap.

"The Cities of Aroer are forsaken: they shall be for flocks, which shall lie down, and none shall make them afraid."

But the desire for obscurity and ambiguity frequently leads to the adoption of certain disguises for the characters in a prophecy. A vaticinal method in which such devices are used may be called symbolical. For instance, "The Ass of Wickedness shall succeed, swift to fall upon the workers of gold but slow against the ravening of wolves."3 Most of the secular prophecies are symbolical, though the language employed is itself usually bare of ornament.

The prophetic symbols used are not always the same, and therein lies another difference. The European prophecies earlier than the twelfth century use one kind of symbols, the English prophecies use another. In the European prophecies the author was content to use only the initials of the characters with whom he was dealing. This method may be called Sibyllic, for it first appears in the celebrated Oracula Sibyllina.

2 Isaiah, I 7 ; I-2.

${ }^{3}$ From the Prophecy of Merlin in Geoffrey of Monmouth's Historia Regum Brittaniae-textual edition, ed. J. A. Giles, London, I844, p. I24; most recent translation by Sebastian Evans, Temple Classics, London, I904, p. I78. 
The most distinctive feature of the English method is the use of animals and birds instead of men and women. An English prophecy containing this peculiar symbolism reads very much like some animal story. There is, however, this difference; the animals are constantly felt to represent individual men and women who are never lost sight of behind the mask, even if their identity is unknown. This amounts, really, to little more than giving animal names to men and women. This vaticinal method may be called the Galfridian, for it is used extensively for the first time by Geoffrey of Monmouth in The Book of Merlin. Other symbols are used in it, but they can best be observed in the progress of the study.

The reign of Edward the Second is thus described in one of the prophecies written when the genre was in its most flourishing period: $:^{4}$

"And after this dragone shal come a gote out of a Kar, bat shal haue hornes \& berde of siluer: and bere shal come out of his nosebrelles a drop bat shal bitoken hunger \& sorw, \& grete deb of be peple: and miche of his lande in be beginning of his regne shal be wastede. This goot shal go ouer into Fraunce, \& shal oppon the floure of lif and of deb. In his tyme bere shal arise an Egle in Cornewaile bat shal haue feperes of golde, pat of pride shal be wipouten pere in all be lande: and he shal despise lordes of blode: and after, he shall flee shamefully by a Bere at Gauersiche: and after shal bene made brigges of men oppon be costes of be see: and stones shal fall fram castelles, and meny opere tounes shal bene made pleyne: and a bataile shall bene done uppon an Arme of be see in a felde ordeynede as a shelde: and at bat bataile shal dye meny white hedes: wherfore bat bataile shal bene callede 'be white bataile.' And the forsaide Beere shal done bis goote michel harme, and it shal bene oute of be Soupwest .... ; and he (the Goat) shal avenge him oppon his enemys, brouz conseil of ij oweles, bat ferst shal bene in peril forto bene undone: but be olde owel shal wende ouer be se into a straunge lande, and bere he shal duelle unto a certayne tyme: and after, he shal come azeyne into bis lande ... : and at be last, be goot and be oweles shullen come atte Bur up Trent, and shullen wende ouer: and for drede, be Bere shal flee, and a swan wib him, for his company, to Bur towarde be North, $\&$ bere bai shal bene wib an harde shoure. And ban be swan shal bene slayne wip sorwe, and be Beere taken \& beheuedede alber nexte his neste, bat shal (stand) uppon a broken brigge, up wham be sone shal caste his beemes: and meny shal him seche, for vertu bat from hym shal come. In bat tyme

${ }^{4}$ The Brut, E. E. T. S., I3I, ed. F. W. D. Brie, London, 1906, vol. I, p. $73 \mathrm{f}$. 
shal dye, for sorw and care, a peple of his lande, so bat meny shal bene oppon him be more bolder afterward. And bo ij owles shullen do miche harme to be forsaide floure of lif, and here shul lede in distresse, so bat she shal passe ouer into Fraunce, forto make pees bituene be gote \& be floure delice: and pere she shal duelle to a tyme bat her sede shal come to seche her: and bere bai shul bene til a tyme bat bai shul ham clobe wib grace: and bai shul seche the Owelyn, and put ham unto despitous deb. And after shal pis goot bene brouzt to disese: and in Grete anguisshe and sorwe he shal leve al his lif."

This use of animal-symbolism is unique. Animal figures occur in medieval allegory, such as the Questing Beast in Malory's La Mort D'Arthur, but they are personifications of abstract ideas. In the saints' visions fiends and demons frequently take the shape of beasts and monsters, and attempt to frighten the holy men with their hideous shapes and their terrible howling. Animals occur in the bestiaries and their supposed natural traits suggest moral reflections. The beast fable, also, employs animals; but there the animal, or bird, represents some type of man, and the story is told to bring out some truth of human nature. In all there is more or less tendency to abstractness; the figures in the beast fable are individual and concrete enough, but they are used to exemplify abstractions. In the prophecies every figure is individual and concrete without any trace of abstractness. The animal name is but a mask behind which the individual hides incognito. This concreteness and individuality of each figure is the peculiar and distinguishing characteristic of the symbolism.

It must not be supposed that the means of prophetic disguise were limited to a single method. On the contrary numerous devices were employed. What various tricks were used can well be realized from the commentator's account of those employed in the Prophecy of John of Bridlington. Ten methods in all are recognized, but some seem in large part repetitions of others. The first is the use of arbitrary names, by which is meant the adoption of certain arbitrary symbols. All the examples quoted are animal names. The second is accidental designation, or the use of names derived from some incident in the life of the individual referred to or from some peculiarity in manners, person, name, surname, or arms. 
William La Zouche is referred to by the Latin word, suspicor, and Lord Percy as penetrans. Both instances are merely puns on the names. The third method the commentator calls equivocation, the use of equivoque or ambiguity. For instance, the word cancer may stand for the crab, for the Sign of the Zodiac so-named, or, according to the first method, for the King of Scotland. The fourth is the use of metaphor, as when ships are spoken of as horses and their rigging as bridles. The fifth is the use of words made from Roman numerals; letters which stand for a numerical expression are so combined as to form words, such as Milvij which stands for MLVII, or Cuculi which stands for CCLXI. The sixth method is etymologized translation, by which is meant the translation of the component parts of an English compound word. Thus Herthford becomes terra vada and Mortimer mare mortis. The seventh is the use of enigma, and can best be understood by quoting. The line, Si quis taurum, caput amputat, inde fit aurum (if anyone cuts off the head of a bull, gold is made thereby) affords an excellent example. The amputation is not to be performed on the bull but on the word taurum, and the word aurum results. The eighth is the division of words, and is fortunately of rare occurrence, for it only adds to confusion worse confounded. A word is introduced between the parts of another word that should follow or precede it. ${ }^{5}$ The ninth is the use of ambiguous words. The tenth is simply abbreviation.

The ten devices just described, all of which are used in The Prophecy of John of Bridlington, make up a very elaborate scheme of prophetic composition. Not all are used at the same time in the other prophecies. The first, which amounts to the use of animal names, is most frequently employed. The other devices are used variously, some in one prophecy, some in another. The vision machinery is occasionally employed, as in The Dreams of Adam Davy about Edward the Second, without these various tricks of disguise and without any ornament of style save obscurity of language.

Besides the various devices of disguise others were used to make the prophecies more credible. One of these was a com-

' Falsus non stabit, Phi et lippus fugitabit. (Bridlington II, v.) 
bination of fact and fiction, usually a characteristic of the more extensive monuments. The writer dated his prophecy earlier than the real time of composition and retold historical facts as a part of the genuine prophecy. The greater part of The Prophecy of John of Bridlington is a truthful account of historical events and the prophetic part is but a small portion of the whole. It was expected that the reader, finding the first part true, would consider the whole inspired and accept the last part as unquestionable. Furthermore, the prophecies were sometimes attributed to famous scholars of an older time, as in the case of Bede and Gildas; to popular saints as those of Thomas à Becket and John of Bridlington; or to men already reputed as prophets, as Merlin and Thomas of Erceldoune. The same prophecy is frequently attributed to various persons.

Such writing as has just been described was almost unknown in England before the twelfth century. Some episodes in the visions of the saints might be termed prophetic, but they were rarely concerned with political affairs and contained no animal symbols. St. Cuthbert, it is true, had foreseen in a vision the death of a king of Denmark. St. Dunstan had uttered a few prophetic sentences concerning Ethelred the Unready, but they were of a general nature and foretold no particular event. Exception to the general statement must be made, however, in the case of two productions before the twelfth century, the so-called Vision of Edward the Confessor and The Omen of the Dragons.

The Omen of the Dragons is a part of that mass of fiction that gathered about the Arthurian story. It belongs more properly to the Romance of Merlin, and is one of its oldest fragments. It is first told by Nennius. ${ }^{6}$ According to the story, Vortigern wished to build a tower on Mt. Heremus and got together material on the spot for it, but on three occasions what had previously been collected disappeared in one night. The king was advised by his wise men that before the foundations would stand, the spot would have to be sprinkled with the blood of a child born without a father. Messengers sent throughout the kingdom in search of the prodigy returned with Ambrosius.

- Nennius, 40-43. 
$\mathrm{He}$, however, on learning why he had been brought to the court told the King that his blood would be useless, and said that he would explain the phenomenon in another way. With the King's permission he commanded the pavement to be torn up, whereupon a pool containing two vases was disclosed. When the vases were opened a folded tent was discovered, in which were two sleeping serpents (or dragons), one red, the other white. The two dragons awoke and began a terrible combat which ended in the complete rout of the white dragon. Ambrosius interpreted the white dragon as the Saxons who had recently been introduced into the country, and the red dragon as the Britons. The contest between them typified the long struggle for supremacy, between the two peoples, and the victory of the red dragon meant the final triumph of the British.

The Vision of Edward the Confessor is not important, but it must be mentioned here as being an early example of vaticinal literature in England. It is first found in an anonymous life ${ }^{7}$ of Edward the Confessor dedicated to his widow, who died in I074, and occurs in all the redactions. It purports to have been delivered to the king by two holy men whom he had known in Normandy. It runs, "If a green tree is cut in the middle and the part lopped off is moved three jugera from the stem, when the part moved away shall of its own accord and without the aid of any human hand unite itself to the trunk and begin to flourish and bear fruit, then for the first time can a respite from such great evils be hoped for."'s

The credit of really introducing the political prophecy into England belongs to Geoffrey. ${ }^{9}$ His three books, The Book of

${ }^{7} \mathrm{H}$. R. Luard, Lives of Edward the Confessor, Rolls Series, London, I 858 , p. 431 .

${ }^{8} \mathrm{~J}$. H. Ramsey in The Foundations of England, London, 1898, Vol. I, p. 502, gives an altogether wrong impression of this vision by mistranslating, although the Latin on the page of Luard's Lives to which he refers is plain enough. The Latin is, "tunc primum tantorum malorum sperari poterit remissio," which he translates, "then shall the end be."

- The known facts of Geoffrey's life are few. He was a nephew and foster son of Uchtryd, Archdeacon and later Bishop of Llandaff. The family was Welsh and, through the marriage of Uchtryd's daughter, Angharad, to Jorwerth ap Owen ap Caradoc, Lord of Usk, was connected with 
Merlin, the Historia Regum Brittaniae, and the Vita Merlini are each of great importance in English literature, but only the first and last concern this study.

The Book of Merlin has not come down to the present day. Its contents are only to be inferred from the fragments quoted by Ordericus Vitalis, and from the prophecies as they now stand in the Historia, where they form the seventh book. This book consists of four chapters: the first is a preface, or prolog, in which Geoffrey says that he suspended work on the Historia to make public an edition of Merlin's prophecies, being urged thereto by Bishop Alexander of Lincoln and others whom he does not name; the second chapter is a dedicatory epistle to Bishop Alexander; the third and fourth contain the prophecies. Obviously the preface was not a part of the original work, but the dedicatory epistle was.

The vaticinal matter does not begin at once with the opening of the third chapter. The Omen of the Dragons had been begun in the last chapter of the preceding book, but had been interrupted by the prolog and the epistle. It is resumed at the point where the dragons awake and begin their combat. The King requests Merlin to explain the portent of the dragons. Merlin obeys and gives much the same account as had appeared

one of the princely families. It is conjectured from Geoffrey's signatures that his father's name was Arthur. His family and his patrons, Bishop Alexander of Lincoln and Earls Robert and William of Gloucester, all belonged to the party of the Empress Matilda. His name with that of his friend, Archdeacon Walter of Oxford, is signed to three documents, the first in 1129 , the others in 1138 . His Book of Merlin, as will be shown later, was produced before December, 1135. The first recension of the Historia, now lost, was produced as early as II 39. In February, II 52, he was ordained priest and consecrated Bishop of St. Asaph's. He died at Llandaff in II54, apparently without ever entering upon his bishopric. He was evidently a member of the Norman party among the Welsh. His family must have been of prominence to have obtained such preferment as was given him and his uncle. Geoffrey himself was known to men of power and influence, and may have been in touch with courtly circles.

For the known facts consult Ward, Catalog of Romances, vol. 1, p. 203, and Anglia, $X X I V, 383$. For a different view as to the early date of the Historia, consult R. H. Fletcher, Two Notes on the Historia Regum Brittaniae of Geoffrey of Monmouth in Publications of the Modern Language Association, Vol. 16, p. 461-474. 
in Nennius's version, but he goes further and prophesies the future of Britain until the end of the world. After a period of oppression the Britons (the Red Dragon) prevail under the leadership of 'The Boar of Cornwall' (Arthur). Historical events, actual or legendary, up to the time of the Norman Conquest are described briefly and indefinitely, and with little symbolism. During this period 'the German Worm' rises again with the aid of 'the Wolf of the Sea,' religion is 'done away with,' famines and various misfortunes befall the chosen until 'he that shall clothe himself in the brazen man' brings them assistance, a 'Blessed King' fits out a navy, a second period of desolation and a second German invasion follow, and finally vengeance comes upon the 'German Worm' for his treason. Then follows the coming of the Normans, which is referred to as 'the decimation of Neustria.'

A more detailed account of events begins with the reference to the Norman Conquest. Thereafter the animal-symbolism, which had been used sparingly, is the regular form of expression. After William the Conqueror, who is mentioned very indefinitely, 'two dragons' (William the Second in England, Robert the Second in Normandy) succeed, of whom one is slain by the arrow of envy and the other returns under the shadow of a name. ${ }^{10}$ Then the 'Lion of Justice' (Henry the First) succeeds. The various events of his reign are described figuratively. After him seems to come a King Sextus, but there is no preparation for the numbering. ${ }^{11} \mathrm{He}$ is succeeded by the 'Lynx,' under whom the Normans lose their power and the kingdom reverts to the descendants of Brute, the rightful owners. The overthrow of the Norman power is thus foretold: $:^{12}$

"Of him (Sextus) shall issue forth the Lynx that seeth through all things, and shall keep watch to bring about the downfall of his own race, for through him shall Neustria lose both islands and be despoiled of her

${ }^{10}$ Evans, p. I75; Giles, I 20-121.

11 "Thence forward from the first unto the fourth, from the fourth unto the third, from the third unto the second the thumb shal be rolled in oil. The sixth shall overthrow the walls of Hibernia and change the forests into a plain." (Evans, 176; Giles, I22.)

12 Evans, p. 176; Giles, 122-123. 
ancient dignity. Then shall the men of the country be turned back into the island for that strife shall be kindled among the foreigners. An old man, moreover, snowy-white, that sitteth upon a snowy-white horse shall turn aside the river Periron and with a white wand measure out a mill thereon. Cadwallader shall call into Conan, and shall receive Albany into fellowship. Then shall be slaughter among the foreigners: then shall the rivers run blood: then shall gush forth the fountains of Armorica and shall be crowned with the diadem of Brutus. Cambria shall be filled with gladness and the oaks of Cornwall shall wax green. The island shall be called by the name of Brutus and the name given by the foreigner shall be done away with."

Much the larger portion of the prophecy follows the passage just quoted, but, since it defies interpretation and is too long, it must be passed over here. Attention should be called, however, to the closing passage, which is very curious. It is a description of the end of the world expressed in astrological terms. A short quotation will suffice to show the character of the whole. $^{13}$

"Stillbon of Arcady shall change his shield, and the helmet of Mars shall call unto Venus. The helmet of Mars shall cast a shadow, and the rage of Mercury shall overpass all bounds. Iron Orion shall bare his sword. Phoebus of the ocean shall torment his clouds. Jupiter shall trespass beyond his appointed bounds, and Venus forsake the way that hath been ordained unto her. The malignity of Saturn the star shall fall upon the earth with rain of heaven, and shall slay mankind as it were with a crooked sickle. ... The tail of the Scorpion shall breed lightnings, and the Crab fall at strife with the Sun. The Virgin shall forget her maiden shame, and climb up on the back of the Sagittary. The chariot of the Moon shall disturb the Zodiac, and the Pleiades shall burst into tears and lamentations."

These prophecies of Merlin are to be considered as a collection rather than as a continuous whole. A careful reading of them reveals a repetition of certain motives, each with the slight variations that are to be expected in contemporary versions of the same material. One that occurs not infrequently is a combat between a man and a dragon, in which the man climbs upon the dragon's back and vanquishes it.

"But a giant of iniquity shall arise that shall daunt all by the keenness of his eyes. Against him shall rise up the dragon of Worcester, and shall

${ }^{13}$ Evans, I 88 ; Giles, I 29-1 30. 
strive to bring him to naught. And in the battle shall he prevail against the Dragon, who shall suffer oppression under the wickedness of the conqueror. For he shall mount upon the Dragon, and putting off his garment shall sit upon him naked. The Dragon shall bear him aloft, and swinging his tail shall beat him upon his naked body. Then shall the Giant, again renewing his strength, pierce his gullet with his sword, and at last shall the Dragon die poisoned, entangled within the coils of his tail. After him shall succeed the Boar of Totness."14

Only six lines further begins the confused account of a struggle seemingly between dragons and men. Towards the close occurs the same motive: $:^{15}$

"A fifth shall succeed unto them that are slain, and by various devices shall break the residue in pieces. Upon the back of one shall he climb with a sword and sever his head from his body. Then, putting off his garment, shall he climb upon another and grasp his tail with his right hand and his left, for naked shall he vanquish him against whom when clad he might nought prevail. The rest shall he torment and drive them all the kingdom round."

\section{Further a similar motive occurs: $:^{16}$}

"Then shall two follow the sceptre, unto whom shall the horned Dragon minister. The one shall come in iron, and upon a flying serpent shall he ride. With his body naked shall he sit upon his back, and with his right hand shall he lay hold of his tail."

These passages relating to the dragon are all worked into the context with some appearance of continuity, which may, however, be due to the care either of the original compiler or of the translator himself. Other recurring motives are the nesting of birds, periods of moral depravity, famines, and pestilences. Similar groups of related passages are to be found. For instance, the motive of the tree with the three branches ${ }^{17}$ resembles very much in form the motive of the three Fountains of Winchester, ${ }^{18}$ but the details of the two are different. Certain animal symbols recur as if they are to be applied to the same person. The 'Ass of Wickedness' at the end of the third

\footnotetext{
${ }^{14}$ Evans, 184; Giles, 127.

${ }^{15}$ Evans, 185 ; Giles, 128.

16. Evans, I86; Giles, I 29.

${ }^{17}$ Evans, 178 ; Giles, 123.

${ }^{18}$ Evans, I79; Giles, I 24.
} 
chapter may also be the 'Ass' that calls to the 'Goat with the long Beard' in the next chapter. The whole body of the prophecy is made up of what might be called episodes which vary in length from one to several sentences. Each episode could be separated from the context and circulated as an independent whole with very little loss of meaning. Such separation and independent circulation did in fact take place, as fragments quoted not only by writers in England but also by writers in other countries show. It was of such fragmentary bits that the original was probably put together.

The date of The Book of Merlin is uncertain. Internal evidence, contrary to what one would expect, furnishes little assistance. At first sight the student is tempted to interpret portions of the prophecy in terms of his own later knowledge, to assign a date for them, and to credit Geoffrey with them because the interpretations fit so well. But one must be on his guard against such hasty interpretations, for they are frequently incorrect. For instance, the passage, "Albany shall be moved unto wrath, and calling unto them that are at her side shall busy herself in the shedding of blood," 19 would seem to refer to the Battle of the Standard, which was fought in II37. But such cannot be the case, for this passage occurred in the original Book of Merlin and, as will be shown later, must have been written before December, II35. A passage in the Sextusepisode, "Two cities shall he robe with two palls," explained as referring to the creation of new bishoprics by Henry the first, Ely in IIO9 and Carlisle in II33. But the passage occurs too late in the context to be given such interpretation. The last historical event that can be identified with certainty is the drowning of Henry's children in the disaster of the White Ship in I $120 .{ }^{21}$

${ }^{19}$ Evans, 176; Giles, r22. This passage must be a fragment coming down from the time of William the Conqueror or from earlier conflicts between the Britons of StrathClyde and the Scots. It cannot belong to the time of Henry the First, for perfect peace existed between England and Scotland during his reign.

${ }^{20}$ Evans, x76; Giles, $x 22$.

21 "The Lion's whelps shall be transformed into fishes of the sea." Evans, I75; Giles, I22. 
The most concrete piece of evidence bearing upon the date of The Book of Merlin is external. Ordericus Vitalis in his Historia Ecclesiastica ${ }^{22}$ quotes from a book he calls Libellus Merlini a long passage which is almost identical with a portion of the prophecies as they stand in the Historia of Geoffrey. The chapter in which this long quotation occurs must have been written before the death of Henry the First in December, I 35, for it contains a reference to him as being King of England. The Libellus Merlini, or The Book of Merlin, must therefore have been written after II 20 and before the end of II35. It is presumed to have been an edition of the prophecies alone. Its size may be surmised from the fact that the part quoted covers in the text of the Historia a page and a half octavo, ${ }^{23}$ and is called by Ordericus "brief extracts from Merlin's book." The quotation begins with the coming of the Normans, "A people in wood, and jerkins of iron," and ends with the accession of the 'Lynx,' who is called 'The Pest' because of a manuscript reading lues for lynx.

The Libellus Merlini from which Ordericus quoted evidently differed somewhat from the version of the prophecies in the Historia. It seems to have been provided with a commentary, or interpretation, at least for some passages, echoes of which occur in Ordericus's application of the 'Decimation of Neustria' to the massacre of Prince Alfred and his attendants at Guilford, and in the explanation given for the passage, "Two dragons shall succeed." These interpretations may, however, be original with Ordericus; for at the close of the chapter he says that he does not intend writing a commentary on Merlin, but that he could if he chose. The Libellus may have begun with the Omen of the Dragons, as this story is told in indirect discourse by Ordericus immediately before he quotes directly from the prophecies. The fact that Ordericus changes the colors of the dragons shows that he was not quoting from Nennius, to whose work he had referred the reader in the preceding paragraph. His original, however, was closer to the version of Nennius than that which is found in the Historia,

${ }^{23}$ Historia Ecclesiastica, Book 12, cap. 57.

${ }^{23}$ Giles, I 2 I-I 22. 
for Ordericus frequently uses the same words as occur in Nennius's account but which are not found in the Historia. The lynx-lues difference between the Libellus and the Historia has been mentioned. Other differences occur, but they are of minor importance. The passage, "Woe unto thee, Neustria, for the brain of the Lion shall be poured upon thee," is omitted, ${ }^{24}$ but it is a late interpolation in the Historia.

Geoffrey of Monmouth's third book, the Vita Merlini, ${ }^{25}$ is important in this study for two prophecies it contains, one delivered by Merlin, the other by Ganieda. It deals with the life of Merlin and contains details so different from those given in the Historia that legends of two Merlins arose, one the Ambrosius Merlin of the Historia, the other Merlin Silvester, or Caledonicus. All this is very interesting and important in the history of the Merlin Romance, but the Romance is not the subject of this study. Details relating to it must, therefore, be omitted.

The prophecy of Merlin in the Vita covers the period from the reign of Maelgwyn past Geoffrey's own time into the reign of Sextus and stops where the most symbolic part of The Book of Merlin begins. ${ }^{26}$ For the ground covered it goes into greater detail than the earlier prophecy, but contains few animal symbols. Some symbols are common to both prophecies, such as the 'Boar of Cornwall' and the 'Wolf of the Sea.' There is also occasional repetition of motives, such as the girdling of men with the teeth of animals. Much of the prophecy is merely veiled allusion, and could have been composed by Geoffrey himself. There is apparently more reflection of actual history in the passages referring to the attacks of the

${ }^{24}$ This passage refers to the embalming of Henry the First's body. Evans, I75; Giles, I22.

${ }^{25}$ For a discussion of the authorship, which has been disputed, see Ward, loc. cit., Vol. I, p. 278. This new work is dedicated to Robert de Chesney, Bishop of Lincoln after the death of Geoffrey's former patron, Bishop Alexander. After the death of his earlier patrons Geoffrey needed a new one, and chose one in touch with the court of Stephen.

${ }^{26}$ Line $58 \mathrm{r}$ to line 680 . Geoffrey may have stopped here from prudential motives, for by doing so he omitted the prophecy on the overthrow of the Normans. 
Scots on the Britons, to the destruction of the cities, and to the assumption of arms by prelates. But beyond this closer relation to history there is nothing of real importance in it so far as the history of the type is concerned. It does not profess to be a translation of another Welsh version of the material, and there is no reason to consider it as such. It is perhaps only a re-working of old material by Geoffrey himself with some additions and interpolations of vaticinal fragments not contained in the Book of Merlin.

The Prophecy of Ganieda, ${ }^{27}$ though shorter, is much the more important of the two so far as the history of the genre is concernied. In it actual history is written as prophecy in accordance with the conventions of the Galfridian type. The events described occurred in the war between Matilda and Stephen. Two 'Lions,' two 'Moons,' and an 'Armorican Boar' wage one battle; another is fought between 'Stars' and 'Wild Beasts.' This application of the Galfridian conventions to actual history purely as a literary exercise, independent of any real prophecy, is an early modification of the original type. It set an example that was frequently followed in the succeeding centuries.

Shortly after the death of Geoffrey of Monmouth there appeared another version of the same material which he had used in The Book of Merlin. This was The Prophecy of Ambrosius Merlin concerning the Seven Kings, ${ }^{28}$ a Latin poem in one hundred and thirty-nine hexameters accompanied with a dedicatory epistle to Robert de Warelwast, bishop of Exeter, at whose request the poem was written. It purports to be a literal translation from the Welsh. Several Welsh place-names and phrases are quoted in the accompanying commentary; in three places ${ }^{29}$ they seem to have stood in the original. In the commentary references are made to historical events up to the accession of Henry the Second in December, II54, after an interregnum of six weeks, which is also referred to in the

${ }^{27}$ Line 1474 to line 1518 .

${ }^{28}$ Printed, Carl Greith, Spicilegium Vaticanum, Frauenfeld, I838, p. 99 f ; also, Viilemarqué, Myrdhin, p. 4I 7.

${ }^{29}$ Lines $18,65,92$. 
seventieth line of the poem. The reference in the commentary to Prince William, Henry's oldest son, helps to fix the date as I 55 , for the child died in the early months of I 56 . The translation is attributed, in the dedicatory epistle, to John of Cornwall, a rather prominent scholar of the time, who was credited with a knowledge of Welsh. ${ }^{30}$

The author passes over the history of the island before the Norman Conquest, saying, in his dedication, that this earlier material can be found well set forth elsewhere. He begins his poem with the coming of the Normans and ends it with their expulsion and the restoration of the Welsh. Between these limits the material is much the same as in The Book of Merlin. The same symbols are used in both except the 'Boar' for Henry the Second, a symbol not used by Geoffrey. At first glance there seems little difference between the two versions, for they cover the same ground and use practically the same material, but a careful comparison of them shows certain differences.

In The Book of Merlin the prophecy is pure narrative; in The Seven Kings it is in the form of question and answer. ${ }^{31}$ There is a bare suggestion of this in the Vita Merlini where Merlin delivers his prophecy in response to a question from Ganieda. The narrative portion of The Seven Kings is frequently interrupted by apostrophes, addresses, and ejaculations expressive of personal emotion and interest in the events narrated, as, for instance, the lengthy address to Cornwall as Domus Arturi. ${ }^{32}$ In fact, the poem begins with an address to the Saxons as Eurus and a prophecy against them in the second person. In the poem, also, the number of years is given for the

${ }^{30}$ See the article on John of Cornwall, Dictionary of National Biography, 1892, vol. 29, p. 435 .

${ }^{31}$ There are six of these questions coming at unequal intervals. (a) Line Io. Instaurans nostros princeps quot vixerit annos?, asked to determine the length of William the First's reign. (b) Line 52. Tune vides pecoris raptus per plana Reontis? Sed quid ages contra? (c) Line 64. Quae sua conditio? quae spes in semine nostro? (d) Line 91. Et quid tam sero fatali pendere castro? (e) Line 108. Haec ferit, ipsa facit, cur Neustria segnius hausit? These questions aid, in one way or another, in carrying forward the narrative.

${ }^{33}$ Beginning with line $5 \mathrm{r}$. 
reign of each of the first four kings, but Stephen is allowed two years too many. After Stephen the years are not given for any reign. ${ }^{33}$ The prophet in The Seven Kings continually identifies himself with the Welsh, and frequently uses such adjectives as "our" and such expressions as "our people" in referring to the Welsh. There is nothing of all this in The Book of Merlin.

There is a further difference, also, in the wording and arrangement of the material. As a rule, the sense of the two versions is the same, but the phraseology is different. The sinking of the White Ship is a good instance. Geoffrey's Latin for this episode reads,

\section{Catuli leonis in aequoreos pisces transformabuntur. ${ }^{34}$}

John renders this same episode in this fashion,

et Catulos Albania luget ademptos.

Heu! pelagi facinus quod tertius extulit annus. ${ }^{35}$

Similar differences are to be found throughout the two translations. John of Cornwall's rendering frequently seems to be the clearer; as for example in the 'Eagle of the Broken Covenant' passage. In the Book of Merlin this reads: "This (a bridlebit, not mentioned by John) shall the Eagle of the Broken Covenant gild over and the Eagle shall rejoice in her third nesting." According to The Seven Kings the passage should read, "The Broken Covenant (lex) will call the Eagle with the Cub into anger." The Eagle's third nesting is not mentioned until fifteen lines later. Other divergences in favor of greater clearness are to be found in John's version. It is useless to go further into these details in this place. It is sufficient to point out some typical differences characteristic of all.

Details which remain the same in the two versions are fre-

${ }^{33}$ This would indicate that the original was put together early in Stephen's reign, and that the reference to Henry's accession was a later addition made without changing the number of the years allotted to Stephen.

${ }^{34}$ Giles, I 22.

${ }^{35}$ Lines $31-32$. 
quently shifted in their order; as for example the events recounted as occurring during the reign of the Lion of Justice (Henry the First). According to Geoffrey the account runs: $:^{36}$

"The Lion of Justice shall succeed at whose roaring the towers and dragons of the island shall tremble. In those days gold shall be wrung forth from the lily and the nettle, and silver shall flow from the hooves of them that low. They that go crisped and curled shall be clad in fleeces of many colors, and the garment without shall betoken that which is within. The feet of them that bark shall be cropped short. The wild deer shall have peace, but humanity shall suffer dole. The shape of commerce shall be cloven in twain: the half shall be round. The ravening of kites shall perish and the teeth of wolves shall be blunted. The Lion's whelps shall be transformed into fishes of the sea, and his Eagle shall build her nest upon mount Aravius. Venedotia shall be red with mother's blood and six brethren shall the house of Corineus slay. The island shall be filled with nightly tears. ...."

\section{This is rendered by John of Cornwall thus : ${ }^{37}$}

"But the Lion of Justice restrains the talons of kites and the teeth of wolves, and makes woodlands and harbors safe everywhere. Whenever he roars, the towers which the Sequana washes, and each island of dragons tremble even under the ocean. Then he who is crisped shall put on cloaks of various colors, and the garment shall not protect the misdeed of a changeable mind. Then gold shall be wrung from the narcissus and the thorn, and shail flow from the horns of the flocks. Therefore, willingly or not, the barker makes peace with the deer on penalty of a lopped foot. The image of the nummus is cut: then also succeeds the shape of the round half. Then the renowned bird (elsewhere the Eagle) makes her nest upon Aravius and Albany grieves for the lost cubs. Alas the villainy of the sea which the third year brought forth! He was famous whom it moves not with its threefold wildness. In the six Frenchmen, the blood of one mother, the Throne (of Arthur, Cornwall), sadly red, bewails so many deaths, so many misfortunes and says, 'Normandy, do you know what is being done? Lately I grieved, lately I poured out my vitals. With these miseries you solaced our misfortunes. Island, you are drenched in tears.' ",

The Seven Kings contains within the same limits more material than The Book of Merlin. The two versions are practically the same to the end of the passages quoted. Then in The Book of Merlin come the episodes of the 'newcomers,' 'he who possesses through impiety,' 'the awakening of Albany to

${ }^{36}$ Evans, I75; Giles, I2I f.

${ }^{37}$ Line $I 7 \mathrm{f}$. 
wrath,' 'the forging of the bridlebit,' and 'the Eagle of the Broken Covenant,' all of which is covered in The Seven Kings in three lines. In both versions the war against the Bulls follows. After this episode John of Cornwall introduced thirteen lines referring to Welsh affairs that are not mentioned by Geoffrey. This interpolation is followed by the episode of 'the helmeted one' which had preceded the 'Broken Covenant' in The Book of Merlin. Then comes the confusion of the numbers which Geoffrey put immediately after the war against the Bulls. Another interpolation of sixteen lines intervenes before the episode of Sextus which had followed the numbers in The Book of Merlin. The achievements of Sextus agree in both, but The Seven Kings contains the fuller account of them. In both Sextus is succeeded by the Lynx and the downfall of the Normans. John barely mentions the Lynx, but describes at more length the expulsion of the foreigners.

John of Cornwall was not versifying Geoffrey's book. There is no instance of his taking a phrase from The Book of Merlin. His interpretations and renderings of many passages differ very much from Geoffrey's. This could be accounted for only by the supposition of forgery on his part. But his standing in his own time and his reputation for a knowledge of Welsh forbid the imputation. It is assumed on the strength of his own statement that he had a Welsh original. It is certain that his poem contains more references to contemporary Welsh prophecies than The Book of Merlin. The Cadwallader-Conan episode is common. The mention of events occurring at the Theivi and at Reon in connection with the coming of Cadwallader and Conan ${ }^{38}$ brings the poem into relation with the Afallenau, the Hoianau, and the Kyvoesi Myrdin, all Welsh predictive poems of the same century. ${ }^{39}$ The three hundred and sixty-three years, spoken of at the end of the poem as the golden age of Welsh liberty, seem to correspond to the three hundred and three years assigned Cadwallader in the Kyvoesi Myrdin. None of these poems, however, is the original of

${ }^{38}$ Lines I I 8-I 20.

${ }^{39}$ See these poems in W. F. Skene, The Four Ancient Books of Wales, Edinburgh, 1868 . 
this version. But the evidence got from all indicates the existence of some common material which was used freely in various poems with other material peculiar to each poem.

There are indications of yet another twelfth century collection of prophecies, if Giraldus Cambrensis is to be trusted. Giraldus was greatly interested in political prophecies and quoted them at every opportunity. He even proposed making the third book of the Expugnatio Hibernica a collection of them. He says in his preface to this book that prophecies attributed to Merlin Silvester, or Caledonicus, were sung by Welsh bards; but that he had difficulty in obtaining them, because they were rarely committed to writing. However he found a copy of them at Nevin on the West coast of Carnarvonshire during the itinerary through Wales with Archbishop Baldwin in II88. Henry the Second seems to have shared his interest and to have encouraged him in his work. The collection found at Nevin was greatly corrupted by interpolations, additions, and adaptations made by the bards. Giraldus called Welsh scholars to his aid and sought to free the text from corruptions, but he was not entirely successful, if he does interpret one fragment correctly as applying to Becket. This may, however, be an old prophecy that had been revived and warped to the desired interpretation. Martyrs lived and died in the British Isles before Thomas à Becket defied his King.

A collection of prophecies under the name of Merlin Silvester, or Caledonicus, and sometimes called The Prophecy of the Eagle, is found in several manuscripts of the thirteenth century. ${ }^{40}$ Three of the episodes contained in it are quoted by Giraldus and referred to Merlin Silvester. ${ }^{41}$ Two more are quoted on the authority of Melingus Hibernicus. Ward suggested that this collection was compounded of sentences from the Expugnatio, but granted that the case may have been the reverse. The latter seems more likely, since the two collections, which appear in the manuscript as one, both refer to events

${ }^{40}$ Printed in A. Schultz's edition of the Historia, 1854, p. 463 , as a note to chapter 18 of book 12 .

${ }^{41}$ See the discussion in Warde, loc. cit., vol. I, p. 293 f. Giraldus after quoting these fragments says that they are to appear in the vaticinal book. 
of the twelfth century and were most probably put together before I200. Furthermore, the collection contains three lines of the Here Prophecy, ${ }^{42}$ which can be dated approximately I I90. There is no proof that it is the collection made by Giraldus, but hereafter, since old names were frequently applied to new material after 1200 , it will be called the Giraldian Collection for the sake of clearness.

The first part of this Giraldian Collection is short and little more than a succession of vatic symbols. The invasion of Ireland and Henry the Second's quarrels with his children are 42

Zan zu seches in here hert yreret,

Zan sulen Hengles in pre be ydeled

Zat han sale into Hyrlande alto lade waya;

Zat hozer in to Poile mid pride bileve;

Ze thirde in harye haughen hert all ... ydreghen.

(Benedict of Peterborough, Chronicle of the Reigns of Henry II and Richard I, ed. Wm. Stubbs, Rolls Series, 2 vols., London, I 867 , vol. 2, p. I 39.) This prophecy was said to have been found written on tablets of stone and erected on a house at Here given Ralph Fitz Stephen by Henry the Second. Roger of Hoveden (translation by H. T. Riley, 2 vols., London, I853, vol. 2, p. I70) quotes the same prophecy and reads wreke for the lacuna in the last line.

The last three lines are identical with the last three clauses of an episode in the Giraldian Collection, which runs thus:

"In ultimis diebus albi drachonis semen jus trifarium spergetur, pars in Apuliam tendens orientali gaza locupletabitur, pars in Yberniam descendens occidua temperie delectabitur, pars vero in patria permanens vilis et inanis reputabitur."

The identity of the two cannot be doubted.

The English version is written as verse, but it neither rhymes nor alliterates. It would seem therefore a line for line translation of verse in some other language. The three Latin clauses in the episode quoted seem metrical, and doubtless belonged to the original. If placed metrically they read,

\section{"Pars in Apuliam tendens orientali gaza locupletabitur Pars in Yberniam descendens occidua temperie delectabitur Pars in patria permanens vilis et inanis reputabitur."}

Even this arrangement presents some difficulties, for the lines do not agree in the position of the accents and are clearly not written in a quantitative meter. They seem, however, to contain a detritus of a former metrical form. A close study of the various manuscripts might reveal a more uniform version. 
almost the only historical details. Geoffrey's Lynx is mentioned in it. The Lion may also represent Geoffrey's Lion of Justice, for it seems to stand for Henry the First. The Boar is used for Henry the Second as in The Seven Kings. With these exceptions the prophecy is independent of the others. The other symbols are a sombre dragon, a ram with delicate fleece, a kinglet, a sea-crab, the whirlwind that overthrows Ireland, a Fifth whose chariot is rolled into the place of the Fourth, a fiery ball from Eurus, and a spark from this ball. Some of the prophecy can be interpreted in terms of actual history, but the possibility of such interpretation does not prove it written after the events it seems to narrate. The danger of such a conclusion has been pointed out in the study of The Book of Merlin. The conquest of Ireland is not described any more definitely than in the II35 announcement concerning Sextus. The prophecy is best considered genuine, so far as independence of actual history is concerned, with interpolations concerning Henry the Second's family dissensions.

The second part of The Giraldian Collection is also short. It covers the reign of Stephen and is chiefly concerned with the wars between him and the opposing faction of the empress Matilda and her son. The prophecy begins with the succession of the albus rex et nobilis in Brittania (Stephen) after the death of the Lion of Justice and ends with the accession of the Eagle's Chick (pullus Aquilae, Henry the Second). The Lion of Justice and the Eagle's Chick are perhaps echoes of The Book of Merlin in which the Lion of Justice was used for Henry the First and the Eagle in two places where it can be interpreted as the Empress. This prophecy seems to have been made after the events described had taken place. It is, therefore, important as showing how early the conventions of the form were used with original material without the necessity of translating from the Welsh. It also shows that symbols which had become traditional, such as the Conquest of Ireland and the use of the Eagle for Matilda, were used as common property by any one who wished to treat them so.

This chapter has shown that at some time between the years II20 and II35 Geoffrey of Monmouth produced The 
Book of Merlin and thereby introduced into England a new type of literature. In II56 another version of the same material was made by John of Cornwall. In II 88 Giraldus Cambrensis found on the West coast of Wales an altogether different collection of prophecies attributed to Merlin Silvester, or Caledonicus, who had become distinguished from Ambrosius Merlin of The Book of Merlin and of the Historia. The testimony of Giraldus shows that prophecies attributed to Merlin were common in Wales and that they were sung by the bards, who corrupted them greatly. Geoffrey, John, and Giraldus, all professed to translate from the original Welsh, and each spoke of the difficulty he encountered in his work. Geoffrey and John undertook to translate at the bidding of learned and cultivated bishops. Giraldus was encouraged by Henry the Second himself. Material so introduced could scarcely have failed to become popular. By the end of the thirteenth century political prophecies had struck deep root in England, and, as later chapters will show, the Galfridian type, which had originated in England, had spread to other countries.

The importance of Geoffrey of Monmouth in the history of the political prophecy in England cannot escape notice. Although he did not originate his material, yet the credit for making it accessible to England and to the Continent is due him. Furthermore, by The Prophecy of Ganieda he set the example for the creation of new prophecies from new material but written according to the conventions of the prophecy as found in The Book of Merlin. Attention must now be turned to the question of the origin of the type, which was postponed in this chapter. It will therefore be discussed in the next chapter. 


\section{CHAPTER TWO}

\section{The Source of The Book of Merlin}

The source of The Book of Merlin has never been determined. Two theories in regard to the matter are possible; either that Geoffrey forged the prophecies himself, or that he told the truth in saying that he translated them. Scholars and critics who doubted the veracity of Geoffrey's remarks about 'the lost British book' carried their skepticism so far as to disbelieve his oath in regard to the prophecies. Professor Brandl $^{1}$ does not allow the existence of any original, but says that Geoffrey forged them with The Book of Daniel and The Fifteen Signs before the Judgment as models. Since this opinion was first expressed, no one has controverted it. But a careful comparison of these with The Book of Merlin leads one to believe that Professor Brandl wrote from general impressions rather than from any accurate information gained by special investigation of the subject.

It has been shown that the peculiar feature of The Book of Merlin is the use of animal figures to represent living individuals. Whatever likeness there is between Geoffrey's work and The Book of Daniel consists in the use of symbols that seem to resemble each other. But the likeness ends here, for the figures used in the two prophecies are really dissimilar. Professor Brandl failed to discriminate between them before he delivered his opinion. In The Book of Daniel the animals are all monsters. They represent not individuals but nations, and are therefore abstractions. For instance, the ram and the hegoat in the eighth chapter represent the Persian Empire and the Empire of Alexander the Great respectively. The four horns that rise on the head of the goat in the place of the single horn stand for the four kingdoms founded on the ruins of Alexander's Empire. The little horn that sprouts from one of

\footnotetext{
${ }^{1}$ A. Brandl in Paul's Grundriss, Strassburg, I893, 2 ; 1 ; 621.
} 
them represents a king of one of the four. In The Book of Merlin the animals are not monsters, however much their behavior may differ from that of real animals. They are not abstract ideas personified, but, on the contrary, representations of actual individuals.

As for the legend of The Fifteen Signs before the Judgment, no resemblance between it and The Book of Merlin can be found. The only part of The Book of Merlin that contains anything but the characteristic animal-symbolism is the close, which has been quoted from. It is an astrological description of astronomical phenomena to occur at the end of the world, and can fulfill only one Sign, the disorders in the Heavens. The drought mentioned at the beginning of the passage and the resurrection of the dead at the close answer to two other signs, but they can scarcely be considered results of any influence, for they were commonplaces of medieval theology, and as they stand in The Book of Merlin are episodes too insignificant to count. The rising of the sea above the mountains, the sinking of the sea from sight, the return of the sea to its original level, the congregations of the sea-animals, the warring of the rocks together, the earthquake, the levelling of the hills, the madness of men, the return of the saints, the birth of children with gray hair, the coming of Anti-Christ, the dripping of blood from trees and shrubs, all of which occur in one or another form of the legend, ${ }^{2}$ are not mentioned, referred to, or even alluded to in any way in The Book of Merlin. Geoffrey did not forge The Book of Merlin with The Fifteen Signs before the Judgment as a model.

It may be argued that if Geoffrey did not use The Book of Daniel and The Fifteen Signs before the Judgment, he may have drawn from the large body of vaticinal literature that had

${ }^{2}$ The various forms of the legend are shown in the following discussions of it: (a) H. E. Sandison, Quindecim Signa ante Judicium, Herrig's Archiv, New Series, Vol. XXIV, p. 73 f., Brunswick, 1910. (b) G. Nolle, Die Legende von den fünfehn Zeichen vor dem jüngsten Gerichte, Beiträge zur Geschichte der Deutschen Sprache und Literatur, Vol. VI, Halle, I879, p. 4I 3 f. (c) G. Grau, Quellen und Verwandtschaften der älteren Germanischen Darstellung des jüngsten Gerichtes, Morsbach's Studien zur Englischen Philologie, XXXI, Halle, 1908. 
preceded him. This consists of the Biblical, the classical, and the early medieval prophecies. A careful investigation of it, however, reveals as little influence on The Book of Merlin as those just discussed.

The average reader would undoubtedly think first of the Biblical prophecies as those most likely to be imitated by one wishing to forge a prophecy. Professor Brandl thought first of The Book of Daniel because animal figures appear in it. Other books of the Bible which might occur to one for a similar reason, or because they use some kind of symbolism that impresses the mind of the reader for its obscurity, are Isaiah, Ezekiel, and the Apocalypse. In the books of Jeremiah, Hosea and the so-called Minor Prophets the vaticinal method is that of simple and direct statement, although the language is frequently figurative and ornate. This method is not wanting in the three first named. In The Book of Isaiah the symbolism consists chiefly of allegory and parable. A good instance is the description of God's wrath against the Israelites and his purpose in regard to them, as set forth in the parable of the vineyard that produced only wild grapes. ${ }^{3}$ Animal names occur in the allegory which tells of the peace that shall attend the advent of Christ, but they are used as metaphors; they can in no sense be considered as prophetic symbols. ${ }^{4}$ What is true of The Book of Isaiah is true of The Book of Ezekiel, but the latter contains allegorical visions also. However, the same dearth of animal figures used as prophetic symbols is noticeable. In one passage Pharaoh is called 'The Great Dragon,' but the name is only a metaphorical epithet."

In The Apocalypse of St. John the Divine the prophecy is in the form of a vision. Besides the material that is purely prophetic the book contains preaching against heresy and an exhortation to repentance. In the vision itself are many angels

\footnotetext{
${ }^{3}$ Isaiah, V; 5-6.

4 " The wolf also shall dwell with the lamb and the leopard shall lie down with the kid: and the calf and the young lion and the fatling together: and the lion shall eat straw like an ox." (Isaiah, XI; 6.)

5 "Behold I am against thee, Pharaoh, King of Egypt, the great dragon that lieth in the midst of his rivers which hath said, My river is mine own and I have made it for myself." (Ezekiel, XXIX; 3.)
} 
passing to and fro on various missions, a black sun, a red moon, falling stars, an earthquake, and monsters in abundance. These monsters include locusts that looked like horses prepared for battle, having hair of women, teeth of lions, and tails of scorpions each with a sting: a red dragon with seven heads and ten horns, each head crowned: a beast of the sea with seven heads and ten horns, each horn crowned: and a beast with two horns of a lamb speaking as a dragon. In the sixth chapter in connection with the opening of the seals, four horses are described naturally, but they are allegorical personifications respectively of Conquest, Riot, Justice, and Death. ${ }^{6}$

This discussion of Biblical prophecies should be sufficient to show wherein they differ from The Book of Merlin. Both use animal-symbolism, but in the former the animals, when used, are monstrous personifications of abstractions; in the latter they are life-like and represent individuals.

The vaticinal literature of Greece and Rome is of slight extent, perhaps because of the great attention each country gave to the various kinds of divination. It is composed largely of oracles given by different deities or by persons supposedly endowed with prophetic insight. Geoffrey of Monmouth could have known very little of it, and if he had known the whole body, he could have got very little help from it. In Rome this literature consisted of the famous Sibylline Books, the Carmina Marciana, the Oracles of Begoe, and the Books of Veii. Of the last two nothing is known but the name. The Sibylline Books, as far as can be judged from the few extant fragments, were chiefly admonitions to adopt certain rituals to expiate some evil or to avert some threatened calamity. The Carmina Marciana were only vague and indefinite warnings that contained no symbolism. The Greek Oracles of the classical period were usually very short and direct. They were frequently evasive,

${ }^{6}$ What has been said of the orthodox books of the Bible is also true of the apocryphal books. They contain nothing that could have helped Geoffrey. The Book of Esdras is typical. "But if the Most High grant thee to live, thou shalt see that which is after the third kingdom to be troubled: and the sun shall suddenly shine forth in the night and the moon in the day: and blood shall drop out of the wood." (Esdras II, v; 4.) Monsters similar to those in The Apocalypse are also found in this book. 
misleading, or deliberately enigmatic, but contained little symbolism. Such was the doubtful assurance given Croesus that if he crossed the Halys he would put an end to a great kingdom. Another typical oracle is that given the same Croesus bidding him flee when a mule should become king of the Persians, which was fulfilled in Cyrus the Great, the son of a Persian father by a Mede mother.?

One collection of Greek Oracles $^{8}$ deserves some detailed mention, not because of any influence it exerted on Geoffrey of Monmouth, but because it is the source of the kind of prophetic writing which was most popular in his day and which he would

'These prophecies or oracles are as a rule very short and do not attempt to foretell a long sequence of events in the future. Occasionally bits of symbolism are to be found, but they are usually to be explained as puns. A good example is that recorded by Herodotus relating to Cypselus, the tyrant of Corinth:

"An eagle will nest in rocks and bring forth a strong and brutal lion and he will knock the knees from many. Now be advised in these matters, ye Corinthians who dwell about the beautiful Peirene and towering Corinth." (Herodotus, V, 92.)

The pun is on the word aietos, meaning eagle, and Aetion the father of Cypselus. Lion is rather a metaphor than a prophetic symbol. A similar oracle, attributed to Phaennos, tells of the victory won by Attalus, King of Pergamus, over the Gauls in 270 B.C. In it Attalus is spoken of as descended from the illustrious race of the bull, but Tauros, bull, seems to have been the usual cognomen of the family.

Another oracle of Phaennos addressed to Lysimachus, King of Thrace, contains a bit of symbolism not so easily explained:

"O King of the Thracians, you will receive a city among flocks. You will raise to honor a great and dangerous lion who will at some time stir the fatherland to its foundations: he will take the land without trouble. And I say that you shall not be made glorious by the sceptral honors, but that you shall fall from the king's estate when dogs surround you. You will arouse a terrible sleeping wolf. He will not willingly put his neck beneath the yoke. Then the wolves of Bithynia will inhabit the land according to the foreordinance of Zeus. . . . So the law of the gods commands when a fierce wolf will undergo the hard yoke of fate."

The lion and the wolf of this prophecy have both been identified as Seleucus, King of Syria, but the interpretation is doubtful after the very beginning.

${ }^{8}$ For a detailed discussion of vaticination in Greece and Rome consult A. Bouché-Leclerc, Histoire de la Divination dans l'Antiquitè, Paris, 1882, 4 vols. 
probably have adopted had he been in search of a model. They are the so-called Oracula Sibyllina. As the collection stands to-day, it consists of a Proemium and twelve books numbering from one to eight and from eleven to fourteen inclusively. ${ }^{9}$ It was begun, apparently, by a nameless Alexandrian Jew in the second century B.C. during the wars of Antiochus Epiphanes against the Jews, and was continued at various times by various writers, Jewish and Christian, to a period shortly after the death of Odenathus in 268 A.D. ${ }^{10}$ The last books were evidently written by a Jew who still believed in the possible political resurgence of his people.

The earliest form of the Oracula Sibyllina was written to encourage the Jews in a time of danger from a political enemy, and promised them not only victory in the war but also the ultimate triumph of their religion. The writer shrewdly turned the weapons of his foes against themselves by writing in Greek, adopting the form of the Sibylline Oracles, and attributing his work to a Sibyl. The prophecies spoke of the Jews' hope in a coming Messiah. The early Christians, coming in contact with this material and considering the Messianic prophecy fulfilled, accepted the rest as genuine and ranked the Sibyl with the greatest of the Hebrew prophets. In the Dies Irae the Sibyl is coupled with David. Quotations from the first eight books are frequent in the writings of the Church Fathers for four hundred years, but after the fourth century the Greek scholars and theologians seem to have given the Oracula little credence. In the West, however, the belief in them lingered longer. St. Augustine in the sixth century quoted with admiration the famous acrostic of Christ in the eighth book. Sedulius, a Frankish monk of the ninth century, collected the fragments scattered in the writings of the Church Fathers. The type must have been familiar in the tenth century, for in that century Luitprand applied the adjective Sibyllini to certain prophecies he saw at Constantinople.

The Oracula Sibyllina is a disorderly mixture of hymns,

${ }^{9}$ The eighth book is long and contains what would be books nine and ten, if so divided.

${ }^{10}$ Oracula Sibyllina, ed. C. Alexandre, 2 vols., in 3 parts, Paris, 1841-69. 
ecstatic and mystical writing, historical narrative, and prophecy. For instance, the first and second books, written rather late, are really one poem of the Cursor Mundi kind, and like it narrate the history of the world from the Creation. Judaistic and Christian theological ideas are strangely confused throughout the whole-a confusion due to the heterogeneous origin of the various parts. The beginnings of many legends popular during the Middle Ages, such as the story of Anti-Christ, and The Fifteen Signs before the Judgment, are also to be found here. Political events are often told in the guise of prophecy, and pure prophecy occurs not infrequently. Various vaticinal methods were used. Direct prophecy abounds. At other times the disguise is so slight that it is really nothing more than a kind of poetic allusion or a bit of ornamental description. Such a case is the reference to the Romans, ${ }^{11}$ "There will be the rule of another kindgom, white and many-helmeted, from the western sea, which will rule much land and cause consternation to many."

Since this passage was written during the Roman supremacy, disguise was hardly necessary. A king is often referred to by his number in his dynasty. "Even until the seventh kingship over which will rule the King of Egypt who will be of the Greek race," refers simply to the seventh Ptolemy. In the earlier books prophecy connected with individuals is sometimes made by simple reference to a man and his deeds without naming him. In such fashion Vespasian, or Titus, is referred to as a champion of Rome who will come into Syria, set fire to a temple, slay many with the darts of war, and kill the Jews in their own city of the wide-streets.

The method of prophetic disguise peculiar to the Oracula Sibyllina begins early in the fifth book and is usual in the later books that deal very much with political affairs. It consists in referring to a man by the initial of his name expressed by that letter's numerical value in the Greek system of numerical notation. 'The first king will be one who sums up two tens with his initial' refers to Caesar, since Kappa, with which the Greek form of the name begins, represents the numerical value of

"Oracula Sibyllina, III, I75 f. 
twenty. In like fashion Claudius is later referred to as twenty, Tiberius as three hundred, and Caligula, whose real name was Gaius, as three. The list might be prolonged indefinitely. An exception to the general rule is made in the case of Augustus, who is called the first letter of the alphabet, and in the case of Hadrian, who appears as the man named for a sea, the Adriatic. This initial-reference so characteristic of the Oracula Sibyllina was popular late into the Middle Ages. But the numerical element was discarded in the West as soon as the Greek system became unfamiliar, for the Latin numerical system contained too few characters to meet all occasions. Therefore, instead of translating the initials into numerical equivalents, the initials themselves were retained. This method of initialreference has already been defined as the Sibyllic.

Two cases of astrological prediction occur in the collection. The first of these is a passage in which the Ethiopians and Indians are told not to be frightened when Taurus and Gemini are in ascendance, and Virgo and the Sun in conjunction. ${ }^{12}$ The second is an account of the end of the world, and resembles in a general way the close of The Book of Merlin. Its astrological nature is apparent at orre; otherwise the animal figures contained in it would be incomprehensible.

"I saw the threats of the sun burning among the stars

And the terrible wrath of the moon in lightning flashes.

The stars were in labor with battle and God turned to the conflict.

Great flames stood in the place of the sun.

Lucifer leaped upon the back of the Lion and gave battle.

The two-horned moon changed her phase;

Capricorn smote the foot of the young Bull

And the Bull deprived Capricorn of the day of return.

Orion no longer allowed Libra to remain stationary.

Virgo changed places with Gemini in Aries.

The Pleiades shone no longer and the Dragon declined the girdle.

Pisces slipped into the baldric of the Lion

And Cancer did not remain, for he feared Orion;

The Scorpion traversed the tail of the Lion

And the Dog fled from the heat of the sun.

Aquarius lighted the strength of the greater star.

Heaven itself was aroused so that it disturbed the combatants

${ }^{12}$ Oracula Sibyllina, V, 206 f. 
And threw the stars headlong to the earth;

These falling swiftly into the Ocean's bath

Burned the whole world, and heaven itself was devoid of stars. ${ }^{13}$

Genuine animal-symbolism occurs at two places in the last two books of the Oracula Sibyllina. These two passages are the only ones that bear any resemblance to The Book of Merlin except its close, and they occur in books that seem to have been little known before the nineteenth century. ${ }^{14}$ The longer passage is really quite short; the animal names in the other are metaphorical rather than symbolical. The first is the longer and runs:

"Then will rule the insolent Romans two princes, men swift in war; one will have the number seventy (Valerian): the other will be the third number (Galienus) and then the haughty bull digging the earth with his hoofs and stirring the sand with his horn will inflict many evils on the dark crawling serpent (Sapor, King of Persia) dragging away his tail with his scales, and then he will die. Then will come after him another well-horned stag (Macrianus) thirsting on the mountains, longing to have in his stomach the arrow-shooting quarry. Then a dreadful Sun-sent Lion (Odenathus) will come breathing fire, and will destroy the well-horned and active stag and the great arrow-shooting quarry, the archer, the hegoat, which sends out many whistling sounds. The Lion will rule Rome. . . ."15

The second example is a reminiscence of this, and is more a matter of metaphor, as has been said. It runs :

"But there the Lion, vanquisher of Bulls, bold with strength, with a fearful mane, will scatter the whole flock and the keepers, and no strength will be left them, unless young dogs swift of foot follow the Lion through the wooded valleys. And a Dog followed him, killing the flock. Then will rise a four-syllabled king, bold in strength, signified by the unit, whom the iron hand of Mars and the wild rage of a jealous enemy will soon slay."16

${ }^{13}$ Oracula Sibyllina, V, 510. The translation here is line for line of the original.

${ }^{14}$ Only the first eight books were printed before 1817 when Cardinal Maio printed book XIV. How much was known of the last four books before that time is uncertain. The earliest reference to them found in this study was by J. Wolf, Lectionum Memorabilium Centuriae, Lavingae, I66o?, 2 vols., I, p. 73. Here he speaks of a Vatican ms. containing all fourteen books. It is not impossible that these passages are late interpolations.

${ }^{15}$ Oracula Sibyllina, XIII, I55-I69.

${ }^{18}$ Oracula Sibyllina, XIV, $12 \mathrm{f}$. 
Following this passage the Sibyl continued in the usual method, and named a long list of emperors who never reigned. Passing references are made to a wolf, a lion and lioness, and a mighty ram.

One of the most common themes in the Oracula Sibyllina is the Fall-of-Rome motive, which was dear to both Christians and Jews, but for different reasons. To the Jew it meant the possible revival of his national existence, and therefore it was eagerly prophesied. But the Christian had never known a national existence, and, having no national traditions, he naturally regarded Rome as the incarnation of governmental authority. To him the dissolution of the great Roman Empire meant the end of the world and the fulfillment of his hopes for the coming of his ideal Prince and the founding of the spiritual kingdom. Consequently, on every promising occasion the Christians prophesied the fall of the empire and the immediate end of all things temporal. ${ }^{17}$ Around what was at first a simple statement of the impending catastrophe grew up a mass of theological doctrine that was long popular and was later developed into The Fifteen Signs before the Judgment. These signs as enumerated in the Oracula are the Fall of Rome, disorders in the heavens, the birth of children with gray hair, the return of the ten tribes, the return of Elias, the reign of a woman, and the coming of Anti-Christ.

The origin of the legend of Anti-Christ is uncertain. Its first appearance in Christian literature seems to be in Paul's Epistle to the Thessalonians. ${ }^{18}$ It was later combined with the story of Nero's escape to Parthia, whence he was expected to return and regain possession of Rome. Nero made an excellent Anti-Christ. The identification with him was in time forgotten, but his storied abode in Parthia gave AntiChrist a permanent place of origin in the East. The adoption of Christianity as a state religion modified the legend, for the Empire now became the champion of Christianity, and the success of Anti-Christ meant the defeat of a Christian prince

\footnotetext{
${ }^{17}$ Prophesied on the extinction of the Caesarian house; at the time of the Fall of Jerusalem; and on other similar occasions.

${ }^{18}$ Thessalonians, II, 2-3.
} 
and the overthrow of a Christian government. To avoid this a new legend arose that the last king of Rome would not be conquered by Anti-Christ, but that at the birth of the Prince of Evil he would go to Jerusalem and renounce his power at the foot of the Cross. This is the so-called Last King of Rome prophecy.

The prophecy concerning the Last King of Rome is first found in the Eastern Empire ${ }^{19}$ in the writings of the PseudoMethodius $^{20}$ and in the apocryphal apocalypses of Daniel. ${ }^{21}$ In the Book of Methodius the prophecy is very simple. In the seventh millenary the Ishmaelites rise and sweep victoriously over a large part of the world. "Then suddenly a King of the Greeks or Romans will leap upon them, and he will be aroused as a man from drunkenness whom men had considered as dead and useful in no way." This king and his sons conquer the Ishmaelites and rule in peace until the nations whom Alexander had shut behind the Black Sea break their bonds and invade the Empire. The King overcomes them, and retires to Jerusalem where he lives until Anti-Christ appears. He then climbs Golgotha, hangs his crown upon the Cross, surrenders his kingdom to God, and dies. Anti-Christ then rules for a time, but is slain by God himself before the Judgment. This prophecy reappears in the apocalypses, but the

${ }^{19}$ Kampers, Kaiserprophetieen and Kaisersagen in Mittelalter, Historische Abhandlungen, VII, Munich, 1895, p. 214, endeavors to establish a similar secular prophecy among the Romans. He argues from the Apollo-prophecy in Vergil's Fourth Eclogue, the Daphne-Constantinia coins of Constantine's reign, the phoenix-engravings on the tombs of the Roman Emperors, and the prophecy made to the Emperor Tacitus that a descendant of his would subdue the world and return his power to the Senate after living 120 years. This last prophecy is the only important detail, but Kampers fails to show that it had any but an ephemeral existence, or gained any permanent credence.

${ }^{20} \mathrm{E}$. Sackur, Sibyllinische Texte und Forschungen, Halle, I898, p. 55. The Book of Methodius exists only in a Latin translation from the Greek. The oldest ms. was written in France and dates from the eighth century. Internal evidence shows that the Book belongs to the seventh century.

21 (a) P. G. Kalemkiar, Der Siebente Vision Daniels, Wiener Zeitschrift für Kunde Morgenlands, Wien, 1892, VI, 109-36, 227-40. (b) A. Vassiliev, Anecdota Graeca-Byzantina, 2 vols., Moskow, 1893, vol. I, p. 33 f. 
traditional material has undergone some modifications and new material has been introduced. Occasional bits of animalsymbolism are found such as the one quoted by Luitprand, "The Lion and his son will pursue the onager," but they occur only in fragments. No sustained or consistent animal-allegory is attempted. ${ }^{22}$

The Last King of Rome was known in France as early as the eighth century, as the manuscrpit of Methodius shows. In the next century Adso ${ }^{23}$ in his letter to Queen Gerberga on Anti-Christ retold the prophecy with a purely local variation to the effect that the Last King would belong to the Frankish dynasty. The reason for this variation is to be found in the political history of the time. The imperial crown of Charlemagne had passed from the Franks to the Germans, but the Franks never forgot their hereditary claim and were constantly looking for an opportunity to regain their lost honors. This prophecy crops up later in England, being applied to Edward the Third in accordance with his claim to the French crown.

The Sibylline tradition lingered long after the Oracula Sibyllina had lost its hold, and bore fruit in a long prophecy ascribed to the Sibyl Tiburtina. It was perhaps a continuance of the unorthodox Sibylline material of the Roman Empire, which left such scanty traces. ${ }^{24}$ Procopius offers incontrovertible evidence that similar material existed at Rome after the fall of the city. ${ }^{25} \mathrm{He}$ mentions one that is especially note-

${ }^{22}$ Byzantine prophecy was not confined to these visions of Daniel. Other prophecies were attributed to Stephen of Byzantium. In the eleventh century some Oracles were atributed to Leo the Philosopher who has been confused with the Emperor of the same name. They consist of a series of sixteen pictures representing the future, each with a metrical interpretation which occasionally contains bits of animal-symbolism.

${ }^{23}$ Sackur, Sibyl. Texte, has shown that the C.-Passage relating supposedly to an emperor with that initial is an interpolation.. Kampers and others who have looked for a seventh century Byzantine prophecy of a Constans are advised to study Vassiliev, loc. cit., I, 39, where they will find a prophecy of a king whose name will be the thirtieth letter, Lambda. Here is certain ground with no necessity for guess-work.

${ }^{24}$ This material has all been collected by Alexandre, Oracula Sibyllina, vol. 3 , p. Io7 f. and can be studied there to advantage.

${ }^{25}$ Procopius, Gothic Wars, I, c. 19. 
worthy in this connection ${ }^{26}$ as current in Carthage. It is to the effect that Gamma would expel Beta and Beta again expel Gamma. This is the Sibyllic method after its simplification. A century later the Sibyl is heard of in France. Fredegar's chronicle contains two entries ${ }^{27}$ relating to the Sibyls, both of which passages are found in the oldest manuscript. The first is a mere mention of Sevilla (Sibylla) and Europhile (Herophile, one of the classic Sibyls) as having repute in Samos. The second is a purely local prophecy on the Austrasian queen, Brunehilde, and is atrributed to Sevilla. It runs, "A Bruna coming from Spain before whose sight many nations will perish." Sedulius put in his collection of the Oracula Sibyllina some that are Arian in tendency and are not found in the orthodox collection, and must have another source. In the tenth century Luitprand ${ }^{28}$ describes the Greek apocalypses of Daniel as Sibyllini and must therefore have been familiar with some Sibylline material. A prophecy relating to Gerbert of Rheims, who became Pope Sylvester the Second, makes use of the Sibyllic method of initial-reference. It reads, "Transit ab $R$. Gerbertus ad $R$. post papa vigens R."'29

The Prophecy of Sibyl Tiburtina exists in several versions of different dates, one of which is attributed to Bede, ${ }^{30}$ but it seems not to be older than the eleventh century. All versions differ somewhat in references to affairs in Western Europe. ${ }^{31}$

${ }^{26}$ Procopius, Vandal Wars, I, c. 18.

${ }^{27}$ Fredegar, Chronicle, II, c. I9; III, c. 50.

${ }^{28}$ Luitprand, Legatio, c. 40.

${ }^{29}$ Ordericus Vitalis, Historia Ecclesiastica, book I, c. 24. " Gerbert goes from $R$ (Ravenna, his birthplace) to R (Rheims, where he became bishop), afterwards living as Pope in R. (Rome)."

${ }^{30}$ For different versions see: P. Ewald, Neues Archiv, 6, p. 249 f.; G. Waitz, Neues Archiv, 8, p. 172-175; F. Gerss,. Forschungen zur Deutschen Geschichte, 19, p. 373 ; R. Usinger, Forschungen z. D. Gesch., 10, p. 621 f.; Godfrey of Viterbo, Pantheon, book Io; Migne, Patrologiae Latinae, 90, col. I 8 I f. for version attributed to Bede.

a Frequent allusions are made to affairs in the East, and are obviously out of place in a prophecy dealing with German kings and Lombard princes. Some Byzantine original may be at the bottom of the trouble. Byzantine material may have entered Europe through Italy and have been combined with the Sibyllic tradition of the West. Benso of Alba, Panegyricus, I, c. 15, applies a Byzantine prophecy to Henry the Fourth of Germany. 
The method of the prophecy, aside from the narrative portions, is Sibyllic initial-reference. No animal figures of any kind are introduced, a fact which is very important, for this was the most popular and widespread prophecy at the time The Book of Merlin was produced. The traditional material relating to the Last King, the renunciation in Jerusalem, AntiChrist, and the uprising of Gog and Magog is given a very prominent place in the prophecy.

Three short prophecies are to be found which contain animal symbolism: The Vision of Childerich; The Anchorite's Vision; and The Vision of the Five Beasts.

The Vision of Childerich dates from the early eighth century. ${ }^{32}$ According to the story, Basina, wife of Childerich the Merovingian, on her wedding night sent her lord out thrice into the night to see what he could see. The first time he saw a lion, the second a bear and a unicorn, the third time wolves, dogs, and other small animals. This vision was supposed to portray the history of the Merovingian dynasty. The lion is easily identified as Clovis, the bear and unicorn as Dagobert and his son, the 'small deer' as the 'Do-Nothing' kings of later generations. The prophecy is remarkable as antedating the extinction of the dynasty.

The Anchorite's Vision ${ }^{33}$ is a prophecy of the twelfth century relating to the affairs of Normandy. It is a vision of a fair meadow full of flowers and protected by a wild horse from the cattle that stand on the borders. The horse dies, and a lascivious heifer of the flock undertakes the governance of the meadow, but the cattle destroy it. The meadow is interpreted as Normandy, the flowers the churches, the wild horse William the Bastard, the cattle the enemies of Normandy, and the heifer as Robert Curthose.

The Vision of the Five Beasts ${ }^{34}$ belongs to the same century.

${ }^{32}$ Fredegar, Chronicle, III, c. I2. This prophecy is found in the oldest manuscript which was written in 7 15 , as B. Brusch has shown in the introduction of his edition of Fredegar for Monumenta Germaniae, 1888. (Introd., p. 9 f.)

${ }^{33}$ Ordericus Vitalis, Historia Ecclesiastica, book V, c. Io. This chapter was written, as internal evidence shows, in 1126.

${ }^{34}$ Neues Archiv, 37, p. 600, printed from Codex Vaticana 1348 , twelfth century. 
Five beasts, a flame-colored dog, a tawny wolf, a white horse, a black hog, and a gray wolf, representing five kings who come from the North, are tied by ropes to a small hill in the west whence comes a voice. Anti-Christ appears with the last.

This closes the survey of vaticinal literature before II35. The survey has shown nothing that resembles the Merlin prophecies except fragments which it is not certain Geoffrey knew, three short prophecies two of which belong to the same century, and The Omen of the Dragons described in the preceding chapter. Otherwise the material and the vaticinal method of The Book of Merlin were new. Furthermore, the survey has shown that the Sibyllic method was universally employed in such writing during the Middle Ages. It has also shown what traditional material, such as the Anti-Christ and Last-King-of-Rome themes, was popular and was constantly used. The Book of Merlin contains no reference to this material and no suggestion of it. This omission must have been deliberate on the part of the writer, for Geoffrey certainly knew all these theological legends. The story of Anti-Christ had been popular throughout Christendom from the earliest centuries. The Last-King-of-Rome story with the attendant Renunciation-in-Jerusalem, had been familiar to the French since the ninth century, and must have been known in England at an early date. Geoffrey certainly knew of the Sibyl as a prophet, for he refers to her twice in the Historia as such. In one place ${ }^{35}$ he says that Alan consulted her prophecies with those of Merlin and the Eagle in regard to Cadwallader. In another place $^{36}$ he makes Hoel in a speech refer to a prophecy of the Sibyl that Britain should give another Emperor to Rome. ${ }^{37}$ The Prophecy of Sibyl Tiburtina was the most important long prophecy nearest his own day, and because of its popularity is the one he would probably have imitated..$^{38}$ It is certain that he did not imitate it.

${ }^{33}$ Evans, 324 ; Giles, 227.

${ }^{36}$ Evans, 256; Giles, 177 . In this last passage Geoffrey used the Latin word vaticinia, but in the former passage the word carmen.

${ }^{37}$ This may be an echo of the Last King of Rome.

${ }^{88} \mathrm{~A}$ twelfth century version is found to-day in the British Museum (Ward, loc. cit., I, r92-3.) 
The only resemblances to The Book of Merlin in the older prophecies occur in occasional passages, or are in very short and unimportant individual pieces. It might be argued that Geoffrey got from these few cases some suggestions which he developed and elaborated. Such a point would be hard to prove. Before adopting such a view it would be only just to examine the evidence in favor of Geoffrey's own statement.

The evidence against Geoffrey of Monmouth's word has been spoken of. In reality it is no evidence at all, but only distrust. The failure of scholars to find Archdeacon Walter's British Book ${ }^{39}$ prejudiced critics and scholars against Geoffrey. They have refused to take his word unsupported by other evidence, and have quoted with delight William of Newburgh's attack on Geoffrey's veracity as proving their point. So far as William of Newburgh's remarks prove anything, they prove that Geoffrey had originals of some kind for the Arthurian stories. William's real charge is not that Geoffrey lied, but that he had been unscholarly in accepting tradition as fact. ${ }^{40}$ William acknowledges that Geoffrey translated the prophecies from the Welsh. He says further, however, that

${ }^{39}$ There is nothing to show that The Book of Merlin was a part of the 'British Book.' There is really no indication as to the form of the original. Geoffrey says that he translated from the 'British' (de Britannico in Latinum, Giles, IIg). This might indicate that his original came either from Wales or from Brittany. In the prophecy the new dynasty that succeeds the Norman is clearly Breton. This episode may be referred to a Breton source. But if the rest of the prophecy is Breton it has been localized in England, for the places named in it are all in the British Isles. A more reasonable explanation is that the material came from Wales, and that Geoffrey may have known it from his boyhood. Scraps from several sources may have got into the collection.

${ }^{40}$ See translation of Newburgh's Chronicle by Jos. Stevenson, in The Church Historians of England, vol. 4, part 2, London, 1856, p. $398 \mathrm{f}$. It is really a serious mistake for any writer to quote only a passage from William's remarks in this connection, for a wrong impression is created. William's chief anger is directed against the Welsh, whom he evidently did not love, for devising the fable of Arthur and a past glory. The stock passage always quoted in reference to Geoffrey is misleading, unless it is studied in its context. William is really finding fault with Geoffrey for perpetuating what he considers lies and what he thinks Geoffrey should know were lies. 
many people believed that Geoffrey edited them to fit the truth and added guess-work of his own.

Although the "British Book" has not been found, scholars no longer insist that Geoffrey forged his material. The presence of Arthurian names in Italy in the early twelfth century proves the existence of Arthurian material independent of Geoffrey's book. ${ }^{41}$ Even the name that most concerns this study, Merlin, occurs in Italy in $1128,,^{42}$ early enough to disprove the statement that Geoffrey was the first to use it. ${ }^{43}$ The prominence of Merlin in the Uther-Igerne story as told by Godfrey of Viterbo ${ }^{44}$ shows that Geoffrey was not the

${ }^{41}$ V. P. Rajna, Gli Eroi Brettoni nell' Onomastica Italiana del secolo XII, Romania, 1888.

${ }^{42}$ I. Sanesi, Storia di Merlino, Bergamo, 1898 , xii. In May Ir 28 Galdia, wife of Merlin deceased, endowed the monastery of S. Salvatore, Taone. Her husband must have been born at least about the year $\mathrm{x}$ roo.

${ }^{43} \mathrm{~W}$. Lewis Jones, The Arthurian Legend, Cambridge History of English Literature, I, p. 298.

${ }^{44}$ Godfrey of Viterbo, Pantheon, Monumenta Germaniae, XXII. Godfrey heads the eighteenth chapter of the Pantheon, De Anglis et Saxonibus. He takes up the story of Britain with the accession of Constans the Monk, and concludes with the marriage of Uther and Igerne, saying that their son will be Arthur. He differs from Geoffrey of Monmouth in the names of the characters and in the details of the action.

Godfrey does not use the same spelling as Geoffrey, and sometimes changes the name altogether. Vortigern he calls Voltigern; Vortimer, Volgimer; Horsus, Orsus but apparently Orso, Orsonis, in oblique cases; Hengist loses the initial H.; Merlinus is sometimes shortened to Merlus for metrical reasons; Igerne becomes Hierna; the Picts appear as Quirites. The name Rowena does not occur, but in its stead he uses Angria, taken, he says, from the name of the country which was so called before Pope Gregory substituted an $L$ for an $R$. Angria is perhaps a pun on Deira, one of the divisions of the old Northumbrian kingdom. Dux Cornubiae represents Gorlois, who is not named; Ulfin of Ricaradoc, the friend who advised the king to consult Merlin and who went with him to Tintagel, gives place to an unnamed Medicum Gothorum, whom Uther consulted while the fever of love was on him. No name is given Igerne's castle of Tintagel.

Godfrey changes very much the genealogy of the Pendragon dynasty. He makes Uther and Aurelius the sons of Diocletian's colleague Maximianus, who, he says, had been sent to govern Britain. This is a two-fold mistake. The Maximianus sent to Britain was quite another man and in no way connected with the Pendragons, who were the sons of Constantine 
first to connect Merlin with the Arthurian material. This has not, I believe, been pointed out before.

The problem of the 'British Book' has been touched on here only as it concerns Geoffrey's reputation for veracity. It is

of Brittany. Constans the Monk he makes the uncle instead of the elder brother of Uther and Aurelius.

In the Pantheon the Saxons under the leadership of Orsus and Engistus are called into the country by Vortigern at the advice of an unnamed Saxon, and one of them slays Constans. The Britons, not liking the growing supremacy of the Saxons, elect Volgimer king. He defeats the Saxons, but the war is interrupted by Voltigern's attempts to make peace. The war is continued, and results in the defeat and flight of the Germans. They return after a time, and renew the struggle. Volgimer is defeated, and flees to the forest where he is said to have died of poison. Voltigern marries Angria, the sister of Engist and Orsus, and makes peace. In the Historia the Picts are introduced into the kingdom by Vortigern, and a Pict slays Constans. The coming of the Saxons follows Vortigern's accession. The marriage with Rowena takes place shortly after the landing of the Saxons. In the British outbreak Vortimer is successful and rules supreme until he is poisoned by Rowena.

Godfrey introduces the building of Vortigern's tower with no introductory explanations. Apparently it is built at the king's caprice, for no mention is made of the treachery of the Germans or to the massacre of the Britons. The account of the instability of the works agrees with that in the Historia, but the Latin phrasing is never the same. The search for the 'boy born without a father' and the finding of Merlin is told in the same way in both books. But in the Pantheon Merlin does not confront the Mages, who are put to death. They escape in the Historia. Merlin's explanation of the causes for the falling of the tower is given in greater detail, but agrees in the main with Geoffrey's account. There is, however, no hint of anything under the pool, and the appearance of the dragons is something of a surprise. No reference is made to the rock and the tent which conceal the dragons in the Historia. The dragons do not fight each other, but devastate the country until one is killed by Uther who gets thereby the surname Pendragon. The King and Queen in alarm ask Merlin to explain the portent of the dragons. He says that they represent Uther and Aurelius who are finally to get possession of the country. No such explanation is given in the Historia.

Immediately after the episode of the dragons and Merlin's interpretation follows a brief account of the war between Voltigern and the sons of Constantine, in which Voltigern is killed. Angria, aided by Orsus and Engistus, continues the hostilities, but finally agrees to a peace, and is granted the government of the Marine Fields. Aurelius becomes king, and although a Manichean in religion, proves to be a good ruler. He is succeeded by 
constantly suggested by the question of the sources of The Book of Merlin, but the two issues must be kept separate. Except as here indicated, the 'British Book' does not concern The Book of Merlin in any way. Its existence is important only as establishing the possibility that Geoffrey could and would tell the truth. It makes Geoffrey's own statement more credible. The evidence in support of his statement deals with quite other matters. This evidence is drawn both from external and internal sources, and leads unmistakably to the conclusion that The Book of Merlin was translated from a Welsh source of some kind.

It has been shown already that William of Newburgh, who is so frequently quoted against Geoffrey, says clearly that

Uther. In the Historia there is no mention of Rowena after the poisoning of Vortimer. Horsus furthermore was slain in the war against Vortimer. Aurelius was not a heretic, but a devout and orthodox Christian who cared for the rebuilding of the churches destroyed by the Saxons.

Godfrey omits many events in the reign of Uther. The first event recounted is Uther's meeting with Hierna, wife of the Duke of Cornwall, at the Easter festival. The Duke arose frightened at the King's attentions, and Hierna fled. War ensued between the King and the Duke. Uther fell sick with love of Hierna, and consulted a Gothic doctor, who failed to find the cause of the distemper. Merlin was then called. He diagnosed the case properly, and proposed the magic disguise to effect the King's desires. According to the Historia, Uther was not sick, but consulted Ricaradoc concerning means of gaining his end, and Ricaradoc recommended that Merlin be called.

Merlin and Uther went alone to Hierna's castle which was some distance from that in which the Duke was staying. The Duchess welcomed the King in the semblance of the Duke, who told her that he was hard beset, but that he had one day of rest. They dined together, and then retired. Before parting the next morning they exchanged tokens of their affection. After leaving the Duchess Uther heard that Gorlois had been killed. Later Hierna came out into the meadow to make terms with the King, and told him that she had a brave husband at home. Uther then told her the truth, and finally persuaded her to marry him. The meeting of the Duchess and the disguised King in the castle is described in detail. In the Historia it is barely mentioned. Uther learns the news of his enemy's death from messengers who came to the castle to inform the Duchess of it. The messengers are naturally much amazed to see her sitting beside one in the Duke's semblance. Uther returns to his army to hear what had happened, and later goes back to Igerne and persuades her to marry him. 
Geoffrey translated the prophecies of Merlin, which constitute The Book of Merlin. Further support is lent Geoffrey's claims to translation by the existence of The Prophecy of Ambrosius Merlin concerning the Seven Kings, which was translated by John Cornwall from a Welsh source independent of Geoffrey's, but which contained much the same material. This original is also lost, but similar material actually existed in Wales during the same century and was attributed to Merlin, as Giraldus bears undisputable testimony. Giraldus also makes it plain that these prophecies were common property and were used by the people and the bards alike. Such evidence should be conclusive of itself.

Unfortunately none of the Welsh originals for the translations of Geoffrey, John, and Giraldus are extant. But other Welsh poems of a predictive nature ascribed to Merlin have survived. They present at least one problem of some difficulty, for all of the manuscripts are of later date than II35. It is, however, certain that they contain material that is much older. It is not unreasonable to infer that the poems which discuss early historical events antedate the twelfth century. ${ }^{45}$ In The Dialogue between Merlin and Taliessin, ${ }^{45}$ Myrdin (the Welsh cognate of Merlin) appears as a prophet conversing with Taliessin and foretelling the future. This poem ends rather significantly for the present study:

Since I, Myrdin, am next after Taliessin, Let my prediction become common.

A group of predictive poems relating to Cadwallader mention Merlin as a prophet. These refer to the expected return of Cadwallader and his alliance with Conan of Brittany. ${ }^{46}$ An echo of this legend is found in The Book of Merlin in the

${ }^{45}$ W. F. Skene, The Four Ancient Books of Wales containing The Cymric Poems attributed to the Bards of the Sixth Century, 2 vols., Edinburgh, I868, vol. I, p. 222, 225. Volume one contains essays on various subjects connected with these poems and translations of the poems themselves. The Welsh texts and notes are in volume two.

${ }^{46}$ Geoffrey takes no cognizance of this legend in the Historia, for he chronicles the death of Cadwallader in chapter 18 of book twelve. For the political relations of this story consult Villemarqué, loc. cit., passim. 
passage, "Cadwallader shall call unto Conan and receive Albany into his fellowship." But a more intimate relation exists between The Book of Merlin and the Welsh poems. The distinguishing feature of the former is the unusual animalsymbolism. Something very similar to this is found in the kind of epithets bestowed by the bards upon their patrons, as Urien, 'Eagle of the Land.' The fact that Gildas ${ }^{47}$ uses the same kind of epithet in his Epistle shows that it occurs in Welsh literature from the earliest times. If, as Skene ${ }^{48}$ suggested, Maglocune and Cuneglas are referred to in Poem XVII of the Red Book of Hergest as 'The Dragon from Gwynedd' and 'The Bear from the South,' the continuance of the epithets so late and the substitution of them for the names of the kings would strengthen the conclusion. This substitution of the epithet for the person occurs as early as the sixth century, for Gildas refers to Boadicea as the 'deceitful Lioness' without naming her, and to the mother of Constantine as 'the unclean Lioness of Damnonia.' This is what has happened in the case of the prophecies. The epithet has been used as a vatic symbol. Similarly, in the Welsh poems preserved, the epithet is frequently used without the man's name but with no prophetic intention.

In The Book of Merlin the animals employed as symbols, once or oftener, are the Boar, the Lion, the Eagle, the Lynx, the Goat, the Ass, the Hedgehog, the Heron, the Fox, the Wolf, the Bear, the Dragon, the Bull, and the Owl. Not all of these are used as epithets in the poems examined. Some epithets are found in the poems that are not employed in the prophecies.

The animal names common to the poems and the prophecies are used in various ways in the poems. The Bear is applied directly as an epithet to Adan and to Cyndylan, and as a simile

${ }^{47}$ Gildas addresses Constantine as 'the tyrannical whelp of the unclean Lioness of Damnonia,' Aurelius Conans as 'the Lion's Cub,' Cuneglass as 'the bear and charioteer of the bear,' and Maglocune as 'the dragon of the island.' Novatus, a persecutor of the Christians he calls 'black Hog.' In the historical part of the Epistle he calls Porphyrius 'mad Dog,' and refers to Boadicea as the 'deceitful Lioness.' He also likens Vortipore to the leopard, pardo similis.

${ }^{48}$ Skene, vol. I, p. 2 I 3. 
to Caradawg 'whose stroke in battle was like the woodland boar's,' and to Bleiddiad who had the 'aspect of a boar.' The Lion is used as a symbol for an unnamed chief in The Satisfaction of Urien, and is applied to another nameless prince about to be baptized, in Poem XVII of The Book of Taliessin. It is used several times in the Gododin poems symbolically for other unnamed kings. The Eagle is used in the same poems as a symbol for a nameless king whose descendant is referred to as 'Grandson of the Eagle of Gwydien,' and in an address to Urien for that king himself. It is also bestowed as an epithet upon Urien. The Wolf is used as a symbol in the Cuhelyn and Poem XIV of The Black Book of Caermarthen, and as an epithet with the names of Brann, Ceawy, and Cyndylan. The Bear is the epithet of Cynan and Cadwaladyr. It is found as a symbol in Poem XVII of the Red Book of Hergest, in the Hoianau, and in Poem LIII of The Book of Taliessin. The Dragon is used as the epithet of Angor, and as a symbol in Poem XVII of The Red Book of Hergest, in Poem LIII of The Book of Taliessin, and in the Gododin poems. The Bull, Bull of the Battle, Bull of the Conflict, occurs more frequently than any previously mentioned. It is used as the epithet of the Privet in The Battle of the Trees, of Llwid Llednais in The Verses of the Graves, and of Eithynin in the Gododin poems, in the Gorchan of Tudviwch, in The Verses of the Graves, and in Poem XXXIII of The Black Book of Caermarthen. This enumeration, except in the first case, does not include the similes and metaphors in which the animal images are used. A similar use of animal imagery and epithets is to be observed in the tales of the Mabinogion. But sufficient citations have been made to show clearly the relationship.

The Book of Merlin contains several obscure passages in which the symbolism is effected partly by the use of trees and forests. The passage telling of the expulsion of the foreigners is followed by the sentence, "Cambria shall be filled with gladness and the oaks of Cornwall wax green." 49 One sentence further is the passage, "From Conan shall issue forth the warlike Boar that shall try the sharpness of his teeth in the forests of Gaul. For the greater oaks shall he stub each one, but unto

49 Evans, I77; Giles, I23. 
the smaller shall he grant protection." ${ }^{50}$ Towards the close of the third chapter is the allegory of the tree with three branches, the North wind, and the birds. ${ }^{51}$ In the fourth chapter is an account of the nesting of the Heron of Calaterium in an oak on a mountain in the Valley of Galabes. ${ }^{52}$ Later, after an overflow of the Thames, a conflict between the oaks of the forest and the rocks of the Gewissi is described. ${ }^{53}$ The prophecy also narrates the transformation of three thundering bulls into trees. $^{54}$ All these passages seem utterly unintelligible until one finds that in The Battle of the Trees the conflict is described as if the opposing parties were really trees. In The Spoils of Taliessin, furthermore, the Oak is used as the symbol for the prince addressed by the poet. These forests, oaks, and other trees may thus be interpreted as referring to individuals. The Oak, in one of whose branches the Heron nests, may refer to some family into which the Heron, a princess, marries. The Branch of the Oak would then be the husband.

It has been shown that Geoffrey of Monmouth did not imitate any of the continental prophecies that preceded The Book of Merlin. It has been shown, furthermore, that external evidence indicates very clearly that Geoffrey translated The Book of Merlin from the Welsh. Internal evidence has shown a close relation between the conventions of the prophecies and the conventions of Welsh poetry. But none of the Welsh poems preserved is the original of The Book of Merlin. The repetition of motives throughout the prophecies seems to indicate that the original was a collection of fragments, or episodes, that had been put together with as much continuity as possible. Since prophetic fragments were sung by the bards, as Giraldus says, they were in all probability metrical. If the arrangement of the material in The Seven Kings is an indication, this original was perhaps in dialog form, and contained apostrophes, and ejaculatory expressions of the prophet's emotiors. But beyond this little can be determined of the form of the original.

\footnotetext{
${ }^{50}$ Evans, 177; Giles, 123.

${ }^{51}$ Evans, I78; Giles, 123-4.

${ }^{52}$ Evans, 181 ; Giles, 125.

${ }^{53}$ Evans, 183; Giles, 127.

${ }^{54}$ Evans, I86; Giles, 128.
} 


\section{CHAPTER THREE}

The Major Monuments of the English Traditions; Welsh, Scottish and Irish Prophecies

It is not practicable to continue the study of the prophecies chronologically, for they soon become too numerous and too short, and deal with too many different things to be treated and discussed in a general study. Attention can be given only to the major monuments that rose during the flourishing period of the type. These are The Prophecy of the Six Kings to follow King John, The Prophecy of Thomas à Becket, The Prophecy of John of Bridlington, and The Prophecy of Thomas of Erceldoune. In the form in which these prophecies have come down, they belong to the latter half of the fourteenth or to the early fifteenth century. The Six Kings and Erceldoune prophecies are older in their origin. After the fifteenth century it became the habit to collect several prophecies into one, or to give new material lengthier treatment.

The Prophecy of the Six Kings to follow King John, ${ }^{1}$ henceforth to be referred to as The Six Kings, presents a more continuous literary history than the others, for it is derived ultimately from The Book of Merlin. It appears at its different stages in Latin, Anglo-French, and English. An English version in riming verse is very important because of its historical connections, for it is the prophecy that was used against Henry the Fourth by the Percy-Glendower faction, the 'skimbleskamble stuff' of Shakspere. It purports, as its name implies, to foretell the events in the reigns of the six kings who succeeded King John.

The account of the kings begins with the Lamb of Winchester (Henry the Third). According to Merlin, this Lamb is to have a white chin, sothefast lips, and a heart wherein Holi-

${ }^{1}$ Printed as an appendix in Jas. Hall's edition of Laurence Minot's Poems, London, I887. Echoes of this prophecy are found in two of Minot's poems. 
ness is written. While he is truand, an insurrection is to be raised in his realm by a wolf of a strange land, but it is to be quelled by the aid of a Red Fox from the Northwest. At his death his heir shall be in a strange land, and the realm shall abide for a time without a ruler.

The Lamb is to be succeeded by his heir, the Dragon (Edward the First), whose disposition is of mercy and severity mingled. This Dragon shall have a beard like a Goat and a sweet breath. He is to frighten Wales from North to South, and conquer many countries. A people of the Northwest, led by a wicked Greyhound, shall make an incursion into the country, but they shall be defeated by the side of the sea, and dwell for a time in many perils as stepchildren. This Dragon shall foster a Fox that shall raise a war against him not to be ended in his time. This Dragon in his lifetime is to be considered the best knight in the world, and is to die on the borders of another country. Then shall the land dwell in trouble as a stepchild without its mother.

After the Dragon shall succeed a Goat (Edward the Second) who has horns of silver and silk, and a beard like a buck; whose breath betokens hunger, death of the people, loss of land, and much other trouble; and in whose days, Merlin says, whoredom and adultery shall be prevalent. This Goat shall come out of Carnarvon and go to another country to get the Flower-of-Life (Isabella of France). During his reign so many people shall die that strangers shall be bold against him. Upon an arm of the sea a battle shall be fought in a shieldshaped field. A Bear of the Goat's blood shall raise war against him. The Goat, clad in a Lion's skin, shall at first make resistance successfully with the aid of a people from the Northwest, and avenge himself on his enemies. But he shall end his days in pain and sorrow. In his time shall flourish an Eagle of Cornwall, named Gaveston, who shall die for his pride and presumption.

After the Goat shall come a Lion (Edward the Third), who shall be fierce and terrible in heart, whose countenance shall be full of pity and justice, whose breast shall be a slaking of thirst for those that love peace and rest, whose tongue shall 
speak truth, and whose bearing shall be meek as any lamb. In the beginning of his reign he shall have trouble to punish miscreants, but he shall at length make his people as meek as a lamb. He shall be called Boar of Prosperity, Nobility, and Wisdom. He shall come out of Windsor, and shall go through four lands whetting his tusks. He shall go even to the Holy Land without opposition. Spain, Aragon, and France shall acknowledge his power. He shall whet his tusks against the gates of Paris, and shall wear three crowns before he dies. $\mathrm{He}$ shall meet his end in a far country and be buried beside three kings.

After the Lion, or Boar (for he is called both in the poem) shall come an Ass (Richard the Second) with leaden feet, a steel head, a brass heart, and an iron skin. This Ass shall govern his land in rest and peace, and shall be praised for his well doing. Then he shall give his land into the governance of an Eagle, who shall govern it well until, overcome with pride, he is slain by the sword of a brother. The control of affairs is then to revert to the Ass, who rules well and in whose time all good things are plentiful.

Afterwards a Mole (Henry the Fourth) shall be ruler of the land. This Mole shall have a hide as rough as a goat's skin, and shall be accursed of God for his misdeeds. He shall be greatly praised until he is overcome with pride. Then shall a Dragon raise war against the Mole. A Wolf, seeing the Dragon hard pressed, shall come to the Dragon's aid. Then both shall be joined by a Lion from Ireland. This combination is then to defeat the Mole and drive him from the land, leaving him only an island in the sea where he shall pass his life in great sorrow and strife, and finally lose his life by drowning. England shall be divided into three parts between the Dragon and the Lion-and, it would seem, the Wolf, who, however, is not mentioned in the partition. Then shall England be known everywhere as the Land of Conquest, and the heirs of England lose the heritage.

The framework of The Six Kings is taken from Geoffrey of Monmouth's The Book of Merlin. King John was identified by various chroniclers as the Lynx of the earlier prophecy 
under whom Neustria (Normandy) should lose both the islands. John's loss of Normandy fulfilled this prophecy in an inverse manner. But the overthrow of the Normans and the restoration of the native dynasty remained unaccomplished. According to The Book of Merlin Conan succeeded the Lynx. This part of the prophecy was passed over, and the Lamb of Winchester substituted for Conan with no explanation. For the Boar who was to stub short the Oaks of Gaul, according to the earlier work, the Dragon was substituted. The Goat, the Boar, and the Ass are identical in both prophecies, but the Mole is not to be found in the earlier one. Beyond the mere identity of certain symbols the two have little in common, although the main theme of the Goat episode in The Book of Merlin is mentioned in The Six Kings. The Boar in the latter seems to be a combination of the Boar who was to stub the Oaks of Gaul, and the Boar of Commerce in the former.

It is not to be expected that all versions of this prophecy should agree in minor details. Just as this poem differs from The Book of Merlin, so the versions differ from each other. Some contain more material than others. Some agree in general subject matter but not in minute details. In some cases genuine history has caused a correction of earlier mistakes. Detailed study, however, is impracticable in this place and has therefore been relegated to an appendix. ${ }^{2}$ The consideration of this poem's importance in political history must be postponed to the next chapter which deals with the interrelation between history and the prophecies.

The Prophecy of John of Bridlington ${ }^{3}$ is, perhaps, the most interesting example of the genre because of its length and elaborateness, and the artistic care with which every little detail of the plan has been worked out. It is a Latin poem provided with a commentary, a dedicatory epistle, and three introductory essays, or preambles as they are called by the

${ }^{2}$ See Appendix I. The date of this poem is uncertain. It is found first in a fifteenth century manuscript, but the vague description of the end of Edward the Second's reign would indicate that it was written before his death in 1327 .

${ }^{3}$ Thomas Wright, Political Poems and Songs, London, 2 vols. Rolls Series, I859, vol. I, p. I23 f. 
writer himself, all likewise in Latin. Since the commentator gives the impression that he is not the author of the poem, it was first thought that two men were concerned with the prophecy. John of Bridlington was accredited with the vaticinal portion; a certain John Ergome with the commentary, dedication, and essays. ${ }^{4}$ But there seems no valid reason for doubting that both parts are the work of one man whose name is unknown.

The date can be fixed with fair accuracy. The work is dedicated to Humphrey de Bohun, Earl of Hereford, Essex, and Northampton, Constable of England, and Lord of Brecknock, who succeeded to these honors in II6I and died in II 72.5 The poem must have been written between these dates. A reference $^{6}$ to the visit of David Bruce to Edward the Third shows that it must have been written later than I 63 . An allusion to an irregular election of an Archbishop of Canterbury ${ }^{7}$ would seem to place the date of composition before 1366 when Simon de Langham was chosen, ${ }^{8}$ apparently with no irregularity, to succeed Archbishop Islip, who had just died. Langham was, however, deposed in 1368 , a fact which answers well to an alternative mentioned in the commentary on the passage relating to the Archbishop. If the reference were to this event, the poem would have to be dated later than 1368. But the author of the prophecy would then be anticipating somewhat, for the other events described in the same stanza all took place in 1363. This episode of the Archbishop is best considered a case of genuine prophecy accidentally fulfilled. The fact that no historical event later than 1363 , unless perhaps this obscure matter relating to the Archbishop, is referred to leads to the conclusion that the prophecy was written about 1364 .

The introductory essays are interesting in themselves. The second of these enumerating the various tricks of prophetic disguise has been discussed in the first chapter of this study. The third is little more than a brief outline of the poem. In

${ }^{4}$ Supra.

'Dictionary of National Biography, vol. 5, London, 1886, p. 3 Io.

B Bridlington, III ; iii.

'Bridlington, III ; iii.

${ }^{8}$ Dict. Nat. Biog., vol. 29, 1892, p. 74 ; vol. 32, 1892, p. 99. 
the first the commentator says that there are four things (causae) to be observed in regard to the prophecy: the events it narrates, and the various customs and manners it discusses (accidentia); the method of composition (causa formalis); the origin of the prophecy (causa efficiens); lastly, the purpose with which the prophecy was written (causa finalis).

The accidentia he explains as the events of war; the customs and manners of the realm, such as the obedience paid the laws, contempt and neglect of the laws, lust, avarice, and other vices and virtues; the manners of the lords and councillors of the king and of the whole people; lastly, the matters that concern the whole people, such as changes in costume, changes in the coinage, pestilences, famines, and similar calamities. As to the causa formalis three things are to be noticed: the literary form, which is verse instead of prose; the manner of presentation, which is by means of obscure, prophetic (prophetialis) terms; and the order of events, in which the past is narrated and the future is forteold. The causa efficiens, says the commentator gravely, is the Holy Spirit which, according to the general opinion, dictated the prophecy in a vision to a regular canon, who committed it to writing. In regard to the causa finalis three things are to be observed. The first is the benefit to be derived from the knowledge of prophecies, for he who knows prophecies is forewarned for his own benefit, can warn his friends, and will be prepared to share in any prospective good fortune. The second is the satisfaction which comes to a man from three sources: because he knows something of which his fellows know nothing; because by knowing one prophecy he is the more able to interpret others; because he can appreciate thereby the love of God who took pains to forewarn him. The third thing to be observed is the honor that is obtained by the knowledge of prophecies. Men who are acquainted with them have more knowledge than other men, and because of this superior knowledge are considered more fit to rule.

The plan of the prophecy is very methodical. It is divided into three sections (divisiones). Each section is divided into chapters (capitula) which are so short that they are really 
stanzas. The first section, after an introductory stanza, narrates the events from the accession of Edward the Second to the preparations for the battle of Crècy; the second covers the sixteen years from 1344 to 1360 ; the third begins with the year 1360 and professes to tell the history of the Black Prince as King of England until he is acknowledged King of France. This last section contains the matter that is purely vaticinal. A commentary is provided for each chapter, but in later versions was discarded with the result that any desired interpretation was given any passage.

The various tricks of disguise used in this poem have been discussed in the first chapter. For so long a prophecy the animal symbols are comparatively few. None of the symbols are taken from The Book of Merlin, as in The Six Kings, except the Goat which stands for Edward the Second. Edward the Third is constantly spoken of as the Bull, taurus, except once when he is called the Kite, milvus. David Bruce, the King of Scotland, is called the Crab, cancer, because he had at crucial moments a habitual tendency to retrograde action. The Black Prince after his accession is called the Cock, gallus. This is perhaps a pun on the two meanings of the Latin word gallus, for the prophet declares that the French in his reign submit to the English and accept him as king. The commentator says in the second essay that gallus is used for the King of France. ${ }^{9}$ On different occasions various noblemen of England are referred to more or less indefinitely as oxen, gray old dogs, lions, calves, leopards, and bears. The allies of the Scottish King in a war against England prophesied for the last years of Edward the Third's reign are called by the names of fishes, such as the Turbot, rumbus, which is used for the King of Denmark.

The poem contains a great deal of etymologizing in that the component parts of an English compound word are frequently translated into Latin; thus mare mortis for Mortimer.

${ }^{\circ}$ Neither Philip, John, nor Charles is spoken of in the poem as gallus. But the plural galli often occurs for the French, who are also called Franci. The phrase pulli gallorum occurs often enough to indicate that galli means cocks. 
The parentage of Edward the Third is made very obscure by the use of this trick. The Latin of the passage runs,

Ex hirco taurum redimita per aurum,

Ex auris aurum ventis componitur.

Hircus, the Goat, stands for Edward the Second. Redimita per aurum is a phrase used for Isabella of France, the mother of Edward the Third. Ex auris aurum is a phrase used for the son, aurum, of wealthy parents, auris. Ventis aurum is an etymologizing of Windsor, Edward the Third's birthplace; ventis translates the English winds, aurum the final or, which is taken to be French. The Duke of Lancaster becomes longum castrum. Carus vicus stands for the Earl of Derby; terra vada for the Earl of Hereford. The Battle of Halidon Hill is referred to as a battle at mons sacer, the Battle of Mountjoy in France as at mons gavisus. Frons ursina is hard to recognize as Berwick, which the commentator calls Bearfront also. The punning translation of names, such as penetrans for Percy, is a similar trick.

Because of its numerous conventions the poem almost defies adequate translation, for in most cases the ambiguity of the original cannot be preserved. The line $\mathrm{e}^{10}$

Milvi caedentur, cuculi silvis capientur,

taken from the account of the Scottish invasion of England during the later years of Edward the Third's reign, is an example. The trouble lies with milvi and cuculi which are not really substantives but numerical symbols confusedly arranged. Thus milvi stands for MLVII, and cuculi for CCLXI.

A better idea of the poem can be got from connected passages. The second chapter of the second section is typical of the whole. As nearly as it can be translated, it runs thus:

\footnotetext{
"Now wars increase, thrice three battles arise: Thou Maid, Dear Star of the Sea, bear Thou the standard. Twice $d u x$ shall strike vix with three hundred allied (MCCCLXVI). The false Phi. (Philip) will flee, he will not aid the fallen. A King, a Duke, and a Soldier become common after the slaughter. The heads of ducum (either nobles or MDCX) adorned with jewels will be broken : no one shall save his life by yielding

${ }^{10}$ Bridlington, III : vi.
} 
his jewels. No one crosses the Glad Mountain (Mountjoy) without disaster: the Grandmaster himself shall not be saved. The horns of the just shall be against the Galli, and the English shall delight in the delicacy of the grape. Striving to destroy the English lands by war, the plough (culter) will be a witness. David, the adulterer, will be ruined. Suspicor, the priest, (Zouche) and penetrans (Percy) true to his name, will penetrate the bowels of the Scottish warriors. Wide wounds will be made with the narrow sword. For Luke, the physician, will not be friendly to the Scots (a reference to a battle fought on St. Luke's Day.) For with the Devil as chief they will be conquered on Luke's Day. At nova villa with the cross as a witness (Neville's Cross) will they lie hidden without light. Victory will not be slow with a small band, clean in mind, when Christ carries the standard. The holy horned ones (bishops whose mitres were horned), mute as to Divine Law, shall be safe this time under the shield. And it shall not be unsaid that the Scots paid their tribute."

The difficult question of indebtedness to other prophecies now arises. It has been shown that the animal symbols are not taken from The Book of Merlin. The greater part of the poem is evidently a tour de force. The writer, however, may have made some use of existing materials, but the evidence on the point is very slight. The Cock was employed in vaticinal literature as a symbol for France or the King of France as early as 1358 , at least eight years earlier than the composition of this poem. ${ }^{11}$ The Crab was used in the Giraldian Collec-

11 "Herwib acordip Merlyn Ambrose bat such angusche is nyze for as by hem in be tyme of be myscheif of be kok bab we clepe fraunce bat schal be distroyed by be sixte of irlond be witt is our kyng wib his children." The Last Age of the Church, ed. J. H. Todd, Dublin, I840, p. xxxiii. This was written in the year 1356 according to the date given in the context, p. xxxi. The unknown author quotes four lines from the prophecy known from the opening words as Galiorum levitas. Gallus is used for France in the Versus Northmannie.

Anglia transmittet leopardum lilia Galli

Qui pede calcabit cancrum cum fratre superbo

Ungues diripient Leopardi gallica regna

Circulus invictus circumdabit unde peribunt

Anglia regnabit vasconia parta redibit

Ad juga consueta leopardi flandria magna

Flumina concipiet que confundent genetricem

Lilia marcescent leopardi posse vigebit

Ecclesie sub quo libertas prima redibit

Huic babilon metuet circis (?) omnibus vanterit 
tion, but its interpretation is unknown. It is used as a symbol for the King of Scotland in the Versus Northmannie. ${ }^{11}$ The Bull had occurred frequently in The Book of Merlin, but no instance of its use for Edward the Third has been found in the course of this study. The unusual method of expressing numbers had been used before. The Latin prophecy beginning,

"Tolle caput Martis bis cancri luna suum dat

Hiis ter junge decem tercaput adde iovis,

is an example. The two lines express in a round-about way the year 1283 for which the prophecy was written. Examples of Latin numerals so arranged as to form words have not been found elsewhere.

Bridlington is interesting also for its relationship to later prophecies. The Cock in the North, ${ }^{13}$ beginning

"Quen be cokke in be northe has biggid his neste

And buskid his bryddes and bowned him to fle"

seems to take its beginning from the two lines

"Tempore brumali gallus nido boreali
Pullos unabit, et se volitare parabit."

But the resemblance ${ }^{15}$ between the two passages does not prove

Acon Ierusalem Leopardi posse redempte

Ad cultum fidei gaudebunt se redituras

(Ms. in British Museum, Arundel 57, f. 4. a.)

This prophecy is older than $\mathbf{1 3 2 0}$. It is quoted in an exposition of several prophecies in the same manuscript beginning on the next folio. This date is given in the second line of the exposition: Ward (Cat. I, 308) thought the date should be $\mathbf{I} 340$, basing his conclusion on an erasure in the date. The erasure does not prove that the date given is incorrect, for the original may have been wrong. Mistakes are frequently erased. A reference to Robert Bruce as still alive, a few lines further, shows that the exposition must have been written before his death in I329. I 320 cannot be far wrong.

13 Ward, loc, cit., I, 31.

${ }^{13}$ See note $I$, chapter I.

${ }^{14}$ Bridlington, III, ix.

${ }^{15}$ This resemblance was noted by Brandl (The Cock in the North, 1177) who considers the English lines a translation from the Latin, since the unknown author of The Cock in the North refers in his poem to Bridlington. 
the English a translation of the Latin. The Latin verses might equally as well have been translated from an English original which has also served as the basis of The Cock in the North. The Prophecy of the Fysshes ${ }^{16}$ is certainly a close metrical adaptation in English of the account of the war made on the Bull and his allies by the Crab and his allies, who are all fishes.

Thomas à Becket, during the fourteenth and fifteenth centuries, was credited with numerous prophecies. Many of these are in Latin, and concern the ampulla found in the Tower of London by Richard the Second. These are closely connected with the political events attending Richard's deposition, and will therefore be discussed in the next chapter. Some prophecies relating to the reign of Edward the Third and attributed to Becket are contained in an alliterative poem written in the vernacular. $^{17}$ In the manuscript the poem is entitled Saint Thomas of Canterbury. Its abrupt beginning, "Thomas rides from Rome," and the contents of the first fifty lines might indicate that it is a part of a longer poem which dealt with the travels of Thomas à Becket. There is a much longer version of the poem in a Northern dialect, perhaps Scottish, which, however, lacks the first twenty-eight lines. ${ }^{18}$ The shorter will be referred to as the Hatton version, from the manuscript in which it is found, and the longer for a similar reason, the Cambridge version. The two differ somewhat in minor details, but the substance is the same as far as the Hatton extends. The poem was apparently written shortly after the Battle of Poitiers in 1356 , for this is the last historical event that can be identified in it. ${ }^{19}$

The passage the poet seems to attribute to the prophet does not occur in the Bridlington prophecies, and nothing like it is to be found there. Besides this mere mention of the name there is no proof that the author knew anything of Bridlington, though its popularity makes it probable. This resemblance was noted in this study two years before Brandl's publication.

${ }^{16}$ Printed, Brandl, The Cock in the North, Sitzb., 1187.

${ }^{17}$ Ms. Bodleian, Hatton 56, 45a-46b.

${ }^{18}$ Printed by Lumby, Bernardus de Cura rei familiaris, from Ms. Cambridge, Kk, 5. For Hatton version see Appendix 2.

${ }^{19}$ Brandl, Paul's Grundriss, Strassburg, 1892, II, 661, thinks it written to refresh confidence in the aging Edward the Third. 
According to the poem, Becket left Rome and went to Pisa where he found masons at work upon a tower of alabaster near a neglected shrine of the Virgin. Thomas called the attention of the master workman to the shrine and the image of the Virgin within it, and gave him money to provide means of pilgrimage to it. From Pisa he went to Basel where he entered a church to celebrate mass. But when he reached for his missal, he discovered that he had left it at Rome. While he was at a loss to know what to do, a wonderful book fell upon the altar. When he left the church he found that some one had stolen his bridle, whereupon he bade the people get him another. From Basel he went to Avignon where he knelt and kissed the ground, and in reply to a question from young Warrenne prophesied that the place should at some time be the seat of the papacy.

The material dealing with English affairs begins with Becket's arrival as Poitiers whither he went from Avignon and where he was entertained in the house of a burgess. $\mathrm{He}$ asked who owned a castle he saw under construction, and was told that it was being built at the command of King Charles. Thereupon Thomas began to prophesy. There shall come, he said, two Boars from England and ruin the tower and the town, of whom one shall do much damage to the king and put him to flight, and the other pasture himself in the choicest fields of the kingdom. The people who heard these wonderful words reported them to King Charles, but he declined to cease the work 'for drede of a boar.' The Boar, said Thomas, shall be born of French and English blood and shall be matchless on earth. Thomas then went out into the fields and bade the masons build three crosses. At the first cross the King of France, said he, shall fall and lose his crown, at the second Archbishops and other church dignitaries shall die, at the third the crown shall fall in a battle of beardless boys. Young Warrenne made game of the prophecy and rexed Thomas sorely. Here the Hatton version ends.

The Cambridge version continues for one hundred and four lines further, and describes in greater detail the Boar's career in France. The burning of Abbeville and the battles of Mount- 
joy, Caen, Calais, and Valois are mentioned. Then an invasion of the Boar's realm by a King from the North and the Boar's revenge at Berwick are prophesied. After the capture of Berwick a battle is predicted at Boulogne in which a twoheaded Bird with fifty thousand men sides with the enemy. The capture of Paris and the defeat of the Bird follow. Afterwards, said the Saint, the Boar shall win Milan, Lombardy, and the Bird's three crowns, and then go on a crusade to the Holy Land, whence (it seems) he is not to return. After his departure the land is to be ruled by women or be desolated by a pestilence. Marvels such as red rain occur until the people recognize Christ. Sir Edmund of Abingdon, who has not been mentioned previously, interrupts by remarking upon the lateness of the hour. An angel in blue bids Becket close the book, from which it now appears that he had been reading, and carries it up to Heaven. Becket and his companions resume their journey. So the poem closes.

Neither version of this poem is complete. Even a composite of the two would seem incomplete. The very beginning is abrupt. The reference to Becket's companions without previous description might indicate that a portion of the poem has been lost, in which the circumstances of the travels were described and the experiences of the party in Rome narrated, or perhaps that the original of both versions was a transcript or paraphrase of a part of a longer work. Such tags as 'this book tells' would indicate that the writer had his eye on a larger work. ${ }^{20}$ Neither version is a part of the other, for they differ too frequently and too widely. The Hatton version names at first two Boars, which can stand only for Edward the Third and the Black Prince. The Cambridge version mentions only one Boar. According to it King Charles abandons the

${ }^{20}$ Cf. lines 40 and $4 \mathrm{I}$ Hatton Version;

"This Thomas went on his wey as he wele myght

ij days journey as be boke tellis."

At times these references to 'The Book' are made to the Book of Prophecies from which Becket is reading. Of course one knows that it was a convention of Middle English poetry to refer to a mythical Book as authority. This reference may amount to nothing more. 
work at Poitiers, and Becket finishes it in order that the Boar may have a place of rest when he invades France. The prophecy regarding the tower is not made by Becket, but is found by the workmen engraved mysteriously on a stone. A prayer of Becket's to Our Lady is different in the two.

This poem is more closely related to the Six Kings than to the other prophecies discussed in this chapter. In both the Boar is used for Edward the Third with the combined characteristics of the two Boars in The Book of Merlin. But in this prophecy the metaphor of the Boar and his tusks is carried further in the references to the damage done by the tusks. The beginning of the Boar's reign is described in both prophecies in similar terms. According to The Six Kings,

"He sall have trey and tene in biginning,

To chistise misdoers of wrang lifing.

And als thurgh felnes sebin sall he seke,

Till he have made be folk als lamb to be meke";

according to the Becket prophecy,

"This bore in his barnhede shall many noians abide $\&$ in be myddes with peynes be prikked on every side bis bore shall he makeless for mercy him folowes after bat he pas the pase of many grete sorowes."

Both allow the Boar three crowns but not the same ones. In The Six Kings they seem to be the crowns of Spain, France, and Aragon. In the Becket prophecy they are not named, but they seem to be won from the two-headed bird. ${ }^{21}$ The Crusadeepisode, deriving originally from the Last-King-of-Rome story, is found in both, but this poem makes more detailed mention of Famagosta, Cyprus, and Jaffa as places visited on the

${ }^{21}$ The Two-headed Bird probably stands for the Emperor of the Holy Roman Empire, who is referred to as the Eagle in another prophecy on the French Wars, The Prophecy of the Lion, the Lily, and the Son of Man. A version of this was printed by Todd, Last Age, p. lxxxiv. The Eagle from the East comes at first to the aid of The Son of Man (Edward the Third, according to an interpretation in a manuscript described by Ward, Cat. I. 318) but loses his crown to the Lily (France). When the Lily lost it, the Son of Man was crowned with it. In this prophecy, the Son of Man takes the cross and makes a crusade to the Holy Land. 
way. The greater part of the prophetic material, however, seems to have been written for the occasion. Other animal symbols than the Boar are few. The King of France is referred to by name as Charles, but which of the French Kings so named one cannot say. ${ }^{22}$

Thomas of Erceldoune has received more attention than any of the poems just discussed because of the romantic material in the first fytte, but the prophetic material in the third and fourth fyttes has been neglected. The reason for this neglect is probably that too little English vaticinal literature has been published to give much assistance in studying, and that material for the study of the romance has been easily accessible. The question as to the origin of the romantic material does not concern this study, and must, therefore, be passed over. ${ }^{23}$

According to the story, Thomas, while lounging under a tree by Huntlybanks one fine morning in May, saw a lovely lady come riding towards him holding three grayhounds in a leash. He mistook her for the Virgin, and ran to meet her at Eildon Tree. He accosted her as the Queen of Heaven, but was told that she was quite a different personage. Then Thomas, overcome with her beauty, entreated her love, which she granted. But she lost her beauty in consequence and required Thomas to do penance by accompanying her and dwelling with her one year. Accordingly, she led him into an underground passage at Eldonhill knee-deep in water. After three days she brought him into a beautiful orchard, the fruit

${ }^{2}$ The only Charles that ruled in France after the Carolingians and before the accession of Charles the Fifth in 1364 was Charles the Fourth, the last of the Capetians in the direct line, whose death in 1328 was one cause of the Hundred Years' War. It was, perhaps, this name Charles that led Lumby to think the poem referred to the wars of Henry the Fifth. The name may have been substituted in the fifteenth century for some other name that stood there originally. The poem may have been used in the fifteenth century to glorify Henry the Fifth, but it was undoubtedly written much earlier.

${ }^{23}$ Those who are interested in the romantic features will find an excellent treatment of the subject in Josephine M. Burnham's A Study of Thomas of Erceldoune, Publications of the Modern Language Association of America, vol. 23, p. $375 \mathrm{f}$. 
of which she forbade him to pluck. There she bade him halt and look at a castle in the distance, which she gave him to understand was her home. While she spoke, she underwent a transformation and regained all her lost beauty. After blowing her horn she led the way to the castle, where she and Thomas were heartily welcomed. Thomas dwelt in the castle in happiness until one day the lady told him that it was time to return. He prepared himself for the journey, and followed her back to Eldonhill. But as the Lady turned to leave him, he asked her to give him a token and to tell him a wonder. She gave him the prophecies.

The events prophesied in the second fytte are historical and can be easily identified. The battles of Halidon Hill, Falkirk, Bannockburn, Kinghorn, Duplin Moor, Hexham, Durham, and Otterburn are named or referred to in evident terms. The younger Baliol, David Bruce, and Robert Steward are named as kings of Scotland at different times. Symbols are few. The Goshawk is used for David Bruce, the Raven for Edward the Third, and the Tercelet for Baliol and various unnamed Scots.

The events prophesied in the third fytte are unhistorical. A battle is prophesied at Spinkard Clough where the Scots are victorious, and another at Pentland Hill, after which the English invade France. Apparently they return to worry Scotland, and fight three great battles, the first between Seton and the sea, the second on Claydonsmoor or Gladsmoor, the third at Sandyford. At the second battle three kings are slain, and a raven comes flying over the moor followed by a crow. At the third battle the English seem from the context to be led by a Bastard from the South. This Bastard is to die in the Holy Land. At the time of his death Scotland is to be in a deplorable condition. The lords of the land are all slain, and their heiresses marry their former servants. Thomas then asks after Black Agnes of Dunbar, who had once put him in prison, and is told that she will meet an inglorious fate in London. The Lady after this prophecy says farewell and leaves him. The poem closes with a short supplication to Christ ' to bring us to Thy hall on high.' As in the second fytte symbols are few, being limited to a Raven, a Crow, and a Bastard. 
The vaticinal matter in the second fytte is easily enough understood, and was evidently manufactured for the occasion. The five battles, the three kings, the Raven, the Crow, and the Bastard in the third fytte are not so easily explained. They seem unhistorical, at least they have not been identified. They do not occur in the earlier prophecies, but are important episodes in later versions of this same material made as late as I5 $5 .^{24}$ The expectation of the battles lasted long. Barnet $(\mathrm{I} 47 \mathrm{I})^{25}$ and Prestonpans (1745) ${ }^{25}$ were both identified as Gladsmoor. Spinkard Clough was considered fulfilled in Pinkie Cleugh (1546). ${ }^{25}$ The three kings, who are here nameless, appear in the later versions as the Kings of Spain, Denmark, and Norway. Bridlington's prophecy concerning the assistance given the King of Scotland by the King of Denmark may have helped to perpetuate this particular episode. A short passage found in only one manuscript ${ }^{26}$ describes the armorial bearings of four great lords who take part in the war against the Scots; the first bears a red lion in his banner, the second a ship with a golden anchor, the third a wolf carrying a naked child in his mouth, and the fourth a bear bound to a stake. ${ }^{27}$ In some versions the number of these lords is increased to eight, but these four remain the same. In the other versions also they are not enumerated together, but appear at different parts of the narrative. The Raven and the Crow are found only in some, but the Bastard occurs in all.

The poem contains only one episode that shows the influence of earlier material. The Lady in describing the hopeless condition of Scotland after the Battle of Sandyford, bursts into tears and says,

\footnotetext{
"Bot for ladyes, sall wed laddys ynge,

When bair lordes ar ded awaye.

He sall hafe stedes in stabill fed,
}

24 See Murray, Thomas of Erceldoune, Appendices $\mathrm{i}$, ii and iii, and Brandl, Thomas of Erceldoun, p. II8, for these variant versions.

${ }^{25}$ Murray, supra, xlii, xliii, lxxviii.

${ }^{26}$ Thornton Manuscript, Murray, supra, p. 38.

${ }^{27}$ Brandl, supra, p. 140, endeavors to identify these lords, but can fix with certainty on only one symbol, the Bear and the Staff, which stands for Warwick. None of the other symbols fit exactly the heraldic bearings of the families he names. 
A hawke to bere appon his hand,

A lufly lady to his bedd:

His elders byfore had no land."28

This is a development of a line in an older prophecy attributed to Thomas of Erceldoune, who had made it in answer to a question of the Countess of Dunbar as to when the Scottish wars should cease. His answer runs : ${ }^{29}$

"When people have made a king of a capped man;

When another man's thing is dearer to one than his own;

When Loudyon is Forest, and Forest is field;

When hares litter on the hearth stone $;^{30}$

When Wit and Will war together;

When people make stables of churches, and set castles in styes;

When Roxburgh is no burgh, and market is at Forwylie;

When the old is gone and the new is come that is worth nought;

When Bannockburn is dunged with dead men;

When people lead men in ropes to buy and sell;

When a quarter of 'indifferent' wheat is exchanged for a colt of ten marks ;

When pride rides on horseback, and peace is put in prison;

When a Scot cannot hide like a hare in a form that the English cannot find him;

When right and wrong assent together;

When lads marry ladies $;^{31}$

When Scots flee so fast that for want of ships they drown themselves;

When shall this be? Neither in thy time nor in mine;

But (shall) come and go within twenty winters and one."

In its setting and framework this poem resembles very much a Northumbrian ballad relating to the Scottish wars. ${ }^{32}$ The story is related in the first person by a traveler. The fairy

${ }^{28}$ Brandl, supra, 114; Murray, supra, 44.

${ }^{29}$ This is a modernized version printed by Murray, p. 1xxxvi. The original is printed at page xviii. Murray apologized for the modernized version, saying that he had been asked so frequently what the older version meant that he considered it necessary.

${ }^{30}$ Referred to by Andrew Lang in Ballade of Autumn, Ballades in Blue China, London, 1888 , p. 48 .

${ }^{31}$ Lads in its original meaning of ' farm-hand,' Murray, lxxxvi.

${ }^{22}$ Printed Langtoft's Chronicle, Rolls Series, London, 1866, 2 vols., vol. 2, appendix from a manuscript of the late thirteenth or early fourteenth century. See also Ward, I, 300. 
motive is introduced, but the fairy is a 'little man' and not a 'lady gay.' The ballad begins,

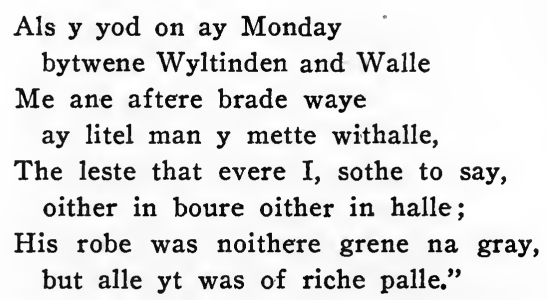

The dwarf bade the traveler stop and wait for him. When the two had met, the dwarf led the way into a beautiful garden where lords lolled at ease and ladies sang in the corners. The traveler interrogated his guide concerning the Scottish wars and their result. He was told that a Mole was in Scotland on guard, and that a Boar lay south of the Humber, bound fast in a pasture by fools and watched by the Mole. At length the Boar should escape from his den, but he was to be held long by a Leopard. After a great battle fought south of the Tweed the Boar should win the land, although the Lion should go to fetch it. $\mathrm{T}$ beside an $\mathrm{L}$ connected with $\mathrm{Ed}$ as a thread should be the bailiffs.

This ballad is unsatisfactory in every way, for little can be made of it. The stanzas and the lines seem badly confused and disarranged. But it shows one thing,-a prophecy dealing with Scottish Wars was written in ballad meter and with a fairy motive introduced. Nothing in the ballad, however, is repeated in Thomas of Erceldoune. The dwarf-motive occurs in two later versions of the same material, The Prophecie of Thomas Rymour, ${ }^{33}$ and The Prophecies of Rymour, Beid, and Marlyng. ${ }^{34}$ In both the visit to the garden is omitted, and the prophecy occurs as a vision. Both contain references to the battles of Gladsmoor, Sandyford, and the one between Seton and the sea.

It has been said previously that the romance in Thomas of Erceldoune had received the most study. Professor Child ${ }^{35}$

is Murray, Erceldoun, p. 48.

${ }^{34}$ Supra, p. 52. Cf. the opening stanza of the ballad, The wee, wee man.

${ }^{35}$ Quoted by Murray, supra, p. xxvi. 
once wrote that the second and third fyttes were additions to the romance made by an unskillful hand. Murray dissented. ${ }^{36}$ Since the later versions of Erceldoune omit the romance and revert to the setting of the ballad, it seems probable that the earliest form contained only the vaticinal elements, and that the romantic elements were a later addition. It is true that the Lady appears in the later poems clad in much the same fashion as in this poem, but she is the Queen of Heaven and makes no prophecy. The second fytte can easily be explained as the necessary amount of history told as prophecy, such as was conventional in vaticinal writing. It is true that no part of the prophetic material in the ballad recurs in these later poems. But the printed version is incomplete, and is, perhaps, not the only version. ${ }^{37}$

The date of Thomas of Erceldoune is uncertain. Murray and Brandl concur in the view that it was written in $I 400$. Murray $^{38}$ bases his conclusions on his interpretation of the passage,

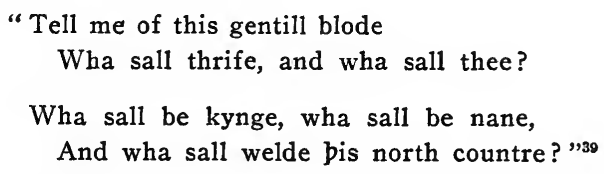

He thinks this a question as to the conflicting claims of the Bruce and Balliol families, which would not have been made after the extinction of the Balliols. The passage probably refers to the Bruce-Baliol quarrel, for it comes early enough in the second fytte which deals with the Wars of the Scottish Succession. But it seems scarcely sufficient evidence to prove the date.

Brandl's theory is much more elaborate. He finds ${ }^{40}$ that the

${ }^{36}$ Supra, xxvi.

${ }^{37} \mathrm{Cf}$." "betwene the walcoen \& the wall this lytyll man mett with me, tolde me this proffecy all, And what tyme it shuld be."-The last stanza of The Prophisies of Rymour, Beid, and Marlyng.

\footnotetext{
${ }^{38}$ Murray, Thomas of Erceldoune, xxv.

${ }^{39} \mathrm{Brandl}$, Thomas of Erceldoun, p. 94.

${ }^{40}$ Brandl, supra, 30 .
} 
key to the whole prophecy is contained in next to the last stanza of the first fytte which reads:

\footnotetext{
"Ferre owtt over zone mountane graye, Thomas, my fawkon bygges his neste,

A fawkon is an erons praye, Forthi in na place may he rest."
}

He understands this as referring to a conflict between two birds, and finds that all the symbols in the poem are taken from the names of birds. He interprets the Heron as Henry the Fourth, who while Duke of Lancaster had been referred to in political poems under the symbol. In other prophecies of this same period Henry was called aquila, 'egle,' and 'fawkon.' The Bastard 'born in South England' Brandl considers also a bird and likewise interprets it as Henry the Fourth, but he finds no examples of its use for the same man in other political poems. If the Heron is a king of England, it is evident from the lines quoted that the falcon must be a king of Scotland. Finding that David Bruce is called in the prophecy Falcon and Goshawk, ${ }^{41}$ Brandl considers his interpretation proved correct. Since the battles named in the third fytte never occurred in any historical invasion of Scotland, he reaches the conclusion that the poem must have been written before Henry's invasion in August, I400. He then argues that it must have been written after Henry's accession and while there was a rumor of the invasion, and fixes the date as I400.

The poem may have been written in $\mathbf{1} 400$. There is no satisfactory proof either that it was or was not written then. One must confess, however, that Brandl's theory is not very satisfying. Its plausibility lies in the degree of correctness with which the symbols have been interpreted. Its weakness lies in the interpretation of the poem. In the longer prophecies, such as those described in this chapter, great consistency is observed in the use of symbols, only one being used for one individual. This is true also of the shorter prophecies. A poet who could

${ }^{41}$ Brandl, supra, rox. 
plan so carefully the contents of the three fyttes ${ }^{42}$ and could announce so neatly at the close of the first the key to the contents of the other two, would in all likelihood have taken pains not to confuse the symbols. He has done this in the second fytte. But if Brandl's theory be correct, this passage in the first fytte and the whole of the third fytte would be inconsistent with the second and the symbols would be used confusedly. The Falcon, ${ }^{43}$ if it represents the King of Scotland as Brandl supposes, would have to be applied to three different men, David the Second, Robert the Second, and Robert the Third. The Heron would apply to only one man, Henry the Fourth. In the poem, ${ }^{43}$ the Falcon is used only for David the Second. His conqueror, Edward the Third, is not called the Heron but the Raven. It is rather strange, too, that the Heron should be used in this key-note passage as a symbol for a man who is never again called by it, but who is called by another entirely different symbol, the Bastard, when he is introduced. Brandl's theory is interesting, but it does not solve the problem.

Another obstacle to dating the poem at $\mathrm{I} 400$ is the lack of continuity in the narration of events. Throughout the historical parts with one exception the narrative is continuous down to the Battle of Otterburn with which the second fytte closes. According to the order of events in the prophecy, four great battles and an invasion of France occur before the accession of Henry the Fourth, if the Bastard be Henry the Fourth. It is rather strange that the author was so untrue to history, if he wrote in I399 or I 400 after the time for which these events had been prophesied. The only battle predicted to follow the Bastard's accession is Sandyford. One might avoid the difficulty to some extent by referring these battles to Richard the Second's invasion of Scotland in II85-a rather doubtful explanation,--but he cannot so easily explain the invasion of France. Futhermore, Brandl himself confesses that these five battles are all unhistorical.

${ }^{42}$ It is worthy of notice that the poet, while he devoted fifty-nine stanzas to the romance according to Brandl's reconstructed text, divided the prophetic portions rather nicely, giving forty-four stanzas to the second fytte and forty-three to the third.

${ }^{43}$ Line 448 ; Brandl, supra, I0I; Murray, supra, 28. 
If none of the five battles or the invasion of France is an echo of actual events, the last historical event described in the poem is the Battle of Otterburn in 1388. An interval of twelve years in which four of the great battles are fought intervenes before the accession of Henry the Fourth, 'The Bastard,' in 1400. Since the battles are not historical, the third fytte must obviously have been written before the time for which the first of them was prophesied, and therefore before the year I400. It might be argued that the accession of the Bastard should come at the beginning of the fytte and precede all the battles, but there is no manuscript authority for such an arrangement. Furthermore, one of the fundamental conventions of the genre would be violated, for in all the prophecies the imaginary events are described as immediately following the real. In this poem an awkward interval of twelve years would fall between the real and the fictitious. It is not sufficient to say that the real purpose of the poem is to narrate only the history of the wars between England and Scotland. Such is not the case, for Richard's invasion of Scotland is not mentioned and an irrelevant invasion of France is introduced. Moreover, the events in the second fytte are told as if the point of view was from Scotland, but in the third fytte the main interest is in England and in English affairs. It is thus seen that any interpretation of the poem which depends upon the identity of the Heron or the Bastard with Henry the Fourth is unsatisfactory. If the third fytte is purely vaticinal and the Heron in the key-note passage is not Henry the Fourth, the fytte is best considered a ' melange of traditional prophecies' that could have been made at any time, and from which no evidence in regard to the date can be drawn. The poem was written after 1388. As there is no evidence to show that it was written after 1400 , it was probably written before that year. The date cannot be fixed more accurately from the evidence now at hand.

The author of the poem is unknown. Brandl supposed ${ }^{44}$ him to have been an inhabitant of Northern England. Murray $^{45}$ thinks him a Scot and is inclined to believe that he

${ }^{44}$ Brandl, Thomas of Erceldoun, 42.

${ }^{45}$ Murray, Thomas of Erceldoune, xxvi f. 
may have put into his poem some prophecies made originally by the real Thomas of Erceldoune. ${ }^{46}$

The four prophecies discussed in this chapter represent in many ways the genre at its climax. As was said in the beginning of this chapter the prophecies after I 500 become too numerous to be discussed at any length. Many of them will be mentioned in connection with the later chapters of the study. Attention must now be turned to Scotland, Wales, and Ireland, although the prophetic material of these countries can be treated only in the most cursory fashion.

The date at which Scottish prophecy began cannot now be

${ }^{46}$ A real Thomas of Erceldoune seems to have existed in the latter part of the thirteenth century. In 1199 (or II94 as Murray says) Thomas de Ercildoun, son and heir of Thomas Rymour de Ercildoun, deeded to Trinity House, Soltra, the lands which he had inherited from his father in Ercildoun. Thomas Rymour de Ercildoun occurs as a witness to a grant made to Melrose Abbey by Petrus de Haga who lived about 1220. This Thomas is said to have foretold the death of Alexander the Third of Scotland in 1286 . The Harleian prophecy, quoted above, anticipating the Battle of Bannockburn in $\mathrm{I}^{\mathrm{I}} \mathrm{4}$, is said to have been made by Thomas twenty years earlier. These four dates comprise all the evidence, and the last two are traditional.

The prediction of the death of King Alexander was made in answer to a question put him by Dunbar, the Earl of March, as to what another day would bring forth. Thomas fetched a sigh and said to this effect: "Alas for tomorrow, a day of calamity and misery! Before the twelfth hour shall be heard a blast so vehement that it shall exceed all those that have yet been heard in Scotland; a blast which shall strike the nations with amazement, shall confound those who hear it, shall humble what is lofty, and what is unbending shall level to the ground." The news of the King's death announced at dinner the next day was interpreted as the blast foretold by Thomas. One easily sees that the prophecy is only a weather forecast. The story seems not to be older than the fifteenth century, and is first told by Bower in his continuation of Fordun (Murray xiii). It shows only that Thomas was a weather-wise hanger-on of the Dunbar family. The earliest reference to Thomas and his prophecies is made by Barbour (The Bruce, II, 85 f.) in connection with the murder of the Red Comyn. Thomas, whoever he was, wherever and whenever he lived, very early got a reputation for prophetic skill. Tradition assigned him certain prophecies. No more can be said. There is not the slightest evidence that he had any literary ability. The attribution of Sir Tristrem to him is only an attempt to unite a bookless author and an authorless book. 
determined. Barbour's account of the vaticinal tapestry made by St. Margaret naturally inspires doubt. According to $\mathrm{it}^{\mathbf{4 7}}$ this saintly queen had made a picture of Edinburgh castle representing a man scaling the wall, with the motto, Gardez vous de François, which was interpreted as predicting the capture of Edinburgh by a man named François or Francis. Some early prophecy must have been circulated under the name of Thomas of Erceldoune, as frequent references are made by fourteenth century writers to such predictions.

The earliest extant prophecies dealing with Scottish affairs are in Latin, and relate to the wars of the Scottish Succession. They present a singular difficulty, because, being in Latin, one can tell only by the general tone whether any one of them is Scottish or English in origin. Frequently the reader is uncertain whether a prophecy was written by the English, or by the English party among the Scots themselves. The Latin poem beginning, ${ }^{48}$

Ecce dies veniunt, Scoti sine principe funt,

relating to the deposition of Baliol, and the final overthrow of the Scottish kingdom is obviously English in sentiment, and may easily be referred to English authorship. The poem, likewise in Latin, beginning, ${ }^{49}$

Regnum Scotorum fuit inter caetera regna,

outlining the history of Scotland to the accession of John Baliol and prophesying the final defeat of the English inter saxosum fontem castrumque nodosum seems to be Scottish in origin. Another prophecy ascribed to Sibylla is found with it and may be a continuation of it. According to Sibylla a king of the North should greatly afflict the Scots. The aliens in Scotland were also to perish through the trickery of the Scots. In the war a French leader was to fall by the sword of his brother. At length the Welsh were to make a compact with

${ }^{47}$ Barbour, Bruce, $\mathrm{x}, 737-755$.

${ }^{48}$ Langtoft, Rolls Series, vol. 2, p. $448 \mathrm{f}$.

${ }^{49}$ Pinkerton, Enquiry into the History of Scotland, London, 1789, p. 499 f. A version slightly different is printed in Wright and Halliwell's Reliquiae Antiquae, vol. 2, 26, 246. 
the Scots and regain control of the island restoring the old name as the Eagle had predicted. ${ }^{50}$ These verses are frequently attributed to Gildas who, according to this version, drew his inspiration from Christ. The order of the episodes does not remain the same in all the versions.

Prophecies in the Scottish dialect seem not to have existed before the fifteenth century. The extant versions are even more recent. They were collected at the time of James the Sixth's accession to the English throne, and printed in 1603 as The Whole Prophesie of Scotland. ${ }^{51}$ The prophecies in the collection are attributed to Merlin, Bede, Bridlington (spelled Bertlington), Thomas Rymour, Waldhave, Eltraine, Sibylla, Banister, and Gildas. They deal with the history of Scotland in the fifteenth and sixteenth centuries, and employ the usual animal-symbolism, which seems to consist both of heraldic and of arbitrary symbols. Some of the prophecies are in alliterative long lines, some in rime, some in combination of rime and alliteration. One is in prose. With the exception of a few in Latin that cover about two pages they are written in Scottish. In arranging the collection some attempt seems to have been made to preserve a roughly chronological order in regard to the events narrated.

The first prophecy in the collection has no title, but is attributed to Merlin in the first line. The reference in the fifth line to the calling to Cadwallider of Cornwall and to the defeat of the Wolf out of Wales, after which the events of the prophecy occur, connect it with some particular prophecy that has not come to notice. Cadwallider is certainly an echo of traditional material. The real prophecy begins with the supremacy of the Lion in the North, and the defeat of the Bear by a Storm from the South and the Bear's death in a foreign land. Then a Freik fostered far in the South (apparently James the First) returns to the kith and governs it to the discomfort of the Crab and other banished nobles. The death of the king in a fen after a reign remarkable for the covetous-

${ }^{50}$ In a Latin prophecy against Edward the Third (Reliquiae Antiquae, vol. 2, p. 25) this overthrow of the English seems, predicted for $1_{3} 8 \mathrm{I}$. The compact between Wales and Scotland occurs in later prophecies.

${ }^{51}$ Reprinted for the Bannatyne Club, vol. 44, Edinburgh, 1833. 
ness of the chief ruler is then predicted. By far the greater part of the prophecy follows. It is perhaps to be regarded as portraying a chronological succession of events, but any interpretation is doubtful and difficult because of the obscurity of the symbols.

After the fall of the Freik seven years of trouble were prophesied. The Crab and the Cock however escaped the danger. The Raven with his rouping frightened many from Caithness to Cornwall. The Gled climbed to great power and became careless of his lord, the Lion. The Graip wished to grasp absolute power. The crowing of the Cock announced his coming and frightened everyone, especially the false Fox and the Fulmart. A conspiracy was formed by the Raven, the Rook, the Kid, and the Buck. The Birds of the Raven plundered Lothian, and did great harm to the abbeys on the Tweed. A period of lawlessness prevailed for five years when no man trusted another, not even the father his son or the son his father. But peace was finally established by a council called for the purpose, which however did not last long. An Eagle's nesting in a forest disturbed the peace. War was renewed, and a battle fought in the North beside a stock cross which was so completely covered with corpses that the Crow could not tell where the cross stood. Then a Wolf became watchman and remained faithful to his lord, the Lion. A great fleet was got together under the command of the Three Leopards and a fleur de lys. Then a Hunter came from the South and won a battle in Fife..$^{52}$

After an interruption the prophecy is resumed with a version of the Cock in the North. The ballad meter is discarded after the first twelve lines. The Cock built his nest in the North and then prepared to flee, but Fortune at the last moment seems to have favored him. The Moon rose in the Northwest and a Lion, the strongest and best in Britain since Arthur's days, was set free. A dreadful Dragon came to the aid of the Lion, but

${ }^{62}$ The succession of events is interrupted at this point by a prophecy concerning what should happen when the moon was full and when the crags of Tarbat fell into the sea. The writer of the prophecy then presents as proof of his veracity the statement that he had seen the books of Merlin, Bede, and Banister, and had found that they agreed. 
the Bear, apparently the leader of the opposing faction, was joined by a Bull and a Bastard. A Leopard of native stock, a Horse, an Antelope, a Bear, a Brock, and a proud Prince participated in the conflict, which seems to have taken place 'twixt Seton and the sea.' The Lion was injured but victorious in the end, and captured the Fox, the Fulmart, the Piper, the Pie, and the friends of the Fox. 'Troy untrue' (England) trembled for dread of a dread man, for the commons welcomed him and gave him the key to the realm. The Sun and the Moon both shone bright and proceeded safely on their courses, as Bridlington, Banister, Merlin, Thomas Rymour, and others had prophesied. Then it was reported that the Saxons had chosen a king. A dead man rose and was cared for by a young knight, who won a battle in Surrey, went on a crusade, and died in the Vale of Jehosaphat. ${ }^{53}$

${ }^{53}$ Brandl's edition of the English Cock in the North has already been mentioned. He thinks the poem was written in Northern England at the time of the Percy-Glendower rebellion. The Cock he understands as a symbol for Hotspur, the Moon for the House of Percy, the Dragon for Glendower, the Bull for the Nevilles, the Star of Bethlehem for a comet that appeared in 1402 , and the Lion for Douglas and the Scottish auxiliaries. But here he stops with his work of interpretation half done. One would like to know the originals of the Boar (Bear in the Scottish version), the Bastard, the Leopard, the Mole (not in the Scottish), the Mermaiden (not in the Scottish), the Eagle, the Antelope, the Bear, the Bridled Horse, the Proud Prince, the Fox, the Fulmart, the Picard (Piper in the Scottish), the Pie, the friends of the Fox, and the Dead Man. In both versions the Lion is victorious and reigns in peace the rest of his life, a strange prediction to be made by any Englishman if the Lion represented Douglas or any other Scottish power. The Cock and the Moon are completely forgotten after the first two stanzas and can in no way be considered the heroes of the prophecy. They are really of no more importance than the others, the Fox and the Fulmart for example. The reference to London and the English Nation as 'Troy Untrue' would be more consistent from a Scot or Welshman. Furthermore, an English writer of a prophecy on English affairs would scarcely consider it necessary to refer to the English people as "The Saxons.' The Bastard is found as a symbol in this prophecy which must have been written, if Brandl is correct in his conjectures, about the same time as Thomas of Erceldoune. In the latter he interpreted the figure as a symbol for Henry the Fourth, for whom it could as easily stand in this prophecy, but he does not so interpret it.

Since the interpretation of the poem from the point of view of English 
Every prophecy in The Whole Prophecy of Scotland is interesting, but space for detailed study of each is lacking. Episodes are repeated with slight variations in the different poems. References to the battles of Gladsmoor, Sandyford, and 'twixt Seton and the sea' are frequent. The Prophecy of Bertlington contains an interesting episode:

affairs breaks down, and since the English version is undeniably in a Northern Dialect, it seems not unreasonable to suppose that the poem is originally Scottish. If the Scottish authorship is granted, it becomes more easy to understand the poem. The hero is clearly the Lion. In other predictive poems of this same collection the Lion is invariably used as a heraldic symbol for the King of Scotland. If the poem were English, the Lion would have to represent Henry the Fourth, and would be an exception to the other English prophecies. If the Lion is the King of Scotland, his victory is then perfectly reasonable. The Cock and the Moon then become only two participants in a war against the king instead of the protagonists, which they would have to be if Brandl were correct, and which they clearly are not. Furthermore, the Cock occurs at least twice before in the earlier part of the Scottish prophecy in company with the Fox and the Fulmart, and plays the part of a mischiefmaker. If the poem is Scottish, the reference to 'Troy Untrue' and to 'The Saxons' is much more rational.

If Brandl's interpretation is discarded and the poem acknowledged to be Scottish, there is no indication of the date until a proper interpretation is found. The present version may be as old as the English version, or even older.

The Cock in the North may have been the prophecy which Deschamps had in mind when he wrote in his ballade Contre l'Angleterre,
L'aigle venrra des marches d'Aquilon,
$O$ ses poicins, seoir en Northumbrie;
D'un autre lés passera le lion
$O$ ses cheaulx, plains de forsenerie;
Deux lieux prandra qui aront seigneurie
Et destruiront le Nort crueusement;
Et le pais qui anciennement
Fut renommez d'aventures aussi
Se doit tourner a leur destruisement,
Tant qu'on dira: Angleterre fut cy.

The following stanza predicts an alliance between Scotland, France, and ' $1 \mathrm{i}$ ancien Breton' to the undoing of England. The last lines of the stanza quoted seem to echo the end of The Six Kings.

(Cf. Eustache Deschamps, Oeuvres Complètes, ed. Le Marquis de Queux de Saint-Hilaire, Anciens Textes Français, vol. I, Paris, 1878, p. 106.) 
" Of Bruce's left side shall spring out a leaf

As neer as the ninth degree,

And shall be flemed of faire Scotland,

In France farre beyond the sea,

And then shall come again riding,

With eyes that many men may see,

At Aberladie he shall light,

With hempen holters and hors of tree,

On Gosford greene it shall be seene,

On Gladsmoor shall the battle be,

Now Albanie thou make thee boun,

At his bidding be thou prompt

$\mathrm{He}$ shall deil both towre and towne,

His guifts shal stand for ever more."

Later in the prophecy occurs a theme afterwards united with this :

\footnotetext{
"The Frenche wife shall beare the Sonne

Shal welde al Bretane to the sea,

And from the Bruce's blood shall come

As neere as the ninth degree."
}

Lord Hailes analyzed this prophecy, and showed that it was intended originally for John, Duke of Albany, the grandson of James the Second. ${ }^{54}$

The Prophecie of Thomas Rymour deals with the battles of Flodden and Pinkie, and closes with the prediction that the French Wife's Son should become King of Britain. It begins with the narrator's account of his meeting with a bairw upon the way and the vision he saw of a tilting match between Saint Andrew and Saint George, which was interrupted by the intervention of the Virgin. The bairn delivered the prophecy in answer to a question from the narrator as to the meaning of the vision. James the Fourth is referred to as the Red Lion. The Scottish and English leaders are called by heraldic symbols. Allusion is made to the story that James the Fourth did not die at Flodden, and to the expectation of his return.

The rest of the prophecies in the collection, except the last, do not call for special comment. The last $\cdot$ is attributed to

${ }^{54}$ Hailes, Remarks on the History of Scotiand, Chapter III which deals with Thomas of Erceldoune. Published in Annals of Scotland, 3 vols., Edinburgh, 1819, vol. 3, p. 4I f. 
the Queen of Sheba in her character of Sibyl. It seems to have been written by a person acquainted with The Six Kings. The conflict between the Wolf, the Dragon, and the Lion is described. The 'Moldwerp accursed of God' is one of the figures. But new material fitting the different subject is introduced and given the chief importance.

The Scots seem to have learned to write prophecies from the English model. They used the same kind of symbols in the same manner. On occasions they borrowed their material and adapted it to their own purposes whenever they wished. They, perhaps, gave something to the English in the original Erceldoune legend and in The Cock in the North. The accession of James the Sixth to the throne of England seems for a time to have fulfilled the Scottish prophecies. But they were not forgotten, and were brought to light when the changed political fortunes of the Stuarts gave an excuse and the need for the prediction of a bright and glorious career in the indefinite future.

It is now time to give the attention to Welsh prophecies. It has been shown in the second chapter of this book that the Welsh had predictive poems dealing with events earlier than Goeffrey's translation of Merlin's prophecies, but that none of the extant Welsh poems is the original of the translation. It was.shown also by the testimony of John of Cornwall and Giraldus Cambrensis that collections of prophetic sayings ascribed to Merlin existed in the twelfth century, and by the evidence of Giraldus that fragments of these prophecies were in the mouths of all Welshmen. In the course of the discussion as to Geoffrey's sources occasion arose to speak of certain of the Welsh predictive poems that may have antedated The Book of Merlin.

The poems classed by Skene ${ }^{55}$ as Predictive Poems relating to Cadwaladyr are largely traditional; that is, they do not contain references to events of the twelfth or following centuries. They deal chiefly with the return of Cadwaladyr, his coalition with Conan, and the victory of their combined forces over the English. This theme, as was shown in the second chapter, be-

${ }^{55}$ Skene, Four Ancient Books, i, pp. 436-446. 
came traditional and was echoed in The Book of Merlin. It is also repeated in the Welsh poems that contain references to later events, which Skene ${ }^{56}$ has classed as Poems which contain references to Henry, or the Son of Henry. Some of them, as the Afallenau, seem to be newer versions of old material. The method of the prophecy in these poems is not the Galfridian but the direct. An exception to this statement should be made in the case of such traditional symbols as the Bear of Deheubarth which occur at rare intervals. None of the symbols found in The Book of Merlin can be identified in these poems.

Stephens ${ }^{57}$ speaks of other predictive poems which he dates later than II35. They are the Arymes Prydain Vawr (The Destiny of Great Britain), Armes (The Oracle), and a poem attributed to Meugant and forming the link of connection between Cadwaladyr and Conan. So little is said of these poems, however, that nothing can be determined concerning the prophetic method used in them. According to the few indications one can get, it was not the Galfridian.

The Prophecy of the Eagle at Salisbury, as The Giraldian Collection is frequently called, exists in a Welsh version. ${ }^{58}$ 'A prediction of Merlin before Arthur is referred to in the Historia but is not given. It exists in a Welsh form. ${ }^{58}$ The Book of Merlin was translated into Welsh with the rest of the Historia. ${ }^{59}$ The Prophecy of Merddin Emrys occurs in the Hengwrt Manuscripts with other prophecies in Welsh, English, and Latin. ${ }^{60}$ Unfortunately this material has not been accessible for this study. The Welsh had prophecies relating to political events echoes of which can be got in the poems of the bards. Iolo Goch addressed a poem to Owen Glendower in which, in its English translation, this couplet occurs,

"Let hundreds swell their voices high

In him fulfilling prophecy."

${ }^{\text {s6 }}$ Supra, i, 462-496.

${ }^{57}$ Stephens, Literature of the Kymry, p. $285 \mathrm{f}$.

${ }^{6}$ Supra, p. 3 I 3 f.

${ }^{59}$ Ward, loc. cit., I, p. 256.

${ }^{60}$ See Charles Wilkins, $A$ History of the Literature of Wales from 1300 to 1650 , Cardiff, 1884 , p. $202 \mathrm{f}$. for list of Hengwrt Ms.

${ }^{61}$ Translated by Howel W. Lloyd, Y Cymmrodor, vol. 6, p. 98. 
The bards saw in the death of Prince Edward of Lancaster and in Henry Tudor's becoming the representative of the Lancastrian dynasty the fulfillment of the prophecies of Merlin and Taliessin that a Welshman would be crowned in London. They recalled the mysterious prognostications, the brudiau, which foretold that the name of the Welsh deliverer would be Owen. ${ }^{62}$ Rhys ap Griffith used in his uprising against Henry the Eighth a prophecy that James with the Red Hand and the Ravens should conquer England. Red Hand refers to the mythical Owen Llawgoch, Ravens to the family of Dynevor to which Rhys belonged. ${ }^{63}$ This fragment shows a use of the Galfridian method. Sir John Harington quotes in his Tract on the Succession to the Crown (1602) ${ }^{64}$ two Welsh prophecies which he paraphrases for the English reader. The second was made in the time of Henry the Eighth, but the first was written before the time of Sir John's great-grandfather. It promised that a babe marked with a Lion, who should be crowned in his cradle, should unite all the island and recover the Holy Cross.

Despite the scantiness of this material there is evidence that the writing of prophecies flourished in Wales as well as in England. The Welsh bards in their adulatory poems to their patrons refer to prophecies promising a great career for the patron. There was little necessity for the Welsh to prophesy after Bosworth Field, for their fondest hopes were realized in the conquest of England by Henry Tudor, a Welshman, and his accession to the throne of England.

How early the Irish contracted the habit of writing prophecies is not known. Prophecies exist which are attributed to men who lived as early as the second century after Christ, such as the two ascribed to Conn 'of the hundred battles' (died I57), Conne's Ecstacy, and The Champion's Ecstacy. ${ }^{65}$ As a rule, however, the prophecies are attributed to the Irish

${ }^{62}$ W. L. Williams, $A$ Welsh Insurrection, $Y$ Cymmrodor, vol. 16, p. 5 f.

${ }^{\text {e3 }}$ Supra, p. 33.

${ }^{64}$ Reprinted for Roxburgh Society, vol. 99, London, 1880.

${ }^{65}$ Eugene O'Curry, Lectures on Manuscript Sources of Ancient Irish History, Dublin, 1878 , p. 385 . 
Saints, of whom St. Moling and St. Columcille are accredited with the greater number. It is almost needless to say that these attributions are forgeries, for references to actual events show that the predictions were written at much later times. Some of them show evidence of being put together as late as the eighteenth century. ${ }^{66}$ But they refer most frequently to events during the Danish and Anglo-Norman invasions. Those containing references only to the Danish Wars are usually products of the tenth and eleventh centuries. They contain little or no symbolism of the kind that is peculiar to the Galfridian type, so far as one can judge from descriptions of them and from short quotations. ${ }^{67}$

Giraldus Cambrensis testifies that the Irish had written prophecies in his day. He says, "The Irish may be said to have had four prophets, Melingus, Braccanus, Patrick, and Columcille whose books written in Irish are still extant." 68 These prophecies said, it seems, that Ireland would be wholly subdued by the English scarcely before the Judgment Day. Giraldus quotes in substance a prophecy of St. Columba to the effect that a desperate battle should be fought at Down in which so much Irish blood should be shed that men pursuing the Irish would wade in blood up to their knees. According to Giraldus another prophecy ${ }^{69}$ of this Saint's concerning a broken and needy man who should come to Down was fulfilled in John de

${ }^{68}$ Supra, p. 418.

${ }^{67}$ The transformations of Monann in the Irish tale, The Voyage of Brann have, perhaps, echoes of this animal-symbolism.

Stanza, 53. He will be in the shape of every beast Both on the azure sea and on land, He will be a dragon before hosts at the onset, He will be a wolf of every great forest.

54. He will be a stag with horn of silver In the land where chariots are driven, He will be a speckled salmon in a full pool, He will be a seal, he will be a fair-white swan.

Voyage of Brann, Kuno Meyer and Alfred Nutt, London, I895, I, 24-26.

* Giraldus Cambrensis, Expugnatio Hibernica, ii, c. 34 .

${ }^{\circ 9}$ Giraldus Cambrensis, Expugnatio Hibernica, i, 30, 33. 
Courcy, who kept by him a volume of Irish prophecies attributed to St. Columba. Giraldus also quotes episodes from the prophecies of Melingus $^{70}$ concerning a great whirlwind from the East that should lay low the Oaks of Heremon, concerning the submission of the princes of Ulster, and concerning the coming of a man who should be the forerunner of a greater man. The prophecies of Merlin relating to Irish affairs $^{71}$ are best regarded as Anglo-Norman and not Irish in origin. $^{72}$

${ }^{70}$ Supra, ii, 16.

${ }^{71}$ Supra, i, 3, 16, 30, 33, 45; ii, 16, 30, 31, 32.

${ }^{72}$ Attention might be called to Nicholas O'Kearney's The Prophecies of St. Columbkille, Maeltamlacht, Ultan, Seadhna, Coireall, Bearcan, etc., Dublin, 1856 , for a modern version of many of the older prophecies. Those in this volume are, with the exception of the ones attributed to St. Malachi, direct, and have little or no relationship to the Galfridian type. The Prophecies of St. Malachi relate to the succession of the Popes. They are, however, Galfridian, but the consideration of them belongs to the chapter on the Galfridian type in other countries than England. 


\section{CHAPTER FOUR}

\section{The Relation of Prophecies to Political Events}

The life of the Political Prophecy in England extended from the early twelfth century to the late seventeenth century. This endurance in vigor and strength for so long a time was caused by a constant and continuous interest. The type made its appearance under the auspices of men of authority, and throve under the encouragement of the mighty. The Book of Merlin was written at the request of a scholarly bishop by a man who later became a bishop, and in its various forms was dedicated to a bishop, to the son of a king, and to a prince who later became king. The Seven Kings was written by a famous scholar. The Giraldian Collection was made by one of the most cultivated men of his time at the instance of the king himself. Richard the First ${ }^{1}$ sent to consult Joachim, an Italian monk who was reputed a prophet. Bishop Grosseteste ${ }^{2}$ seems to have been interested in prophecies, for Adam de Marisco sent him several. Froissart bears witness to the Englishman's interest in prophecies in his time. An English gentleman once entertained him by showing him a book of prophecies and reading him selections from it. Froissart ${ }^{3}$ also tells of the interest taken by the royal family in a prophecy which was interpreted to mean that John of Gaunt's descendants would at some time occupy the throne. Richard the Second ${ }^{3}$ showed a great interest in prophecies. Henry of Monmouth, the later Henry the Fifth, made a pilgrimage to the shrine of Bridlington; who was regarded as the patron saint of the Lancastrians because the prophecies attributed to him were interpreted

${ }^{1}$ Benedict of Peterborough, R. S., vol. 2, p. I5 I f. Abbot Joachim visited Richard at Messina and expounded to him passages from the Apocalypse.

${ }^{2}$ J. S. Brewer, Monumenta Franciscana, R. S. London, 1858, vol. 2, pp. 146-7. The work sent was Joachim's Exposition of the Apocalypse.

${ }^{3}$ John Webb, Archaeologia, vol. 20, p. 260, 264 f. 
favorably to Henry the Fourth. ${ }^{4}$ The members of the York family were devoted to prophecies. Vaticinations found their way into the State Papers of Henry the Eighth. ${ }^{5}$ Bishop Latimer in 1536 sent Lord Cromwell a Latin prophecy because he knew that the minister 'loved antiquities.' ${ }^{6}$ Many prophecies were addressed to Elizabeth and received by her. The Prophecy of Grebner, given her by the author, found its way to the Library of Trinity College, Cambridge, as will be shown later.

Interest in the type was not confined, however, to the great, but was shared by the common people as well. There is no valid reason for doubting that bits of prophecies were circulated orally among the people of England as they were in Wales. It is true that there is little evidence to support such a statement beyond the almost certain inference that a movement of such endurance and of such importance must have struck root deeply. Popular interest is unmistakable after the introduction of printing. Beginning with Wynkyn de Worde's $A$ Lytel Tretys of the Byrth and Prophecyes of Merlin in $1510,{ }^{7}$ prophecies of Merlin were issued at frequent intervals throughout the rest of the period. ${ }^{8}$ Many of the later prophecies seem to have been nothing more than pamphlets or chap-books. Thomas Heywood's The Life of Merlin (164I) is interesting in this connection, although it is a worthless piece of hackwork. ${ }^{9}$

As a result of such widespread interest the Englishman of the

${ }^{4} \mathrm{~J}$. H. Wylie, History of England under Henry the Fourth, 4 vols., London, 1884-98, vol. 3, p. 334 .

${ }^{5}$ F. J. Furnivall, Ballads from Manuscript, Ballad Society, London, I86872, vol. I, p. 316 .

${ }^{6}$ G. E. Corrie, Sermons and Remains of Hugh Latimer, Parker Society, Cambridge, 1845 , p. 375 .

${ }^{7}$ Reissued by him in 1524 and by John Hawkins in 1533. See Meade, Outlines of the Merlin Legend, supra, p. 1xxiii f.

${ }^{8}$ See The Catalog of Printed Books in the British Museum under the heading Merlin.

${ }^{\circ}$ The full title is The Life of Merlin, sirnamed Ambrosius, his Prophisies and Predictions interpreted: and their Truth made good by our English Annals. Heywood adapts very freely The Six Kings as far as it extends, and then forges his material. Each stanza is followed by several pages of interpretation. 
late Middle Ages and early Renaissance seems to have been proverbial for his love of secular prophecies and his belief in them. "The inglishmen gifis ferme credit to diverse prophane prophesies of Merlyne, and til uthir corrupit vaticinaris, to quhais ymaginet verkis thai gyve mair faitht nor to the prophesie of Ysaye, Ezechiel, Ieremie, or to the evangel," contemptuously wrote the author of The Complaint of Scotland in $1549 .{ }^{10}$ Commines in France sixty years earlier had made a similar taunt against the English when he insinuated, in his account of the meeting between Louis the Eleventh of France and Edward the Fourth of England, that the English were provided with a prophecy for every occasion. The evidence sustains the taunts of the foreigners, for prophecies were both popular and powerful. "Their practical influence throughout Wales and England was very extensive. Like the books of the Italic Cumaean Sibyl they were applied to on grave occasions; they gave sanction to doubtful claims, or animated revolutionary attempts; and were always considered in a state of progressive accomplishment. As these awful denunciations respected political vicissitudes and were directed to rulers as well as to the community they excited the interest of all orders of society; and, when they were cited, at once amazed the gaping multitude and ' with fear of change perplexed monarchs." "11 Edward the Fourth consulted prophecies when in doubt, ${ }^{12}$ and partly on the strength of a doubtful threat contained in one sent a brother to execution. ${ }^{13}$ Noblemen, if they belonged to the great political houses, ${ }^{14}$ collected prophecies relating to the fortunes of their families or kept books containing prophecies concerning the history of the realm. ${ }^{15}$ Ambassadors prefaced

${ }^{10}$ The Complaynt of Scotland, E. E. T. S., extra series, I7-18, London, I872, p. 82 .

${ }^{11}$ Webb, Archaeologia, xx, 252.

12 Martin du Bellay, Memoires, ed. M. Petitot, Paris, 1827, p. 246.

${ }^{13}$ Shakspere, Richard III, I, i.

${ }^{14}$ Earl of Northampton, A Defensative against the Poyson of Supposed Prophecies, London, 1620, p. 125. Cf. Ms. Cotton. Vesp. E. VII (Ward, I, 246). This Ms. seems to be a collection of prophecies made by some member of the Percy family or an adherent.

${ }^{15}$ Froissart, XII, 14, 32. Cf. Webb, Archaeologia, xx, $264 \mathrm{f}$. 
their addresses or pressed their claims with quotations from suitable prophecies. ${ }^{16}$ Books of prophecies were chained to desks in many libraries, and regarded with respect and veneration. ${ }^{17}$

The relation of the prophecies to political events is constant and close. The preceding chapter has shown that it was a convention of the genre to make a review of actual history in prophetic guise before proceeding with the prophecy proper, though the shorter pieces on account of their narrow compass commonly omit the review of the past. Because of this convention the prophecies furnish at the same time a very good vaticinal chronicle of English history from the Conquest to the Commonwealth, and an excellent record of the sentiments of the people at different times. The old Vision of Edward the Confessor was supposed to have foretold the coming of the Normans. The Book of Merlin brings the sequence of events down into the reign of Henry the First. Ganieda's Prophecy in the Vita Merlini covers the civil war between Stephen and Matilda. The Seven Kings leaves Henry, the Second on the throne. This king's troubles with his sons are told in the Giraldian Collection. The reign of Richard the First is represented by the Here Prophecy and by the verses beginning Cedrus alta Libani. ${ }^{18}$ Neustria's loss of the islands, foretold in The Book of Merlin, was realized during the reign of King John. The Six Kings, extending really to seven kings in its fullest and latest version, ${ }^{19}$ furnishes material to some time after the accession of Henry the Fifth. Numerous prophecies relate to the Wars of the Roses, among which might be mentioned Asinus Coronatus, Vulpes et Luna. ${ }^{20}$ The Prophisies of Rymour, Beid, and Marlyng carry the chronicle to some time past the Battle of Flodden in I $^{1} 5$. The break with the old religion is recorded in the piece beginning, "When Rome is removed into England." The Hempe Prophecy carries the enumeration of monarchs through Elizabeth. The accession of

\footnotetext{
${ }^{16}$ Mezeray, Histoire de France, I, 384. (Webb, supra, p. 253.)

${ }^{17}$ Northampton, Defensative, p. I 8.

${ }^{18}$ Ward, loc. cit., I, $3 \mathrm{I} 4$.

${ }^{19}$ Ward, loc. cit., I, 322, no. 24.

${ }^{20} \mathrm{~W}$ ard, loc. cit., I, 3 I 9.
} 
James fulfilled in a way many Scottish prophecies. Lilly's interpretation of the second part of The Giraldian Collection closes the chronicle with the execution of Charles the First and the establishment of the Commonwealth.

Many other prophecies might be added to this list. It is to be noticed that they become more numerous at times of crisis or when patriotic emotion was deeply moved. The French wars of Edward the Third gave rise to numerous vaticinations. The events of these wars were reflected in Becket, The Six Kings, and Bridlington. The same ground is covered by the Latin prophecy called The Lion, the Lily and the Son of Man. ${ }^{21}$ The Prophecy of Joachim, ${ }^{22}$ beginning Egredietur unicornis de plaga occidentali, is on the same period but from the viewpoint of the continent. The Scottish Wars are reflected in The Six Kings, the Erceldoune cycle, the Northumbrian ballad "Als I yod on Monday," and in many Latin prophecies some of which were described in the preceding chapter. The events leading to the deposition of Richard the Second and following the accession of Henry the Fourth called forth many prophecies. Among these may be mentioned the Ampulla Prophecy ascribed to Becket, Filius Aquilae, revivals of Sextus Hibernicus, versions of Asinus Coronatus, ${ }^{23}$ the $V e$ Regalibus, ${ }^{24}$ the later versions of The Six Kings, The Prophecy of the Fishes, and, if Brandl's theory be true, Erceldoune and The Cock in the North. Prophecies seem to have been numerous at the time of the Armada. Many were written while the great Civil War was in progress or after the execution of the king.

The chroniclers, historians, and other people who took any interest in the genre were quick to see this close relation to actual history, as is shown by the fact that fresh interpretations of old prophecies were constantly made during the period. The Book of Merlin was scarcely produced before The Prophecies of Merlin were edited with annotations and interpre-

${ }^{21}$ Todd, Last Age, 1xxxiv.

${ }^{22}$ Bartholomew Cotton, Historia Anglicana, ed. H. R. Luard, R. S., London, 1859, pp. 239-240.

${ }_{23}$ Webb, Archaeologia, xx, 257, prints several of these prophecies.

${ }^{24} \mathrm{Webb}$, supra, p. 256. 
tations. ${ }^{25}$ John of Cornwall's Seven Kings was provided with a commentary. Before the end of the twelfth century a monumental interpretation of The Book of Merlin had been written by Alanus de Insulis, who was one of the most learned men of the century, if he was one with Alain de Lille, the author of $D e$ Planctu Naturae. ${ }^{28}$ Internal evidence shows that this interpretation was probably written between II74 and II79. The commentary is divided into seven books. The first discusses the question whether Merlin was a Christian and answers it in the affirmative. The second contains a consideration of the genuineness of Merlin's inspiration. The author concludes that God made use of Merlin to predict the future as in the case of Job, Balaam, Cassandra, and the Sibyls. In the third book Alanus takes up the question of Merlin's paternity and dismisses the incubus-story, saying that the mother had invented it to hide her own shame. The remaining four books contain the interpretation of the prophecies. Actual history affords the author material down into the reign of Henry the Second. After this point he continues with the prophecies, and attempts to show what sort of things they foretell and to prove these events possible, though he forecasts nothing in particular. Interpretations of certain episodes are found in this book for the first time ${ }^{27}$ so far as could be determined in this study. The book seems to have been fairly well known and the author to have enjoyed a reputation for great wisdom. Rupescissa $^{28}$ is said to have used this book as a basis for a commentary which Telesphorus professed to have used.

The chroniclers also formed the habits of quoting prophecies as fortelling events or happenings which they were narrating. Ordericus Vitalis set the example. Several examples from Giraldus Cambrensis were quoted in the preceding chapter. Frequently a chronicler seems to have taken the

${ }^{25}$ Lincoln Cathedral Ms. A. 46, I2 c. Described by $\mathrm{H}$. Schenkel in Biblioteca patrum latinorum Britannica, Kais. Akad. D. Wissensch. Sitzb. philos. hist. Klasse, vol. I $3 \mathrm{I}, \mathrm{Wien}, \mathrm{x} 894$, p. $6 \mathrm{I}$.

${ }^{26}$ Histoire Littéraire de France, vol. 16, p. 4I 7 f.

${ }^{27}$ For instance, the episode relating to the 'newcomers' (Evans, I75; Giles, I22) interpreted as applying to Stephen.

${ }^{28}$ Kampers, Kaiserp., p. 237. 
prophecy and the interpretation from some predecessor's account of the same thing. Matthew Paris quotes several fragments in this way. ${ }^{29}$ The episode, "The half shall be round," 30 is quoted by Higden, Trivet, Rishanger, and Walsingham, not to mention others, and occurs in the Brut $y$ Twysogion, under date of 1279. The episode relating to the slaughter of the Bulls by the Lion's Cubs was referred by Roger of Hoveden and Benedict of Peterborough to the revolt of young Henry against Henry the Second. These are only typical instances; other prophecies as well were quoted when occasion served. A Latin prophecy on Sextus Hibernicus, beginning Ter tria lustra tenent cum semi tempora sexti is quoted in the Eulogium Historiarum with linear interpretations. ${ }^{31}$ Adam of Usk quoted Bridlington, The Giraldian Collection, and The Book of Merlin. The list might be carried to a greater length.

The life of a prophecy, it is evident, was not limited to a few years following its production. Many episodes in The Book of Merlin survived for centuries. The second part of The Giraldian Collection was translated into English and used as a genuine prophecy three hundred and fifty years after its first appearance. A popular prophecy was not allowed to die. Fulfillment of various episodes in it was expected and announced on the slightest occasion. A prophecy that had proved untrue was revised so as to conform to historical fact. The Six Kings was for two hundred years interpolated and revised. Sextus Hibernicus, or Hiberniae, was confidently expected for even a longer time. How a germ of a prophecy could grow has been made evident in the case of Erceldoune.

History made the prophecies by furnishing them the material to deal with. The early examples of the type established the form and its conventions. The truly vaticinal portions were first intended to give only an imaginary portrayal of what might happen in the future. The events predicted were indicative of the writer's wishes and desires, or reflected the spirit and sentiments of the times. The earlier prophecies are therefore to be

\footnotetext{
${ }^{29}$ Matthew Paris, Chronicle, R. S., vol. 2, p. 4, 388, 463; Chron. Maj., vol. I, p. 260 .

${ }^{30}$ Evans, I75 ; Giles, I 21.

${ }^{81}$ Eulogium Historiarum, R. S., vol. I, p. 4I7 f.
} 
considered exercises in a clearly defined literary genre, written to satisfy a desire to produce something like that which someone else had done and to give play to the writer's speculative ingenuity. Ganieda's Prophecy, which is pure history, can be nothing but a literary exercise. The Book of Merlin, inasmuch as it is a translation, belongs in the same category. It is true that Geoffrey included in it the Cadwalader-Conan episode which promised the expulsion of the foreigners and the restoration of Welsh hegemony, but no one accuses him of any sinister motives against the Norman dynasty. The Prophecy of the Fishes, which is nothing but a translation and adaptation of two chapters of Bridlington, must also be considered a literary exercise.

The events predicted in these literary prophecies concern either the personal career of the king-and the nation only incidentally as it is represented by the king,-or the national interests of the people as a whole. Becket deals chiefly with the King of England, for whom it foretells a brilliant and glorious career of universal victory which ends in a successful Crusade. The same can be said of The Lion, the Lily, and the Son of Man. In Anglia transmittet Leopardum ${ }^{32}$ the King is still of chief importance, but the interests of the nation as represented in the person of the king are given more attention. On the other hand the Latin Verses against Edward the Third, a Scottish prophecy, is concerned with the national sentiments of the Scots. They are promised not only freedom but also complete triumph and perpetual supremacy over their foes. The king does not enter into it. Bridlington because of its elaborateness and complexity of form must be regarded as a literary prophecy. But it is rather encyclopedic in its scope. In addition to narrating actual events and to picturing the possible future the writer recorded the faults of the king and the miseries of the people. But he did this rather to admonish the king, for he predicted the king's ultimate repentance and reformation.

The present writer cannot subscribe to the belief that every political prophecy was written with some particular and well-

\footnotetext{
${ }^{32}$ Printed in note II to chapter three.
} 
defined purpose in view. Brandl thinks that Becket was written to restore confidence in the aging Edward the Third. Such may be true. But it is highly improbable, one must confess, that a king whose armies abroad had just won a conspicuous victory at Poitiers and whose army at home had recently retaken Berwick should need the assistance of a prophecy to regain the confidence of his subjects. The Anglo-Norman version of The Six Kings dates as early as the late thirteenth century. Actual history is portrayed as far as the reign of Edward the Second. Thereafter the account of events is pure prophecy. But the events predicted in each reign relate to the personal career of the king, and are not of a nature to influence opinion in a crisis unless they might be quoted in favor of some monarch during some insurrection.

It is difficult, in the case of any single prophecy, to say that it was never used to influence opinion in behalf of any political faction. The absence of any record of such use is no proof. All that can be done is to take cognizance of those cases in which the records furnish evident proof, and to consider the others according to the purpose for which they were written, as far as one can judge from an examination of their contents. Many prophecies which were produced merely as literary exercises were afterwards quoted as bearing upon a given situation and as promising a definite result. The CadwaladerConan episode was used innocently enough by Geoffrey, but detached from The Book of Merlin, it was perhaps circulated among the Welsh to further the ambitious designs of princes who wished to be recognized as the Cadwalader of the prophecy. The prediction concerning Edward the Third that he, as a Boar, should whet his tusks against the gates of Paris seems to have been known in France and to have been used by the French faction allied to him. ${ }^{33}$ Episodes from The Book of Merlin relating to a victorious maiden who should dry up the poisonous wells of Winchester ${ }^{34}$ and to a damsel who should come out of the Forest of Canute ${ }^{35}$ were applied by the French

${ }^{33}$ Froissart, Oeuvres, ed. Baron Kervyn de Lettenhove, 25 vol. Brussells, 1870-77, vol. I7, p. 2 I6.

${ }^{34}$ Evans, 179; Giles, 124.

${ }^{35}$ Evans, 179 ; Giles, 124 . 
to Jeanne d'Arc. ${ }^{36}$ The episode in The Book of Merlin seeming to foretell the coalition of Scotland and Wales and their victory over England ${ }^{37}$ lingered into the sixteenth century. It is used in most of the Scottish Latin prophecies in conjunction with the episode promising the restoration of the ancient name to the island. A form of it, "King James with the Red Hand and the Ravens shall conquer all England," was used in the rebellion of Rhys ap Griffith in 1531. ${ }^{38}$ The Filius-Aquilae episode from the Giraldian Collection, written originally with reference to Henry the Second, was revived in the interest of Henry the Fourth, who in other prophecies was frequently called the Eagle. Glendower in his letters to foreign princes seeking their assistance referred to prophecies which he seemed to fulfill, but he did not name or quote them. ${ }^{39}$ Numerous other instances might be mentioned, particularly in the later period in the case of such episodes as The French-Wife's-Son and The Cock in the North, but these are sufficient to make the point clear.

The prophecies were written at first purely as literary exercíses. After they had been in existence some time they were quoted as bearing upon certain political issues. But in the course of time when factions grew up in the government of England and political rivalry became more intense, prophecies were written and circulated deliberately as active political propaganda. They were either completely new creations, or revivals of old material revised to fit the exigencies of the occasion and the interests of the faction they were designed to further. As such they were used by certain factions in the government, or by the government itself, in support of certain policies.

One of the earliest propagandist prophecies is the poem which is called, for want of a better name, Adam Davy's Five

${ }^{36}$ Villemarqué, Myrdhin, p. 323 f.

${ }^{37}$ Evans, 175 ; Giles, 122.

${ }^{38}$ W. L. Williams, $A$ Welsh Insurrection, $Y$ Cymmrodor, vol. I6, p. 33.

${ }^{39}$ A. G. Bradley, Owen Glendower and the Last Struggle for Welsh Independence, London, 190 , p. I6I. 
Dreams about Edward the Second. ${ }^{40}$ It is properly a series of visions. Although it contains no animal-symbolism it is interesting because it is evidently propagandist.

The dreams cover a period extending over a year. In the first dream Davy saw King Edward crowned with gold standing before the high altar of Canterbury and strongly assailed by two armed knights who beat the king severely. The king endured the blows without returning them, but suffered no wound. When the two knights had gone, four radiant bands of light, red and white, sprang from his temples far and wide into the country. This dream occurred on Wednesday before the Feast of St. John (August 29).

On Tuesday night before All Saints' Day (November I) Adam dreamed that the king was chosen Emperor of Christendom (Emperor of the Holy Roman Empire). A second dream apparently on the same night (the author counts the next dream the third of the series) showed the king clad in a gray cloak, without shoes and hose and with bloody legs, riding as a pilgrim towards Rome where he soon arrived. This dream seems to have caused Davy some anxiety, for at the sight of the king's legs, which were red as blood, his heart wept for great dread.

The next dream occurred some six weeks later on a Wednesday night before St. Lucy's Day. Davy thought that he was in Rome, and that he saw the Pope and King Edward, clad in gray, both newly ' dubbed.' The Pope wore his mitre, the king the crown of the Holy Roman Empire. This dream closes with the prayer that the king might overcome his enemies and 'all wicked Saracens in every place.'

The fourth dream occurred on 'worthingnight.' ${ }^{41}$ Davy dreamed that he came into a chapel of the Virgin, and that he saw Christ unloose His hands from the cross and declare that He was going on a pilgrimage with the king who should con-

${ }^{40}$ Edited by F. J. Furnivall, E. E. T. S., 69, London, 1878 : reprinted by O. F. Emerson, A Middle English Reader, New York, 1905, pp. 227-232. Emerson omits $d o$, the last word in line 18, p. 23I, and all of what should be line 3, p. 232 .

${ }^{41}$ This date has not yet been identified. 
quer the heathen. The Virgin declared that the Saviour's will was hers, and prayed God to attend the king night and day.

On Wednesday in 'clean Lent' a voice bade Adam, who describes himself at this place as Marshal of Stratford-at-Bow, write down these visions and show them to the King. $\mathrm{He}$ demurred because of the darkness, but light from Heaven showed him the way, and he set forth eastward.

On Thursday next the birthday of the Virgin (September 8), it seemed to Adam that an angel took the king by the hand. The king stood before the altar clothed in red, and red in countenance. Two other points the author says are not shown in the poem, but that he will disclose them only to the king. The angel came to him and threatened him with punishment unless he told this dream.

Very little is known of this poem. It has no title in the manuscript. The king Edward has been identified as Edward the Second because in the poem he is addressed as King of England and Prince of Wales. The first and third Edwards never bore the second title. The ill-fated son of Henry the Sixth and Margaret of Anjou never became king. Edward the Fourth was never called Prince of Wales. The prophecy could not have been written about Edward the Fifth. The poem is older than the sixteenth century. Edward the Second is the only king that answers all requirements.

No exact date has ever been set for the poem, but Emerson ${ }^{42}$ seems to have expressed the general opinion when he said that it was probably written soon after Edward's accession to the throne in 1307. The reason for such dating seems to be that after the first years of the reign no one in his right senses would have prophesied such a brilliant future for Edward the Second. But this is really no reason at all. There is danger at this late day, especially in the case of prophecies, of seeing things too much in perspective. Edward's contemporaries did not all consider him weak and inefficient. He had friends and supporters who came to his assistance in the time of trouble. Many of them had doubtless never heard the stories told of him, and many who had heard did not believe.

${ }^{42}$ Emerson, supra, p. 314. 
The first difficulties with Thomas of Lancaster were rather the result of family quarrels. Lancaster was the king's cousin, and the queen's uncle by the half-blood, and except the king was the only Prince of the Blood grown to man's estate. An enthusiastic partisan of the king who was ignorant of the stories or disregarded them could under the circumstances have prophesied almost anything.

The predictions which seem so highly improbable are that Edward should become Holy Roman Emperor, and that he should make a successful crusade. Neither of these would have appealed to the patriotic Englishman of that time as so very unlikely. Richard of Cornwall, brother of Henry the Third, had been elected Emperor after the death of Henry the Fifth by one faction of the Electorate, and had actually exercised sovereign power in a part of Germany. Edmund of Lancaster, the uncle of Edward the Second, had been elected King of Sicily, but had never made any effort to make good his election. As for the second prediction, the age of crusades had not entirely passed. Edward the First had been on a crusade when his father's death left the throne vacant for him. English kings as late as Henry the Fourth dreamed of recovering the Holy Sepulchre.

The prediction regarding the election as Emperor becomes less unreasonable when one recalls the state of affairs in Germany. At the death of Albert the First in $\mathrm{I}^{3} \mathrm{I} 3$, Lewis of Bavaria was elected by one faction, Frederick of Austria by another. Both exercised the imperial authority in their respective domains until $\mathrm{I}_{322}$ when Frederick was defeated and captured by Lewis. Even then Pope John XXII refused to acknowledge Lewis, and declared the imperial office vacant. It was, therefore, quite possible to prophesy the election of an Emperor who should be acceptable to the Pope. Such is just the prophecy that is made in the Dreams where the king is described as being on friendly terms with the Pope. ${ }^{43}$

\footnotetext{
${ }^{43}$ A wilder prophecy is made of Edward the Second in the Exposition of the Verses of Gildas concerning the prophecy of the Eagle and the Hermit, ms. Arundel 57, 5 a. This pretends to be an interpretation of several prophecies, but is really a prophecy itself. The date $i_{320}$ is given in
} 
The date of the poem cannot be determined with any great certainty. Adam's prayer that the king should be victorious over his enemies would certainly indicate that the poem was written after the opposition to the king had become rather strong. Gaveston was beheaded in I312. Lancaster became all powerful in I3I4. The election of Edward as Emperor is more reasonable if prophesied to occur after the death of the Emperor Albert in I3I3. Pope Clement the Fifth, who died the following year, recognized neither Lewis nor Frederick. The seventy-sixth line of the poem, "Bop hij hadden a newe dubbyng," seems to imply that the pope who should consecrate the King in his new dignity had himself been crowned only recently. Clement the Fifth died in I3I4, but no successor was elected until I3I6 when John XXII was chosen. If this line has anything to do with papal politics, it was probably written during the interregnum. The consecration according to the Dreams took place in Rome. But the new Pope when elected resided in Avignon, the second of the Babylonian Captivity which had been begun by his predecessor in 1305 . The author would seem to have written with the expectation that the new Pope when chosen would reside in Rome.

Nothing has so far been known of the author except what can be got from the poem itself. He gives his full name, Adam Davy, once and speaks of himself twice as Adam the Marshal of Stratford-at-Bow. In both instances he speaks as if he

the piece itself. References to Robert Bruce in the context show that it must have been written before Bruce's death in I329. The Queen must be Isabella of France, for she is called Gallica.

According to this prophecy, Edward the Second should make his eldest son King of Scotland. He was to quarrel with the king of France, make war on him, conquer him, and make one country of the two kingdoms. Shortly after the Queen was to die. Edward was then to marry a German princess who should become the mother of a mighty soldier whom Merlin had called 'the Lynx penetrating all things.' Edward was later to make an invasion of Spain and after conquering it, to pass over into Africa. After conquering all Africa, the Holy Land, Persia, and Babylon, he was to be met at Tholmaida by envoys from the Pope asking him to become Holy Roman Emperor. He was not only to receive this title, but was also to become Emperor of Constantinople as well and master of the world. The rest of the prophecy concerns his sons after his death. 
were a well-known person. He was at one time supposed to be the author of other poems that occur in the same manuscript, but this view has now been discarded. An Adam the Marshal, seemingly a man of some importance, is mentioned in the Patent Rolls at the close of Edward the First's reign and during that of Edward the Second. On March 6, r306, license was granted for the alienation in mortmain by Adam le Mareschall of Cirencester to the master and brethren of the Hospital of St. John the Baptist, Cirencester, of a messuage and a moiety of a virgate of land in Cirencester, Northcote, and Preston. On July 26, I3 13 , pardon for a fine of two hundred pounds was granted the abbot and convent of Cirencester for acquiring in mortmain in the preceding reign small parcels of lands, tenements, mills, shops, and messuages with their appurtenances in Cirencester from a number of men among whom Adam le Mareschall is mentioned. On October 24, I3I5, a similar pardon for a similar offense was granted the abbot and convent of Cirencester. Adam le Mareschall is again one of the men from whom land and property were acquired. A commission of oyer and terminer dated May 16, I316, names Adam le Mareschall as one of a company who with the Abbot of Cirencester hunted rabbits on lands at Tillbury, Gloucestershire, belonging to Peter de Brewosa.

So far there is nothing to connect Adam the Marshal with the court or with Stratford. He seems to have had property in Circencester and the neighborhood, and to have been on friendly terms with Adam de Brokenborough, Abbot of Cirencester. A patent of September 28, I3I4, granting safe conduct until Christmas for Walter de Gawey and Adam le Mareschall whom Henry de Beaumont was sending on business to the Isle of Man, brings him into greater prominence. Henry de Beaumont was a kinsman both of the King and of the Queen. Edward had made him King of Man in I312. Adam le Mareschall must have been a trustworthy man of some importance to have been sent on such a mission. Another patent dated April 21, I3I6, shows that he and Sir Robert de Bardleby became surety that certain traders sent out by Stephen Aleyne, a prominent London merchant, would not take the goods to the 
enemy. Bardleby was a judge, one of the keepers of the great seal, and otherwise a man of importance. The last reference to Adam le Mareschall is in one of three complaints entered by Alice Burnell of Worcestershire, January 12, I324, in which he is named as one of a large party that trespassed on two manors of hers. Although the complaint does not make the explicit statement, this seems to have been another hunting party.

These facts do not show that Adam le Mareschall was the Adam Davy of the Dreams. They do not connect him in any way with Stratford-at-Bow. In fact the only place with which he is shown to have been connected is Cirencester. The grants of land in Cirencester were all made in the reign of Edward the First as the records show. It is not impossible that he had entered the court shortly before Edward the First's death or shortly after the accession of Edward the Second. $\mathrm{He}$ was a man of importance in I3I4. He was considered reliable surety in I3I6. He may have been a married man and have lived in Stratford, since women were not allowed to live at court unless they held some official position. ${ }^{44}$ Stratford was at that time a village across the river Lea, five miles from St. Paul's. What official position he held at court cannot be determined. If the name Marshal was official, it would indicate that he held office in the Marshalsea, perhaps as knight marshal of the hall.45 Whoever he was and wherever he lived, he was a devoted adherent of his king.

Adam Davy's Dreams is not a Galfridian prophecy, but attention has been given it because it is so obviously propagandist, and because so little has hitherto been known of its author. Among the Galfridian prophecies, with which this study is mainly concerned, the Erceldoune cycle were in all probability propagandist. Murray pointed out that the passage relating to the Battle of Bannockburn predicted an English victory in earlier versions. He thought it not unlikely that this episode in its original form had been written and circulated among the

${ }^{44}$ King Edward II's Household and Wardrobe Ordinances A. D. 1323 ed. F. J. Furnivall, London, 1876 for Chaucer Soc., p. 56.

${ }^{45}$ Supra, 21. 
English troops on the eve of battle in order to refresh their courage and confidence. The poem as it stands is anti-Scottish in sentiment, and may perhaps have been written to browbeat the Scots. If so, episodes irrelevant to the main theme have got into the third fytte.

The Scottish prophecies in Latin, previously discussed, must be considered political propaganda, for they are so strongly patriotic in sentiment and use traditional material in such a manner that one must believe they were written not only to encourage the Scots, but also to intimidate the English. The French-Wife's-Son theme seems to have originated in an attempt to influence opinion in favor of Albany. It was used during the later years of Elizabeth, perhaps, to strengthen the popular conviction that James the Sixth of Scotland was the rightful heir to the throne of England.

The fifteenth century version of The Six Kings ${ }^{46}$ is interesting because of its connection with actual politics. Even the Anglo-French version had prophesied the league of the Lion, the Wolf and the Dragon. But the special application was made by the Percies, Glendower, and Mortimer, who hoped that this part of the prophecy had been accomplished in the Tripartite Convention, ${ }^{47}$ and that the rest of it would be realized in a great victory over Henry the Fourth. Such use of this material was all the more effective because the prophecy was old and venerable, and because it fitted the situation so well.

The Ampulla Prophecy, ${ }^{48}$ ascribed to Becket, has some foundation in real history. Richard the Second while rummaging in the Tower among the relics of his father found a brazen ampulla with a Latin prophecy attached to it. According to the story, Becket during his exile from England spent some time in Sens. One night the Virgin Mary appeared to him in a vision carrying this ampulla filled with oil. She told him that the reigning dynasty of England would become extinct, and that the founder of the new dynasty, who would

${ }^{46}$ This version was paraphrased in the third chapter of this study.

${ }^{47}$ Wylie, Henry the Fourth, vol. 2, p. 379.

${ }^{48}$ Archaeologia, xxf, p. 264, 5, 6. 
wear an eagle on his breast, would be anointed at his coronation with oil from this ampulla. Richard seems to have been greatly affected by the prophecy, for he insisted on a second coronation with oil from the ampulla. But the Archbishop refused, taking the stand that one coronation was enough for any king. Richard was not satisfied, and would not let the relic out of his keeping. He took it with him to Ireland. However, on his return at Chester he gave it into the care of the Archbishop, who used the oil from it to consecrate Henry the Fourth.

Events attending the course of the Puritan Revolution and the overthrow of the monarchy called forth a number of prophecies from both factions. The Cavaliers seem to have revived a prophecy attributed to Grebner concerning Charles the son of Charles, and to have used it for all that could be got from it. Another prophecy of the Northern Lion was applied by the Royalists to the exiled Charles the Second. A third prediction related to a Northern King that should conquer Europe and win a great battle in the Valley of Jehosaphat. Two of these prophetic books, one falsely attributed to Grebner and published in 1648, the other called The Future History of Europe and published in 1650 , seem to have been rather effective weapons. William Lilly, who had been court astrologer but had become a Parliamentarian, felt called upon to refute them. He accordingly published in July, I65I, Monarchy or No Monarchy in England, which was intended to settle the vaticinal dispute.

Monarchy or no Monarchy is very interesting to the student of political prophecies. It was written in all seriousness, and intended by its writer as the final word on a vital and most important topic. In it Lilly analyzes the prophecies which had been interpreted favorably to the Royalists, and shows to his own satisfaction that the interpretations were wrong. He then quotes other prophecies, interprets them, and convinces himself at least that the Fates had determined to allow England no more kings. He follows this vaticinal portion of the book with a treatise on the life of Charles the First, and closes the volume with some pictures in which, according to his own state- 
ment, he endeavored to portray the history of England for several centuries. The main points he considered it necessary to decide, he says in his preface, were whether any more kings should reign in England, and whether the Commonwealth should be permanent.

Lilly directs his attention first to the Pseudo-Grebner Prophecy of I648. The real Paul Grebner had, during a visit to England in 1582, given Queen Elizabeth 'a faire manuscript in Latin, describing therein the future history of Europe, here and there limming in water colors some principal passages.' The Queen gave it to Dr. Nevill, clerk of the closet, who in turn gave it to the Library of Trinity College, Cambridge. In this book Grebner had written a prophecy concerning a Northern King Charles, the son of Charles, who should conquer Spain and greatly weaken the power of the Pope. This Charles was to have a popish wife. The Pseudo-Grebner changed this prophecy to say that a Northern King Charles should reign whose wife should be a popish princess named Marie, but that he should be very unfortunate. His people should choose another commander, an Earl, to rule over them for the space of three years or thereabout. After the Earl should come another commander, a Knight, not of the same family, who should trample all things under his feet. After him the people should choose no one at all. But Charles the Son of Charles with the aid of Denmark, Scotland, Sweden, Holland, and France should overthrow his adversaries, regain the kingdom, and be greater than Charles the Great. Lilly shows that only part of this prophecy written after the event, the choice of the Earl of Essex as Lord General, had been fulfilled, and that the passage relating to the choice of the Knight was untrue.

The Future History of Europe was published in 1650 seemingly to correct the mistakes made in 1648 . The prophecies in it were attributed some to Grebner, some to Baudensis, and one to Merlin Caledonicus. It pretended to foretell the history of Europe from 1650 to 17 Io. In the latter year the beginning of the Fifth Monarchy was predicted to occur. The PseudoGrebner was used to show that the young prince, later Charles the Second, should be a universal conqueror, and that he should 
establish this Fifth Monarchy. Baudensis was quoted as prophesying much the same thing. Lilly refutes this vaticinal argument by showing that the younger Charles, if he fulfilled the prophecy, would have to live to be one hundred and one years old,-a thing not likely to occur. He even goes so far as to say that no King of Scotland ever lived sixty years. Another prophecy of Baudensis was quoted in this work, but Lilly shows that it was grossly misinterpreted, and that it was really unfavorable to the Scottish king.

A prophecy attributed to the Scottish Merlin was also quoted. Lilly translates it in part thus :

"Those times being past, the tayle of the Virgin shall enter the Lyon, and Scorpio shall ascend the backe of Sagitary; the Northern kingdoms shall be wasted by Reapers, the Southern Principalities shall end in dust, and the powers of the Island Monarchies without either Bridle or Souldier shall be harnessed. Cruell wars shall be scattered by winds, and quell'd by a revengeful Hayle; whose beginning were by a staffe, their growth and continuance by Bastards. The Sunne itself shall play on a Timbrel clad with a vermillion coat, and the Moone with dun buskins, shall amble to the faire. Laughest thou, oh King?. . . All these things shall scarce be accomplished, when a Prince of royall stocke shall come forth crowned from the Northerne parts, as to his owne people unexpected, but desired by foreigners; who because he shall beare a rampant Lyon, shall therefore be called a Lyon."

A glorious career ending in a great victory in the Valley of Jehosaphat and the establishment of the Kingdom of Fugitives is predicted for him. Lilly insists that this is a prophecy of the last days, and that it therefore does not apply to Charles.

After riddling the two books that had aroused his anger, Lilly then proceeds to quote from the genuine Grebner and to show that it cannot relate to English affairs. The Charles was meant by Grebner to apply to the king of Sweden. He also quotes other prophecies by Grebner, one by Capestranus, and an astrological prediction on the conjunction of Saturn and Jupiter in July, I623. He then invades the enemy's country and quotes what he considers genuine Scottish prophecies, and interprets them favorably to the Commonwealth. These were taken largely from The Whole Prophecy of Scotland.

After the Scottish prophecies Lilly passes to English proph- 
ecies. He quotes some short predictions, among them the Hempe prophecy. The most significant thing in the whole book, however, is The Prophecy of the White King, attributed to Merlin Ambrose and introduced as part of the argument. According to Lilly's translation it reads :

"When the Lyon of Ryghtfulness is dead, then shall rise a White King in Brittaine, first flying, and after riding, after ligging downe, and in this ligging down, hee shall be lymed, after that hee shall be led. And there shall be shewed whether there be another King. Then shall be gadered togather much folk, and $\mathrm{He}$ shall take helpe for him. And there shall bee Merchandise of Men, as of a Horse or an Ox. There shall bee sought helpe, and there shall none arise, but bed for head. And then shall one gone there the Sun ariseth, another there the Sun gone downe. After this, it shall be said by Britain (King is King) King is no King: after this hee shall raise his head, and he shall betaken him to be a King. Bee many things to done, but wise men reading, .... a and then shall a rang of Gleeds, and ever each hath bereaving, hee shall have it for his owne. And this shall last seven years, loe Ravening and shedding of blood. And Ovens shall be made like Kirkes or churches. After, then shall come through the South with the Sun, on Horse of Tree, the chicken of the Eagle sayling into Brittaine, and arriving anone to the house of the Eagle, hee shall shew fellowship to them beasts. After a year and a half shall be war in Britain. Then shall a sooth be nought worth, and every man shall keepe his thing, and gotten other mens goods. After the White King feeble shall goe towards the West, beclipped about with his folke to the olde place been running water. Then his enemies shall meet him, and March in her place shall be ordained about him, an Hoast in the manner of a shield, shall be formed, then shall they fighten on Ovenfront. After the White King shall fall into a Kirkyard, over a Hall."

This seems to have been quoted from a version belonging to Lady Poston. Immediately after it Lilly quotes one not so full. Its agreement with the second part of the Giraldian Collection is very close. Lilly is scholar enough to give variant readings of some episodes from different versions. He had used at least three. The first version reads suspiciously as if it had been edited for the occasion. But Lilly himself may have been innocent. It is important to notice that the second oldest prophecy was translated and used in $165 \mathrm{I}$ as serious and incontrovertible evidence in a political argument.

It has been said that history made the prophecies by furnishing them with material. In some cases prophecies helped make 
history. It is always difficult to determine how much the complications of a situation or the result of a crisis was due to them. One wisely hesitates without convincing proof to say that any particular event or series of events was caused directly by some prophecy. But one can affirm with safety that prophecies were potent factors in English political affairs, and that their influence seemed constant until the middle of the seventeenth century. They were used seriously during the Commonwealth period. In Wales their influence was very strong. The Welsh cherished their prophecies, and brought them out on the least occasion to hail some expected redeemer of their race. They not only quoted them, but they believed them. An ambitious chief by circulating a suitable and appropriate prophecy could easily gain adherents to his cause. Englishmen on more than one occasion had prophecies to thank for disorders in Wales. ${ }^{49}$ In England predictions, if not the moving cause of uprisings, seditions, and rebellions, certainly helped to complicate the situation by arousing in the rebels false hopes, even certainty of victory. ${ }^{50}$ They were certainly influential in the troublous times leading to the deposition of Richard the Second and in the rebellions during the early years of Henry the Fourth's reign. Percy, Glendower, and Mortimer, doubtless did not believe that Fate and Merlin had decreed the Tripartite Convention among them, but they were undoubtedly quite willing to believe that the prophecy of the Lion, the Dragon, and the Wolf had thereby been fulfilled, and were glad to make the best of what argument and justification the prophecy afforded them.

Particular instances of the direct influence of prophecies are difficult to find. Such direct influence must have been exerted from time to time, as can be judged by the laws which the various monarchs of England passed prohibiting the circula-

${ }^{49}$ Vita Edwardi Secundi auctore Malmesberiensi in Chronicles of the Reigns of Edward $I$ and Edward II, R. S., vol. 2, p. 218; The Political History of England, Hunt and Poole, vol. 3, by T. F. Tout, London, r905, p. 268 .

${ }^{50}$ J. A. Froude, History of England, 12 vols., Longmans, Green, and Co., London, 1898 , vol. 4, p. $45 \mathrm{I}$ for a prophecy used in Kett's Rebellion and its influence. 
tion of prophecies. The first laws that have come to notice in the course of this study were passed in the reign of Henry the Fourth. A law was passed in 1402 against the wandering Welsh minstrels who by their 'divinations and lies were the cause of the insurrection and rebellion in Wales." ${ }^{51}$ A law of I 406 against the Lollards recites among the complaints against the sect that they had published false prophecies which predicted the overthrow of the King, the Princes, and the Lords Temporal and Spiritual. ${ }^{52}$ This law among other things prohibited the use of such false prophecies under penalty of imprisonment without bail and of severe punishment upon conviction.

The use and effectiveness of political prophecies as political propaganda had become so great in the course of the fifteenth and early sixteenth centuries that Henry the Eighth felt it necessary to prohibit them. Accordingly he made it a felony without benefit of clergy 'to declare any false prophecy upon occasion of arms, fields, letters, names, cognizances, or badges. ${ }^{53}$ This law was repealed at the accession of Edward the Sixth in a general act repealing all felonies of the previous reign. It was re-enacted three years later with the penalty for the first offense, one year's imprisonment and the forfeiture of ten pounds, and for the second offense, the forfeiture of all one's goods and imprisonment for life ${ }^{54}$ This was repealed at Mary's accession in a general act similar to the one passed at Edward's accession, and was not re-enacted. Elizabeth, however, had not been on the throne long before she saw the need of a similar law and passed one. This act is very interesting as it rehearses the causes for its passage.

"Forasmuch as sithence the expiration and ending of the statute made in the time of King Edward the Sixth intituled-An Act against fond and fantastic prophecies, divers evil disposed persons, inclined to the stirring and moving of factions, seditions and rebellions within the realm, have been more bold to attempt the like practice in feigning, imagining, inventing and publishing of such fond and fantastical prophecies, as well concerning the

${ }^{51}$ Rotuli Parliamentorum, vol. 3, p. 508.

${ }^{53}$ Supra, vol. 3 , p. 583 f.

${ }^{53}$ Statute 33 Henry VIII, c. XIV.

${ }^{54}$ Statute 3, 4 Edward VI, c. XV. 
Queen's Majesty as divers honourable personages, gentlemen and others of this realm, as was used and practised before the making of the said statute, to the great disquiet, trouble and peril of the Queen's Majesty and of this her realm.

II For remedy whereof, be it ordained and enacted by the authority of this present Parliament,

"That if any person and persons, after the first day of May next coming do advisedly and directly advance, publish and set forth by writing, printing, signing or any other open speech or deed, to any person or persons any fond, fantastical or false prophecy, upon or by occasion of any arms, fields, beasts, badges or such other like things accustomed in arms, cognizances or signets or upon or by reason of any time, year or day, name, bloodshed or war to the intent thereby to make any rebellion, insurrection, dissension, loss of life or other disturbance within this realm or other the Queen's dominions; That then every such person being thereof lawfully convicted according to the due course of the laws of this realm, for every such offense shall suffer imprisonment of his body for the space of one year, without bail of mainprise, and shall forfeit for every such offense the sum of ten pounds."

Further clauses provide that for the second offence the offender shall be imprisoned for life and forfeit all of his property, one half going to the Queen, the other half to the prosecuting witness. The prosecution, however, had to be begun within six months after the offense had been committed.

These laws did not go unviolated. One of the charges against Rhys ap Griffith in his trial for treason was that he had caused to be circulated the prophecy on James, the Red Hand and the Ravens. The Duke of Buckingham seems also to have been accused of relying too much on these fond, fantastical prophecies. The Duke of Norfolk at his trial in $157 \mathrm{I}^{56}$ was accused of keeping by him a prophecy which was interpreted to mean that Elizabeth should lose the throne, that he should marry Mary of Scotland, and that his children by her should inherit the throne. This prophecy is in Latin, and uses the traditional animal symbolism. It runs,

"In exaltatione lunae leo succumbet, et leo cum leone conjungetur, et catuli eorum regnabunt."

At the trial it was translated and interpreted thus:

${ }^{55}$ Statute 5 Elizabeth, c. XV.

${ }^{56}$ Jardine, Criminal Trials, London, 1832, vol. I, p. I75. 
"At the exaltation of the moon (Percy of Northumberland) the lion (Elizabeth) shall be overthrown; then shall the lion (Norfolk) be joined with the lioness (Mary), and their whelps shall have the kingdom."

According to Hickford's deposition read at the trial, this prophecy was originally five or six lines long.

The instances in which prophecies were used as political propaganda and the laws passed by the English kings against the use of them show very forcibly how deeply the genre had penetrated into the life and thoughts of Englishmen. In the course of the study it has been necessary to discuss prophecies which contain little or no animal-symbolism. It is now time to study the genre in the course of its development and to observe the phenomena that marked its rise, flourishing period, and decline. 


\section{CHAPTER FIVE}

\section{The Development and Decline of the Political}

PROPHECY

The origin of the prophecy has now been discussed, and the more important examples of the type have been described at some length. The relation between the prophecies and the political history of England has also been shown. It is now time to consider the genre as a whole, and to observe the phenomena that attended its development and its decline in England.

The prophecy shared with the other types of English literature in the progress from Latin through Anglo-French to expression in some form of vernacular English. It made its first appearance on English soil in Latin, into which it had been translated from the Welsh. Those prophecies which date from the twelfth or early thirteenth century are, with the exception of the Here Prophecy, in Latin. In the thirteenth century, especially towards its close, prophecies are found in Anglo-French. The vernacular prophecy gained strength in the fourteenth century, and thereafter English came to be more and more the usual means of vaticinal expression. The linguistic periods of the prophecies, however, cannot be marked so sharply. The writing of prophecies in Latin continued into the reign of James the First, and Latin prophecies were printed and interpreted as late as $165 \mathrm{I}$. The French forms were more ephemeral, few if any surviving the fifteenth century, for very obvious reasons. Latin was the language of the learned and endured for centuries as such. But when the inhabitants of England ceased to speak French, few of them read French. What was interesting to them in their Anglo-French literature was translated either into Latin or into some English dialect. All three dialects of Middle English are represented. Prophecies in English are found as early as c. I190, as in the case of 
The Here Prophecy, but they are not frequent until after the beginning of the fourteenth century.

From the beginning the prophecies were accompanied by notes and interpretations, or served as bases for elaborate commentaries. The Book of Merlin seems to have had these notes. John of Cornwall made a commentary for his Seven Kings. The Lincoln Cathedral interpretation of Merlin's Prophecies, and the elaborate work by Alanus de Insulis have already been referred to. The Exposition of the Eagle's Prophecy has also been mentioned. This list continues to the very end of the seventeenth century. When no other commentary was provided, marginal or interlinear notes frequently supplied the information needed for an understanding of the prophecies.

In the preceding chapters reference has been made to the re-writing and re-working of older material. Heywood, for instance, in writing his Prophecies of Merlin took material from The Book of Merlin and The Six Kings, and combined it with material gathered from various sources or got from his own invention. ${ }^{1}$ The Cock-in-the-North motive lasted long. Arising perhaps from a couplet in Bridlington, it found its way into various English and Scottish poems of the fifteenth and sixteenth centuries, and re-written as a 'Prince out of the North' was used in the Jacobite Rebellions in the eighteenth century. The Last-King-of-Rome story, relating to the successful crusade of an English king and his death in the Holy Land, was used in prophecies from the thirteenth century on, and was applied to Edward the Second, Edward the Third, Henry the Fourth, Henry the Fifth, Henry the Eighth, Charles the Second, and the Stuart Pretenders.

No particular literary form ever came to be recognized as the only proper medium of vaticinal expression. The only quality the prophecies had in common was obscurity. Latin prose was used for The Book of Merlin, The Giraldian Collection, The

${ }^{1}$ Material from The Six Kings is used beginning with Edward the First, but Richard the Second is called a Kid instead of the Ass of Wickedness, and Henry the Fourth a Fox instead of the Accursed Mole. The prophecy made by Henry the Fifth that Windsor should lose what Monmouth should gain is worked into the account of his reign. After the time of Henry the Fifth Heywood makes the best of what material he finds at his hand. 
Exposition of the Eagle's Prophecy, and numerous short pieces. The Latin version of The Six Kings is in prose as is Asinus Coronatus. Prose is also used in the Anglo-French version of The Six Kings. John of Cornwall, however, chose to put his version of Merlin's prophecies into metrical form, using as his medium of expression the Latin hexameter. Bridlington, like many short vaticinal pieces in Latin, was written in leonine lines. Vernacular prophecies are in both prose and verse, those in verse using various metrical forms. Becket may serve as an example of those written in alliterative long lines. The Six Kings is written in riming couplets which, however, cannot be scanned easily. The prevailing line seems to be iambic and octosyllabic, but the first unstressed syllable and the unstressed syllable occurring after a strong pause are sometimes omitted. Adam Davy's Dreams is also written in riming couplets in what seems to be tumbling-measures. The ballad stanza was very popular, especially after the close of the fourteenth century. One of the earliest analogs of Erceldoune is the Northumbrian ballad which has already been described. Erceldoune and its later versions, The Cock in the North and its revisions, and several poems in The Whole Prophecy are written in the ballad stanza. The Prophecy of the Fishes is written in an intricate stanzaic form which combines rime and alliteration, but the position of the riming lines varies in each stanza. A closer study of the prophecies would perhaps reveal greater metrical variety, but the cases cited are sufficient to show that this variety exists.

One of the most noticeable phenomena in the history of the Galfridian prophecy is the change in the symbols. Those in The Book of Merlin were arbitrary. If one could trace them to their Welsh originals he might find that they were petrified metaphors used in much the same way as the Welsh epithets which were studied in the second chapter. However, from the point of view of English literary history the animal names are purely arbitrary and mean nothing. Some of these arbitrary symbols were remembered and applied to the same individuals for several generations. They then became conventional. At times the symbols fit the character of the man. Henry the 
Third, who was a pious and good man though a weak king, is called the Lamb. Edward the Second was uniformly referred to as the Goat. Those who called Richard the Second the Ass of Wickedness were perhaps his enemies, and those who called him the Lamb his friends. This, however, is pure supposition and must not be pushed too far. Sextus, though not an animal name, became a purely conventional symbol. The 'Lynx seeing through all things,' applied for a time to John, survived to be used as a conventional, traditional, and arbitrary symbol in The Exposition of the Eagle's Prophecy. The use of the Crab for the King of Scotland in this same piece antedates Bridlington, and is another instance of the arbitrary symbol that became conventional. These conventional symbols lasted until I65I. The Son of the Eagle was then interpreted as the Prince who later became Charles the Second.

Not infrequently a symbol was used with some special significance where it first occurred, but later lost its significance and became conventionalized. Such seems to be the origin of The Cock in the North. This was perhaps only a translated pun used in Bridlington for the King of France and applied to the Black Prince. When this Prince failed to become King of France, the symbol was conventionalized and made traditional. Even after the symbol itself was dropped the expectation of a Prince from the North remained. The history of the Leaffrom-the-left-side-of-Bruce and the French-Wife's-Son, both of which were later combined, is much the same.

The obscurity of the prophecies was due in large measure to uncertainty as to whom the symbols represented. A key was necessary for the understanding and explanation of them. Such obscurity defeated their purpose to some extent. The difficulty in recognizing the man behind his vaticinal mask was too great. The situation, however, was relieved by the rise of heraldry ${ }^{2}$ which afforded for every prominent man a symbol that was readily intelligible. The earliest prophecy containing heraldic symbols that has been found in the course of this

${ }^{2}$ Heraldry was practised in England as early as the reign of Richard the First; how much earlier is uncertain. 
study dates perhaps from the middle of the thirteenth century. It is a prophecy attributed to Merlin in The History of Fulk Fitzwarine. $^{3}$ Merlin is here said to have prophesied that a Wolf would come out of the White-Land and overcome the Leopard. By the Wolf was meant Fulk, who bore on his shield a wolf's head with four teeth exposed; by the Leopard King John, who bore 'the leopards of beaten gold.' Earlier in the History it had been said that the Wolf would first drive out the Boar. This was perhaps Morris FitzRoger, who was defeated by the hero and who is described earlier in the book as bearing two boars of gold on a shield of green. Few examples of heraldic symbols are found in the thirteenth century. After the beginning of the fourteenth they occur more frequently. The Latin prophecy beginning Anglia transmittet Leopardum is an example. In it the Leopard which appeared on the shield of the King of England was used for the King himself, and the Lily by a similar figure of speech for the King of France. In Becket the imperial Eagle was used for the Emperor himself. The Lily came to be used as a conventional symbol for France or her King, but the kings of England were more often known by their individual crests or badges. Richard the Third, for instance, was referred to as the White Boar, which was his special cognizance.

Prophecies containing symbols derived from heraldry only are rare. The Merlin prophecies in The History of Fulk Fitzwarine are good examples. Another seems to be a sixteenth century collection called Metrical Prophecies.4 A Bear, a Dragon, an Eagle, a Falcon, a White Horse, the Cock of the North, a Wolf, and a Water-Bogie appear in the course of the narrative. Marginal explanations are given for all but the last three. The Cock of the North may stand for Henry the Eighth, who took the Cock as his crest. The other two may well be heraldic, since all but the Cock plainly are. A superscription to The Metrical Prophecies shows that the copy was

\footnotetext{
${ }^{3}$ The History of Fulk Fitzwarine, ed. T. Wright, London, 1855. This is an Anglo-French prose romance that dates from the early fourteenth century. Wright and Ward (Cat. I, 50r) think it originally metrical and composed c. I254. 'The prophecy is in verse.
}

'Reliquiae Antiquae, II, I2-I3. 
made on July 19, 1552. A short introduction shows that the prophecy as it there occurs was meant for the same year. It must be older, for the ruler of the country is spoken of as a king who should beget on a poor maiden a flower 'that schalle warne alle kinges as he leste every owere.'

As a rule both arbitrary and heraldic symbols are found in the same prophecy. The more important characters in The Six Kings are given arbitrary names, but Gaveston is called the Eagle of Cornwall, for he bore eagles on his shield. Both kinds of symbols are used in Bridlington. Edward the Third is the Bull, Prince Edward the Cock, the King of Scotland the Crab, not to mention others. But various other animal names that occur in the prophecy are explained in the notes as representing nobles who bore such animal figures in their coats of arms. Brandl attempts to interpret some of the symbols in Erceldoune as heraldic emblems, such as the Heron and the Bastard, regarding the Falcon, the Raven, the Tercelets, and the Crow as arbitrary names. The same is true of his interpretation of The Cock in the North. The Bull and the Moon are taken to stand for the Earls of Westmoreland and Northumberland respectively. An attempt to explain the Cock as heraldic presents a difficulty which became characteristic of this particular kind of symbol. The trouble with animal names taken arbitrarily was that the mask hid too well the person it was meant to disguise. With heraldic symbols the difficulty lay, when heraldry was far advanced, in determining which of perhaps a hundred cocks or a hundred lions was meant. ${ }^{5}$

Certain of the arbitrary symbols were conventionalized and made traditional. The same thing occurred in the case of certain heraldic symbols. The Lion was used for several generations of Scottish Kings. When it was found necessary to distinguish it from other lions, it was called the Red Lion, as in the Rymour Prophecy in The Whole Prophecy. Similarly, though less frequently, the Leopard was used for the English

- The use of heraldic symbols despite the prohibition of Henry the Eighth, Edward the Sixth, and Elizabeth flourished, and continued into the nineteenth century among the Scottish Highlanders. Prophecies of a Highland Seer, C. F. Cumming, in Eclectic, vol. 105, p. 696. 
Kings, perhaps only for the first three Edwards. The Dragon, derived from the ensign of Cadwalader, could represent any Welsh Prince. In the episode of the Mole in The Six Kings it was interpreted as applying to Glendower who, as a champion of the Welsh, had adopted the Dragon for his standard. The Lily represented any King of France. In like manner certain symbols recur for different leaders in different generations of the great noble families. The Moon (luna) was used for the leader of the Percies in the fifteenth century Asinus Coronatus. It was used for the leader of the same family in the prophecy quoted against the Duke of Norfolk at his trial in 1572 . The Bear, originally the crest of the Beauchamp Earls of Warwick, was used in the fifteenth century for Richard Neville, who became Earl of Warwick by marrying the Beauchamp heiress, and in The Metrical Prophecies for Dudley, Earl of Warwick, who had no ancestral right to the Bear as a crest. Because of this use of conventionalized symbols it is frequently necessary to have some idea of the date of a prophecy before one can interpret it properly.

Attention has thus far been given only to those prophecies which use the Galfridian method of animal symbolism. It would be a mistake, however, to suppose that English political vaticinations were written in no other method. Several prophecies relating to English affairs may be called Sibyllic according to the conventional initial-reference of this type of prophecy. This difference exists between the English and the Continental Sibyllic prophecies. On the continent the prophecy proceeded as any historical narrative, giving some attention to details but with initials used for names of persons. But in England the prophecies written according to the Sibyllic method were short, concise and compact. For instance, one two lines long, which was attributed to Becket, runs thus:

$H$. Patre submarcet post $R$. reget J. qui relicto ${ }^{\circ}$

E. post H. rex fit. E. post E., postea mira.

${ }^{6}$ Ward, loc. cit., I, 3 I 4 .

Cf. Upan's Prophecy (Lilly, loc. cit., 36)

To tell the truth, many one would wonder

Charing Crosse shall be broken asunder 
In some cases the initials were combined to form words. An excellent example of this kind is the so-called Hempe Prophecy, quoted by Bacon in his essay Of Prophecies. It seems to have been very popular, for it occurs frequently with only slight variations. In one version it reads,

\section{"After Hempe is sowen and growen Kings of England shall be none."}

H. stood for Henry the Eighth, E. for Edward the Sixth, M. and P. for Mary and Philip of Spain, and the last E. for Elizabeth.

An interesting combination of the Sibyllic and the Galfridian methods is found in the poem, Six Letters to Save Merry England. ${ }^{8}$ The narrator while walking in Cheapside saw a lady embroidering a garment with twelve letters which she said were to save merry England. The letters were five R's, two E's, W, F, M, Y, S. Three of the R's stood for three men named Richard, one for the Rose (which the editor interprets as the White Rose of York), and one for the Ragged Staff (the badge of the Earl of Warwick). One E. stood for Edward, the other for the Eagle (the badge of the Earl of Salisbury). M. represented the Earl of March, W. the Earl of Warwick, S. the Earl of Salisbury, and F. the Fetterlock (the badge of Edward the Fourth). All these, said the lady, work together for King Edward's weal and the destruction of treason. The use of initials makes the prophecy Sibyllic. But since four of the letters stand for heraldic badges, they are vaticinal symbols and make the prophecy in part Galfridian.

One finds, furthermore, curious prophecies which do not fulfill the requirements of either the Galfridian or the Sibyllic

P. shall preach, R. shall reach, S. shall stand stiff

P. presbytery, R. Roundhead, S. souldier.

and also (Lilly, loc. cit., 57)

Accursed in E. Norman's heire,

England's crown shall never wear.

E. Elizabeth.

${ }^{7}$ Harington, Tract on Suc., p. I 7.

${ }^{8}$ F. J. Furnivall, Political, Religious, and Love Poems, E. E. T. S., O. S. I5, p. I f. 
type. $^{9}$ Two very interesting prophecies, which are worked into one poem in a manuscript among the state papers of Henry the Eighth, ${ }^{10}$ make use of dicing terms. The poem runs as follows;

"Then quater shall a-Ryse

and set uppe sise,

Then England shal bee in paradyse.

When trey and quater ys myswente,

Then all England shall bee shente,

Then shall ye have a newe parliament;

Then cinq (sise?) shall a-Ryse, and cinq shall undre,

A ded man shall a-Ryse, And that shal bee greate wondre;

He that (is) dedde and buryed in sight shall a-Ryse agayn and lyve in land, In comforting of a yonge knyght

That Fortune hath chosyn to be his feer. ${ }^{11}$

"Whan sise ys the best caste of the dyesce

And oon beryth uppe sise

Then England ys paradysce.

But when cinq and quater bee set a-syde,

The worde of sise shall sprynge full wyde;

But when deuce put owte trey, Then ys all shente,

for than we shall have a newe parliament.

Yet sise shall uppe, and ace shall undre;

When dedde men Ryse, It shal bee greate wonder.

The Lyon, the Redrose, and the flower de Luce,

The Locke shall undo deuse,

Yet sise shall bere the price,

And ace shall help therto."12

${ }^{9}$ In the nineteenth century at the time of the Franco-Prussian War many numerical prophecies were published. (Cf. Notes and Queries, series 4, vol. I2.) In these, certain combinations of certain numbers gave the date of a supposedly eventful year. It is needless to say that they are unintelligible without a key.

${ }^{10} \mathrm{~F}$. J. Furnivall, Ballads from $M$ s., p. $318 \mathrm{f}$.

${ }^{11}$ Cf. two lines from The Prophesie of Marlyng in The Whole Prophecy:

Syce shall up, and sink shall onder.

the ded shall rise, and worke great wonder.

12 The date 1450 is written at the close of another version in Ms. Harleian 7332. The Sink and Fire Prophecy seems to be a corrupt version of this. "The synke \& the fyre shal be guylgully bought. And when the fyre standythe under the synke! then stands England without a rightous kyng but the vi shal shall (sic) upp \& the synk shall under

When did men ryse there wylbe moche wonder"

(Notes and Queries, series 4, vol. 12, p. 223 : cf. The Best Cast of the Dice, Notes and Queries, loc. cit., p. 443.) 
The remaining lines of the prophecy contain nothing interesting. The typical animal-symbolism creeps into it sufficiently to make the prophecy Galfridian.

Just as the kind of symbols changed, so the manner of carrying on the narrative changed. In The Book of Merlin animal names were usually employed but not exclusively. Sometimes other symbols were used, as in the case of the tree with three branches, and in the case of the three fountains of Winchester. But the whole piece reads very much like a beasttale. The material is condensed, and the episodes follow each other compactly in rapid succession. Few episodes that are not meant to express pure action are introduced. ${ }^{13}$ The same is true of The Giraldian Collection, and, to a less extent, of The Seven Kings. The Cock in the North and The Prophecy of the Fishes are both written in the Galfridian method. As late as 1572 this method was preserved in its purity in the prophecy used against the Duke of Norfolk.

On the other hand, prophecies are found which are straightforward narrative without symbols. Prophetic obscurity is obtained by slight allusions more or less indefinite to the events and conditions which the given piece attempts to portray. The Here Prophecy, though brief, is an excellent and early example, for in it only a suggestion of the situation is given. The Grebner and the Pseudo-Grebner prophecies are both straightforward narratives with no attempt at disguise. The obscurity lies in faint allusion and slight suggestion. The events predicted, such as wars between countries and the fall of great cities, are plain and unmistakable enough.

Some prophecies combine the symbolical and direct methods. The vaticinal part of Becket is imbedded in pure narrative of travel. The battles of Caen and Mountjoy and the burning of Abbeville are foretold without any attempt at vaticinal disguise. In Bridlington the symbolical parts are only a small portion of the whole. The internal affairs of the realm, the taxes, the plague, the various miseries and sufferings of the

${ }^{13}$ An exception must be made in the case of the episode, "The half shall be round," which relates to the coinage of Henry the First, and similar episodes. 
people, the misconduct of the king, all are told without recourse to symbols. In Erceldoune many elements are fused. The first fytte with its romance motive is irrelevant to this study. The second fytte is largely simple and direct narrative. Even in the third fytte the symbols are few. In fact, one coming to Erceldoune without a fair knowledge of the genre might have some justification for not considering it an example of the type. Many of the prophecies quoted by Lilly contain only one or two symbols while the rest is direct statement. It would be a mistake, however, to suppose that the type in its purity did not survive to the end of the period.

Other pieces are to be found which avoid prophetic symbols altogether or use them sparingly, and which gain the requisite amount of uncertainty by employing figurative, metaphorical, and highly colored or bombastic language. The old Vision of Edward the Confessor, described in the first chapter of this book, is an allegory though expressed somewhat simply. The meaning is rather hard to comprehend, and the application is difficult to make. The prophecy attributed by Lilly to the Scottish Merlin and quoted in the preceding chapter is written in vivid, and very figurative language. These are not to be regarded as purely literary efforts with no reference at all to political history. The highly ornate and rhetorical Latin style of Bridlington is analogous. In fact, Bridlington except for the occasional animal-symbolism would be an excellent example of this rhetorical class.

There are also prophecies which have no rhetorical elaboration and in which the events are not described in direct style, and which have no symbols. The effect is sometimes gained by the use of paradox and by narrating as fact things which seem impossible. The Harleian prophecy of Erceldoune, quoted in full in the third chapter, is such. The wedding of lads with ladies was something supposedly impossible because of the difference in social rank. The ending of the war whenever the hare should kittle on the hearth-stone was something of a paradox. It must be said that few examples of these paradoxical prophecies have been found in the course of this study. This class lent itself to parody and burlesque as will be shown later. 
Prophetic pictures constitute another very interesting kind of prophecies. The vaticinal tapestry said by Barbour to have been made by Saint Margaret has been mentioned in the review of Scottish prophecies. The earliest pictures of this kind that have come to the notice of the present writer are The Oracles of Leo the Philosopher, ${ }^{14}$ which date from the eleventh century and relate to Byzantine affairs. Pictures of this kind became very popular on the continent during the fifteenth and sixteenth centuries, and series of them were published by men of authority as philosophers. They were known in England as early as 1586, when the Earl of Northampton ${ }^{15}$ speaks of them as if they were quite common. William Lilly devoted the last twenty pages of his Monarchy or no Monarchy to nineteen pictures in which he attempted to prefigure the history of England for several hundred years beyond his own time. These pictures were not without imitators.

The first of Lilly's pictures are concerned with the Puritan Rebellion. The second of the series, for instance, by the representation of two prelates tumbling from their pulpits shows the overthrow of the Established Church. The sixth with its four starving and dying cows obviously was meant to show a famine. A plague is evidently predicted in the eighth which shows several shrouded bodies, a pest-house, and two men digging graves. The Fire of London was anticipated by the thirteenth which pictures a city in flames. In several pictures there seems evidence that Lilly knew the episode in The Six Kings relating to the Mole, the Wolf, the Dragon, and the Lion. In the tenth picture the Mole is seen approaching the crown. In the twelfth the Mole, the Dragon, and the Lion figure. Rivers of blood, apparently shed in the strife between the Mole and the Dragon, are seen in the fourteenth. In the fifteenth the Wolf and the Lion are shown embracing each other most joyously, while the Mole seems to be in great distress. The seventeenth picture shows the Lion, the Wolf, and the Dragon ruling the land, and the Mole and his family dead.

\footnotetext{
${ }^{14} \mathrm{~K}$. Krumbacher, Geschichte d. byzantinischen Literatur. München, $I 89 x$, p., 249, 402. For the pictures see Migne, Pat. Graecae, 107, Ir30, II 5 I.

${ }^{15}$ Earl of Northampton, Defensative, c. CXXIII.
} 
In $165 \mathrm{I}$ the Galfridian prophecy was plainly decadent. Those examples which represented the type in its vigor and purity were usually survivals from the earlier centuries. One cannot deny, however, that vaticinal pieces, such as The Northern Lion, quoted by Lilly, are to be found with Galfridian elements, but in comparison with the original form as exemplified in The Book of Merlin they seem weak and at times almost puerile. ${ }^{16}$ No long sustained work like The Book of Merlin, Bridlington, Erceldoune, or The Six Kings was produced. The most important production so far as length is concerned is The Whole Prophecy, which is but a collection of older material. The Sibyllic prophecy attributed to Becket, The Hempe Prophecy, The Mars Prophecy, ${ }^{17}$ and similar pieces are certainly emasculated specimens. Prophecies too frequently degenerated into merely local predictions, such as that quoted by Lincoln in Sir Thomas More ${ }^{18}$ 'that Lincoln should be hanged for London's sake.' Many similar things can be

${ }^{16} \mathrm{Cf}$. the exquisite absurdity of William's Prophecy (Lilly, 69).

Christ went to court some seven years since and there he left his Asse.

The Courtiers kickt him out of doores, because there was no grasse.

The Beast went mourning ever since, and thus I heard him Braye;

Although there was no grasse at court, they might have given me Haye.

But sixteen hundred fourty one

Who ere shall live that day

Nothing shall see within that court,

But only grasse and Hay.

And then you may be sure,

The yeare that next ensues,

One silly Asse shall be more worth

Than all the Horse ith' Mewes.

$\begin{array}{ccllllll}{ }^{17} \text { Mars } & & \text { Puer } & \text { Alecto } & \text { Virgo } & \text { Vulpes } & \text { Leo } & \text { Nullus. } \\ \text { Henry } & 8 & \text { Edward 6 } & \text { Mary } & \text { Elizabeth James I } & \text { Charles I }\end{array}$

(Lilly, 56)

${ }^{18}$ Sir Thomas More, Act III, Sc. I, line 47 ed. Tucker Brooke, The Shakespeare Apocrypha, Oxford, 1908. 
found in Nixon's Cheshire Prophecies. ${ }^{19}$ For the animalsymbolism, which was impressive in a way, vulgar prodigies were used. Instead of a glorious Dragon one was to expect a 'Miller with two thumbs.' The prodigies are usually characteristic of local prophecies.

One reason, perhaps, for this decadence was the fact that another outlet for vaticinal inclinations was found in the growing popularity of astrology. Astrological predictions and prognostications appear in England early in the sixteenth century. ${ }^{20}$ A Prognostication was printed in black letter for Richard Banckes in 1523. An Almanac and Prognostication for 1530 by Gaspar Laet the Younger was printed in English at 'Antwerp in 1530. Another for the following year by the same man was printed in London. Thereafter almanacs, prognostications, astrological predictions, and books on astrology become very frequent. Professional astrologers such as Arise Evans, John Dee, Richard and John Harvey, Dr. Simon Forman, Sir George Wharton, H. Johnsen, John Booker, John Case, Coley, Lilly, and Partridge rose to positions of power and influence in the nation. ${ }^{21}$

The nature of these astrological predictions may be inferred from Grebner's prophecy on the conjunction of Saturn and Jupiter, July, $1623:^{22}$

“I. Divers sinister events shall seeme to conspire together for the crossing of a great Prince, who by opposing the common People, shall in the end drive them to Sedition.

"2. The Conjunction of Jupiter and Saturn in the House Celestial, called that of Death, doth portend that some Prince shall be detained prisoner, to the great disadvantage of his affaires of Estate.

"3. Upon the first quarter of the Moon, which shall be the 27. of February is foretold, That some King or Prince shall undertake a voyage of great consequence without certainty of return, which at the best shall both be later than expectation, and after the enduring of many miseries.

${ }^{19}$ Notes and Queries, series 4, vol. 3, p. 609; The Palatine Anthology, London, r850, p. I6r f.

${ }^{20}$ Englishmen had known something of astrology at a much earlier date. Robert of Torigny, Chronicle, R. S., London I889, p. 283, quotes an astrological prediction of II 79 .

${ }^{21}$ See these names in Dictionary of National Biography.

${ }^{23}$ Lilly, $27 \mathrm{f}$. 
" 4. He which shall stand on the top of Fortune's wheel, let him look warily to his feet for fear of slipping; because so great a fall is threatened him, as shall procure his utter ruine; which shall astonish those who have climbed up into the seats of honor unworthily.

" 5. A monarch that hath betrusted his affaires of great Consequence to the direction of one, who was no way capable of so weighty a charge, shall be sensible of the great fault he hath committed, whereof he shall too late repent.

"6. The stirrers and Incendiaries of Sedition shall make residence in the Houses of Kings and Princes.

“ 7 . War deferred through want of money.

" 8. The Land and Town Geminist shall bewaile the want of her Sun.

"9. Here shall be great levying of Souldiers for the execution of some stratagem, but all shall turn to nothing; for the sudden departure of a great Personage shall cause much Murmuring and Discontent.

" Io. Men disguised shall desire that their outward semblance may make shew of that which they are not, and shall be Authors of many particular combats in the Land Geminist."

The Prognosticall Judgement of the Great Conjunction which shall happen the 28the of April, by Robert Tanner, entered in the Stationers' Register under date of March Ir, I 583 , seems to have been much the same kind of thing. The conjunction referred to was doubtless one between Saturn and Jupiter. Another book on the conjunction of these planets was entered April I2 of the same year.

The annual prognostications popular in the seventeenth century began very early, and were at first mere proverbial weather predictions. A set of prognostications in Latin, dating from the first half of the eleventh century, relate to the signs of the weather as shown by the sun and moon. ${ }^{23}$ In another set the weather is foretold from its state on certain days of the year, one of which is the second of February. ${ }^{24}$ In still another the state of the weather during the different seasons is foretold according to the day of the week with which the year begins. For instance, if the first day of the year is Sunday, the Winter will be mild, Spring windy, Summer and Autumn dry. But if the first day of the year is Saturday, it will be a bad year for everybody. ${ }^{25}$ Such seems to have been the simplest

${ }^{23}$ Rel. Antiq., I, 15.

${ }^{24}$ Supra, 93.

${ }^{25}$ Ms. Cotton. Vesp. D., I4. 
form of the annual prognostication, a general and proverbial statement of weather signs. This came in time to result in prophecies that attempted to predict the events of the year for which they were cast. ${ }^{26}$ These events included perhaps political affairs and the phenomena of the weather. The combination of this annual prognostication with the astrological prediction gave the Elizabethan almanac, from which the almanac of the present day is directly and legitimately descended.

Unfortunately, the present writer has not been able to examine the Elizabethan almanacs that are extant. It is possible, however, to judge of the contents of the average specimen from the descriptions given in entries in the Stationers' Register, and from burlesques on the form. Gayle's Almanac and Prognostication, licensed in 1566 and again in 1567 , contained information concerning surgery. An Almanac for the Months was licensed in 1563 by Owen Roger. Joachim Hewbright's Almanac and Prognostication, licensed in 1566 , was published 'with the breffe and profytable Rule for marynours to know the ebbes floodes Sowndynges landynges Markes and Dangers.' An Almanac with the Names of the Kynges, licensed in 1566 , evidently contained bits of historical information. Dernyll's Merry Prognostication for 1567 may have been a joke-book. The Raven's Almanac, licensed to Laurence Lyle July 7,1608 , contained predictions of famines, plagues, and civil wars.

It is possible to reconstruct for present purposes the typical almanac from Dekker's Raven's Almanac, which is evidently a burlesque of the last book mentioned in the preceding para-

${ }^{26}$ Prophecies of the regular Galfridian type were written for certain years. The Tolle caput Martis is an excellent example. Its earliest form dates from the late thirteenth century at the time of the expected birth of the prince who later became Edward the Second. In the Exposition of the Eagle's Prophecy definite dates are set for some of the happenings predicted therein. In the Latin Prophecies against Edward the Third I38I is given as the exact date for the extinction of his dynasty. Several prophecies each for a special year are contained in Ms. Cotton. Vesp. E. vii. 
graph. ${ }^{27}$ If the contents of the book, burlesque as it is, furnish a guide, one would infer that the usual almanac of the time contained an epistle to the reader, the astrological figure of the Signs of the Zodiac, and a dissertation on the influence exerted by the signs on the different parts of the body, predictions for the twelve months, each introduced by a quatrain of dietary advice, a list of the festivals and Saints' Days in each month, the time of sunrise and sunset for each day, predictions for the four seasons and the names of diseases peculiar to each season with the appropriate remedies, the distinctive characteristics of people born in each season, and perhaps short illustrative pieces of narrative.

The reasons for the decadence of the type are not far to seek. The stringent laws passed by the Tudors, and continued by their successors, against the use of prophecies had a strong and lasting effect. What prophecies survived this judicial ordeal had few Galfridian elements. The growing freedom from superstition had its influence as well on the belief in all kinds of prophecies. People were likely to be more skeptical and to doubt the inspiration of those who set themselves up, or were set up by others, as prophets. Merlin's reputation had been failing not only in England but also in the rest of Europe since a decree of the Council of Trent had been passed against him, and since his prophecies has been listed in the Index Expurgatorius. Men of intellect ceased to believe the prophecies, however much the vulgar may have cherished them. Bacon in England and Montaigne in France each devoted an essay to preaching against prophecies and prognostications.

Bacon's essay, Of Prophecies, the thirty-fifth in the collected series, is rather short, for he treats the subject in a very desultory way. He says in the beginning:

\footnotetext{
${ }^{27}$ Dekker's title-page reads: The Raven's Almanac Foretelling of a Plague, Famine and Civill Warre. That shall happen this present yeare 1609, not only within this Kingdome of Great Britaine, but also in France, Germany, Spaine, and other parts of Christendome. With certaine Remedies, Rules and Receipts, how to prevent, or at least to abate the edge of these universal calamities. London. Printed by F. A. for Thomas Archer, and are to be solde at his Shop in the Popeshead-Pallace nere the Royall Exchange. I609.
} 
"I mean not to speak of divine prophecies: nor of heathen oracles: nor of natural predictions: but only of prophecies that have been of certain memory, and from hidden causes."

$\mathrm{He}$ calls to mind several classical prophecies and dreams, such as the prophecy of Caesar's Ghost to Brutus regarding Philippi. He then speaks of prophecies in England and quotes Hempe. He also quotes another which antedated the Armada but was supposed to have predicted it. In closing he says:

"My judgment is, that they ought all to be despised; and ought to serve but for winter talk by the fireside. Though when I say despised, I mean it as for belief; for otherwise, the spreading. and publishing of them is in no sort to be despised. For they have done much mischief; and I see many severe laws made to suppress them. That that hath given them grace, and some credit, consisteth in three things. First, that men mark when they hit, and never mark when they miss; as they do generally of dreams. The second is, that probable conjectures, or obscure traditions, many times turn themselves into prophecies; whilst the nature of man, which coveteth divination, thinks it no peril to foretell that which indeed they do but collect. ... The third and last (which is the great one) is, that almost all of them, being infinite in number, have been impostures, and by idle and crafty brains were combined and feigned after the event passed."

The Earl of Northampton had indeed gone farther than Bacon in his opposition to prophecies. In the Defensative ${ }^{28}$ he

${ }^{28}$ Northampton wrote the book while he was in retirement at St. Alban's in ${ }^{5} 53$ and dedicated it to Sir Francis Walsingham. (See Dict. Nat. Biog., vol. 28, p. 29, ed. 1892 .) The author incurred the suspicion of treason and heresy in the book and was sent to the Fleet in 1583 . In the second edition the Defensative contains an Epistle Dedicatory, a letter To the Reader, and thirty-six chapters of varying length. The whole makes a book of three hundred and thirty pages. Who was responsible for the augmentation and division into chapters of this edition has not been learned. The title page of this second edition is a fair indication of its contents and its writer's attitude. It reads: A Defensative against the poyson of supposed Prophecies. Not hitherto confuted by the Pen of any Man, which being grounded, either upon the warrant and Authority of Old Painted Bookes, Expositions of Dreames, Oracles, Revelations, Invocations of damned Spirits, Judicials of Astrologie, or any other kinde of pretended knowledge whatsoever, De futuris contingentibus; have been causes of great disorder in the Commonwealth, especially among the simple and unlearned people. Very needful to be published, considering the great offence which grew by most palpable and grosse errors in Astrologie. Written by Henry Howard, late Earle of 
takes the position that prophecies are 'but the scum of pride and the dregs of ignorance,' that prophecies cannot alter God's law, and that God himself through the instrumentality of a chosen few reveals what he wishes to have known. The Earl rejects every prophecy that has no Biblical authority, and accepts those in the Bible in a spirit that smacks somewhat of a necessity to avoid a charge of infidelity. He rejects ' whatsoever kind of prophecy which presumes to divine or aim at any future accident whose means are not already set on work; but merely to come without the knowledge of the next most natural and most proper causes.' He first endeavors to determine the causes that prompt men to pry into the future. $\mathrm{He}$ finds them to be: first, 'scruples of suspect and jealousy implanted by Satan'; secondly, diffidence and deep mistrust in God; thirdly, 'vain and rash credulity,' which he calls the nurse of error; fourthly, 'curiosity to search and hunt for deeper knowledge, after future causes and affairs of the Commonwealth, than God pleases to make known by ordinary means.' After showing how unworthy are the things which give rise to desire for divination he proceeds to refute some arguments that had been advanced in favor of prophecies. The fact that so many people would not have believed in prophecies without good grounds, he insists is no proof at all, saying that human nature was always prone to please itself with shadows and conceits, and that truth is justified by weight, not by number. To those that heed prophecies because they make men more wary in abstaining from offence (an argument advanced in the introduction to Bridlington), he says that a man may not do evil in the hope of good results, that experience shows more people puffed up with pride than reclaimed from the rage of sin, and that warnings of our frail and slippery state are not so rare and dainty that one need repair to the closets of false oracles. The author then discusses all the methods of divination and proves by the precept of ancient philosophers and of

Northampton, Lord Privy Seale, etc. Now newly revised and divided into divers severall Heads and Chapters. Printed by John Charlewood, servant to the right honorable Philip Earle of Arundel, 1583. And reprinted by W. Jaggard, and to be sold by Matthew Lownes in Pauls churchyard, at the signe of the Bishopshead, 1620 . 
the Church Fathers that these methods are really nonsense. He denies inspiration for secular prophecies but affirms it for the religious prophecies. The book is disappointing in that it bears so little on English material, but deals largely with examples taken from Biblical and Classical history. ${ }^{29}$

Opposition to belief in prophecies was shown not only by adverse legislation and long arguments, but also by parodies, satires, and burlesques on the type. This method of attack was begun as early as the third quarter of the fourteenth century. It is used twice in the B- and C-texts of Piers the Plowman. The first example occurs in the third passus:

"Non levabit gens contra gentem gladium. etc.

And er bis fortune falle fynde men shal be worste, By six sonnes and a schippe and half a shef of arwes;

And be myddel of a mone ${ }^{-}$shal make be jewes to torne, And saracenes for bat sizte 'shulle synge gloria in excelsis $\mathcal{E}$,

For Makomet \& Mede $\cdot$ myshappe shal bat tyme." (Lines 321-327)

The second occurs at the end of the sixth passus:

"Ac I warne zow, werkemen wynneth while ze mowe,

For hunger hiderward hastest hym faste,

He shal awake with water wastours to chaste.

Ar five zere be fulfilled such famyn shal aryse,

Thorowgh flodes and bourgh foule wederes fruits shul faille

And so sayde saturne ${ }^{\circ}$ and sent zow to warne;

When ze se be sonne amys ${ }^{\circ}$ and two monkes hedes,

And a Mayde have be maistrie ${ }^{\cdot}$ and multiplie bi eight,

banne shal deth withdrawe ${ }^{\circ}$ and derthe be justice,

And dawe be dyker deye for hunger,

But if god of his goodness'graunt us a trewe." (Lines 322-332)

These passages sound very much as if they were deliberate parodies of actual prophecies then popular.

${ }^{29}$ Compare John Spencer, A Discourse Concerning Vulgar Prophecies, London, I665. Spencer accepts the inspiration of the Biblical prophecies but denies it for the others. He says that secular prophecies have a bad influence on Church and State and that belief in them weakens the understanding and produces ill consequences in common life. He shows that secular prophecies are forgeries, and proves to his own satisfaction that divine prophecy has ceased. The treatment of the subject, though perhaps considered scholarly in its day, is superficial and shallow. He adds little to what Northampton said almost a hundred years before. 
The parody of the paradoxical vaticination is represented by Sir John Harington's epigram, A Prophesie Asses shall grow Elephants: ${ }^{30}$

"When making harmful gums, unfruitful glasses, Shal quite consume our stately Oaks to ashes;

When Law fills all the land with plots and dashes,

When land long quiet, held concealed passes.

When warre and truce playes passes and repasses,

When monopolies are given of toys and trashes;

When Courtiers marre good clothes with cuts \& slashes,

When Lads shall think it free to lie with Lasses,

When clergy romes to buy, sell none abashes,

When foul skins are made fair with new found washes,

When Prints are set on work with Greens and Nashes,

When lechers learn to stir up lust with lashes,

When plainnesse vanishes vainnesse surpasses,

Some shall grow Elephants, were known but Asses."

This is at the same time a parody on the prophetic form and a satire on the manners of the times.

The Elizabethan dramatists as a rule disapproved of the widespread credence given prophecies, and not infrequently gave voice to their disapproval. Peele in Edward the First takes pains to show how Llewelyn was misled by prophecies which always came true in a way he had not expected. Maximilian in Fletcher's play, The Prophetess, speaks opinions which, though in keeping with the spirit of the play, seem to be an attack on prophecies and prophets. He says:

"Inspired with full deep cups, who cannot prophesy?

A tinker, out of ale, will give predictions:

But who believes?" (Act I, scene iii.)

$\mathrm{He}$ goes further in his tirade and attributes the prophecies to the active malice of the Devil himself. Shakspere introduced into King Lear a parody on the paradoxical prophecy, and showed by the words he puts into the mouth of the speaker his contempt for the whole tradition from Merlin down. The Fool says:

"Ile speak a Prophesie ere I go:

When Priests are more in word, than matter;

${ }^{30} \mathrm{Sir}$ John Harington, Epigrams, I, 83. 
When Brewers marre their malt with water;

When Nobles are their Taylors Tutors,

No Heretiques burn'd, but wenches Sutors;

When every case in Law, is right;

No Squire in debt, nor no poore Knight;

When Slanders do not live in Tongues;

Nor Cut-purses come not to throngs;

When Usurers tell their Gold i' th' Field,

And Baudes, and whores, do Churches build,

Then shall the Realme of Albion, come to great confusion;

Then comes the time, who lives to see't,

That going shal be us'd with feet,

This prophecie Merlin shall make, for I live before his time."

(Act III, scene ii.)

The Raven's Almanac by Dekker has been mentioned, and some idea of its content given. It is everywhere a deliberate parody and burlesque, and in places contains satire on the manners of the times. For instance, the Epistle is a satire on the life of the fashionable young men of the day. The explanation of the zodiacal symbols is at the same time a burlesque and a satire on the absurdity of astrology. The plagues incident to the year are described in the same fashion. In the course of the almanac two stories are told which are satires on women and monks. In this book Dekker was killing several birds with one stone, using a burlesque of the type to satirize numerous abuses of the age.

One result of the long popularity of the Galfridian prophecy in England was that Englishmen became familiar with that style of narration in which symbols not really allegorical are used for real living individuals. This familiarity enabled Robert Greene to use in James the Fourth a bit of narrative in which the names of animals are used for the names of people. Sir Cuthbert Anderson at the close of the play in explaining what had befallen Queen Dorothea says:

"A tender Lyons whelpe, This other day came stragling in the woods, Attended by a young and tender hinde,In courage hautie, yet tyr'd like a lambe. The Prince of beasts had left this young in keepe, To foster up as lovemate and compeere, 
Unto the Lyons mate, a naibour friend;

This stately guide, seduced by the fox,

Sent forth an eger woolfe, bred up in France,

That gript the tender whelp, and wounded it,

By chance, as I was hunting in the woods,

I heard the moane the hinde made for the whelpe;

I took them both, and brought them to my house.

With charie care I have recured the one;

And since I know the lyons are at strife

About the losse and dammage of the young,

I bring her home; make claime to her who list."

The two Lions are the Kings of England and Scotland who each bore a lion in his coat-of-arms. The Whelpe is of course Dorothea, daughter of the King of England. Nano is the hind, Ateukin the Fox, Jacques the Wolf. A change of tense of the first ten lines from the past to the future would make the passage a good Galfridian prophecy.

The same style of narrative was used by James Howell in his Apologs. ${ }^{31}$ The second Apolog, called The Great Council of the Birds, narrates briefly and obscurely the events leading up to the execution of Charles the First. The Eagle once called a general assembly of the birds to hear complaints that the Birds of Prey were doing much damage to the flocks. The complainants forced the execution of the Griffin, and then falling upon the Pies drove them away. At length a rebellion was raised against the Eagle, and many of the flocks deserted. But the Bird with the Golden Wings, the Falcons, the Chough, the Ravens, the Martlets, the Swan, the Birds of the Mountains, and the Ostriches remained faithful. Among the deserters were the White and the Green Dragons. Desertion continued until at last Philomela, the spouse of the Eagle, took fright and fled also. As a rule these different birdnames stand for the noblemen in whose coat-armor the figures appeared. For instance, the Bird with the Golden Wings is the Marquis of Hertford, the Swan the Earl of Worcester, the Griffin the Earl of Strafford. The Pies are the Bishops, and the Mountain Birds the people of Wales. The Eagle is used metaphorically for the King, Philomela for the Queen.

${ }^{31}$ James Howell, Apologs, or Fables Mythologized, London, r66r. 
A similar use of flower-names occurs in the third Apolog called The Parlement of Flowers.

Heraldic symbols used for the names of men run riot in Gower's Cronica Tripertita. No names of men occur in the first part, and few in the later parts. If a symbol is not given, the name is etymologized, as in Bridlington. A change of tense, as in the passage from James the Fourth, would make the whole work an excellent Galfridian prophecy. ${ }^{32}$

Examples might be multiplied. The use of a man's heraldic emblem for his own name came in time to be very common. It was a convenient means of indirect but readily intelligible reference. It appears not only in prophecies and long narratives but in shorter pieces and dedications as well. Skelton in his poem Against the Scottes uses the symbols in the account of Flodden:

"The Whyte Lyon, there rampaunt of moode,

He ragyd and rent out your hart bloode;

He the Whyte, and ye the Red,

The Whyte there slew the Red starke ded.",33

Spenser uses the same convention in Daphnaida, the elegy he wrote on Lady Douglas Howard. In the dedication he says:

"Therefore I doe assure myself that no due honour done to the Whyte Lyon, but will be most grateful to your Ladyship, whose husband and children do so surely participate with the bloud of that noble family."

In the course of the poem he speaks of Lady Douglas as 'an ancient Lion's haire,' and as

\section{"A faire young Lionesse,}

White as the Native Rose before the chaunge."

It will be shown in the next chapter of this study that the Galfridian prophecy was transplanted to the Continent, where

32 The Swan is used throughout for Thomas of Gloucester, the Bear for the Earl of Warwick, the Horse for the Earl of Arundel, the Moon for the Percies, the Boar for the Veres of Oxford, not to mention others. Beauchamp of Bridgenorth is called Baro Pons Aquilonis, Nicholas Brembel Tribulus.

${ }^{33}$ The White Lion is the Earl of Surrey, the Red Lion the King of Scotland. These animal figures appeared on the respective shields of the two men. 
it took root and flourished. In Italy a very interesting convention grew out of the type, and was introduced into England somewhat as an exotic. It was the convention of introducing into the romantic epic a prophecy favorable to the author's patron. Thus in Orlando Furioso ${ }^{34}$ Bradamante visits the cave of Merlin and hears his voice prophesying the future of her descendants, whom Ariosto makes the house of Este. Spenser imitated this in The Faerie Queen. In the third canto of the third book he makes Merlin prophesy the future of the family founded by Britomart and Artegall. The family, of course, was the Tudors, and the patron he wished to flatter Elizabeth herself. The prophecy is in the main direct, but a few symbols are used, such as the Raven for the Danes, the Lion of Neustria for William the Conqueror, and the Castle (Castile) for Philip of Spain. Milton accepted the convention but modified it to suit his peculiar purpose. In the eleventh book of Paradise Lost Michael takes Adam up to a high hill, and sets before him a vision of events until the time of the flood. In the twelfth book the course of events is continued until the time of Abraham. At this point the vision ceases, and Michael explains to Adam Christ's mission on earth.

In closing the study of the political prophecy in England a few words should be said by way of summary. Between the years II2O and II35 Geoffrey of Monmouth introduced into England a new type of literature, the political prophecy which he got by translating some prophecies of Merlin from the Welsh. The kind of prophecy he introduced, the Galfridian, was characterized by an unusual kind of animal-symbolism, which continued to be its most marked peculiarity even to its latest days. Geoffrey had countless successors each of whom used the type to suit his own purposes. Some wrote prophecies as literary exercises; others wrote them as political propaganda. In both literature and politics the influence was far-reaching. In literature, for instance, they produced the conventions of using heraldic symbols for men and their families, and of introducing prophecies into romantic and religious epics. In politics their influence if not directly

\footnotetext{
${ }^{*}$ Ariosto, Orlando Furioso, Canto III, stanza i7 f.
} 
responsible for countless rebellions and insurrections at least was a potent factor. This influence was exerted from the twelfth century even to the middle of the seventeenth century. Although other types of prophecy such as the Sibyllic, the direct, and the rhetorical were used the Galfridian was always predominant. In the course of time the English people began to outgrow this superstitious confidence in prophecies, and the type naturally declined. Parodies, burlesques, satires, and adverse laws became abundant, until the Galfridian type disappeared. Prophecies continued to be written after the year I700, but they observed other forms and other conventions. 


\section{CHAPTER SIX}

The Galfridian Prophecy in other Countries than ENGLAND

The history of the political prophecy in England has been discussed, and the existence of vaticinal literature on the Continent before II 35 has been shown. It is now time to study the Continental prophecies after I I35. The English Galfridian type spread to other countries and maintained itself there side by side with the native Sibyllic type. It became known to the people of Western Europe through quotations and translations of The Book of Merlin and grew so popular that they accepted Merlin as their own and attributed purely local prophecies to him. They early adopted the type itself and wrote prophecies attributed to other prophets than Merlin but conforming to conventions of the type. The wealth of material supplied by this part of the subject is embarrassing, for only a brief survey is possible here. In presenting the material the quotations and translations of The Book of Merlin will be discussed, then the local prophecies attributed to Merlin, and lastly those written according to the Galfridian method. This discussion will be followed by general observations on the history of the type on the Continent.

Merlin's reputation as a prophet was not long confined to England. His prototype, Ambrosius, whose name was combined with his own, had long been known through the work of Nennius. The story of the white and red dragons must have been familiar to readers in Western Europe long before Geoffrey produced The Book of Merlin or the Historia. The name Merlino ${ }^{1}$ was known in Italy as early as the late eleventh century. It is not certain that Geoffrey was the first to associate Merlin with the Arthurian story. Godfrey of Viterbo ${ }^{2}$

${ }^{1}$ See note 42, Chapter 2.

${ }^{2}$ Note 44, Chapter 2. 
gives a version of the story that differs in many ways from Geoffrey's, and makes Merlin a participant in the action. It would seem that there was in existence another form of the story, independent of Geoffrey's, and that it must have served as the source of Godfrey's version. At any rate, Western Europe was to some extent prepared to receive the prophecies contained in The Book of Merlin, especially since they were combined with the familiar dragon-story. It is a significant fact, furthermore, that the earliest notice of The Book of Merlin comes not from an English but from a Continental source.

Merlin and his prophecies were known in Normandy as early as II $35 .^{3}$ By the end of the century, however, The Book of Merlin had penetrated to Central France, and was respectfully received by statesmen, scholars, and chroniclers alike. Fragments from it were often quoted either in the original Latin or in translation. Alanus de Insulis ${ }^{4}$ knew it at first hand before II79. Geoffrey de Bruil in his Chronicle, written c. II 83, quotes as a 'Vaticinium Ambrosii Merlini' the passage relating to the Eagle, ${ }^{5}$ and says that it was thought to have been fulfilled in the marriage of Matilda with Henry the Fifth of Germany. Suger, the eminent statesman and minister of Louis the Seventh, in his biography of this king ${ }^{6}$ quotes at length from the Lion-of-Justice passage, ending with the Nesting of the Eagle. He calls Merlin veracious, and says that not one word of the prophecy has proved untrue. In the next century William Brito ${ }^{7}$ quotes the passage concerning 'the Lynx penetrating all things,' and applies it to King John. This author refers to the passage regarding the taxes of

${ }^{8}$ Chapter I. How much earlier than II 35 they were known is uncertain. The last event narrated by Odericus before he quotes from the prophecies is the death of Duke Robert Curthose, in February, I 134 .

${ }^{4}$ See Chapter 4.

'Geoffrey de Bruil, Chronicle, Pertz, Mon. G. H. XXVI, 20 r f. c. 43. The passage quoted runs, 'Aquila ejus super Aramnum nidificabit.' (Giles, 122.)

- Suger, Oeuvres Complètes. Ed. A. Le Coy de la Marche, Paris I867, p. $54 \mathrm{f}$.

"Chronicle. Ed. H. Francois Delaborde, Paris, 1882 (Soc. de l'Hist. Franc.), p. 293. 
Henry the First. Geoffrey's Latin reads, "In diebus illis aurum ex lilio et urtica extorquebitur, et argentum ex ungulis mugientum manabit." William writes, ${ }^{8}$

\author{
"Olim dominabitur Anglis \\ Argento urticas et lilia qui spoliabit."
}

Alberic Trium Fontium quotes twice the passage relating to the 'favor of newcomers.' In Italy in the thirteenth century Salimbene refers to the passage relating to the Goat and the Castle of Venus. His words are, "Surget yrcus Veneri castri, qui alienum gallum abiciet, federabitur aquiloni, colligabit sibi aquilam." The passage in the Historia runs, "Succedet hircus Venerei castri aurea habens cornua, et argenteam barbam." Nothing is said of the Cock or Eagle. A passage from The Giraldian Collection relating to the murder of Becket, 'the son shall slay the father in the womb of the mother,' is quoted by Baldwin Ninovensis ${ }^{10}$ and Philip Mouskes. ${ }^{11}$

In Italy the record is not so clear, but indirect evidence leads to the conclusion that the Book of Merlin must have been known there during the latter part of the twelfth century. The dragon-story was known, and Merlin's name associated with it, as Godfrey of Viterbo's account shows. Joachim of Fiore $^{12}$ was said by Salimbene to have made in 1196 an exposition of the prophecies of the Sibyl and Merlin. These Dicta Merlini, if ever written, have been lost. Italians of the twelfth century, however, had every opportunity of knowing the Galfridian collection, especially after Alanus had written his elaborate commentary. It is quite within the range of possibility that members of Richard the First's crusading army spread the prophecies or news of them during their stay in Southern Italy. Information concerning them may have come in from Provence where they were certainly known early in

${ }^{8}$ Philippidos. Book VIII, 1. 906, ed. ibid., Paris, i885, p. 244.

${ }^{\circ} N$. A., vol. 15, 175.

${ }^{10}$ Chronicon in Corpus Chronicorum Flandriae, ed. J. J. de Smeo, 2 vols., vol. 2, Brussels, I84I, p. 7 I 2 .

${ }^{11}$ Mouskes. Chronique ed. Le Baron de Reiffenberg, 2 vols., Brussells, 1836-38, Vol. II, p. 260.

${ }^{13}$ Holder-Egger, Neues Archiv d. Gesch. f. alter. d. Gesch., I5. 
the next century. ${ }^{13}$ Evidence abounds for the thirteenth century although the present writer has found no quotations from Geoffrey's collection in Italian writers. Prophecies ascribed to Merlin are frequent. Many prophecies answering the requirements of the Galfridian type are found. Merlin himself was quoted in disputes as having equal authority with Daniel and Isaiah.

The evidence for Germany is even scantier. Godfrey of Viterbo may have spread some knowledge of Merlin and the prophecies during his residence there, but this is merely a possibility. The commentary on The Book of Merlin by Alanus de Insulis may have helped, since Alanus was a famous scholar and his works may reasonably be supposed to have interested other scholars in Western Europe. The redactors of the Chronicle of Alberic Trium Fontium knew at least the two prophetic fragments quoted therein. ${ }^{14}$ Richard of Ireland, a member of Frederic the Second's court, produced some Prophecies of Merlin, which, however, have no relation to Geoffrey's Collection. They concern Italian affairs, and were probably written in Italy, not in Germany.

Interest in Merlin was not confined to the Continent. ${ }^{15}$ The

${ }^{13}$ Chronicle of the Albigensian War, asc. to William of Tudela, ed. Paul Meyer, 2 vols.; Paris, 1879, vol. 2, p. I93 n.

${ }^{14}$ Pertz. Mon. Ger. Hist., XXIII, 631-950, under the years II 36 , II 38 .

${ }^{15}$ The early manuscripts containing the Historia with the Prophecies in the Seventh Book or the Prophecies separate from the Historia are widely scattered. Of twenty-eight manuscripts of the Historia (Hardy T. D.Descriptive Catalogue of Materials Relating to the History of Great Britain and Ireland to the end of the reign of Henry VIIIth. R. S., I862, London, vol. I, p. $34 \mathrm{I}$ f.) dating from the twelfth century two are found in the Library of the Ecole de Medicine at Montpellier, one in the Library at Lille, one in the Christiana Library of the Vatican, one in the Laurentian Library in Florence, and one in the Monastery of Saint Mary in Florence. Of twenty-nine manuscripts of the Historia belonging to the thirteenth century six are in the Bibliothèque Nationale in Paris, one belongs to the Library of St. Geneviéve in the same city, one is in the Vatican, one in Berne, one in Brussels, and one in Stockholm. Hardy mentions only a few manuscripts that contain the Prophecies alone. He shows two of the thirteenth century and one of the fourteenth century in the Bibliothèque Nationale. These manuscripts doubtless have 
Book of Merlin made its way to Iceland very early, and was translated into Icelandic by Gunnlaug Leifson, who died in 1218 or 1219. ${ }^{16}$ This Icelandic translation brings up the question of other translations of The Book of Merlin. The various redactors of the Historia omitted the prophecies because they could make nothing of them. Wace spoke for all when he wrote after the account of the dragon $:^{17}$

"Donc dist Merlins les profesies
Que vous aves sovent oies
Des rois, qui a venir estoient
Qui la terre tenir devoient.
Ne voil son livre translater,
Quant jo nel' sai entepreter;
Nule rien dire ne volroie
Qu' essi ne fu com jo diroie."18

The prophecies are not found in the Arthurian Romances, not even in the Romance of Merlin, where one would most expect them to occur. The Merlinusspá, as the Icelandic version is called, is a poem inserted in the Bretasögur, but it is older than the context in which it occurs. ${ }^{19}$ It consists of two parts, the first containing the fourth chapter of Geoffrey's second book, the second answering to Geoffrey's third chapter. "The first four strophes of what ought to be Part II reintroduce Merlin, as if he was quite unknown to the reader; and this perhaps led Hauk Erlendsson to consider it as Part I.",20

Geoffrey's Prophecies of Merlin were translated into Bournot been in these libraries ever since the twelfth and thirteenth centuries, but in all probability some of them reached the various countries shortly after they are written.

${ }^{16}$ Ward, loc. cit., I, 304 .

${ }^{17}$ Wace, Roman de Brut, 1. 7729 f. Ed. Le Roux de Lincy, 2 vols., Rouen, $18{ }_{3} 6$.

${ }^{18}$ The prophecies were turned into Anglo-French and inserted into some mss. of Wace, as in a ms. belonging to Mr. D'Arcy Hutton. (Société des Anciens Textes Français, Bulletin, 1882.)

${ }^{19}$ Eugen Mogk, Paul's Grundriss, 1909, 2, I, 2, p. 7 II ; H. G. Leach, De Libello Merlini, Modern Philology, vol. VIII, p. 607 f. Leach thinks that Lincoln may have served as the point of exchange.

${ }^{20}$ Ward, I, 305. 
bon French in the fifteenth century by Jehan Wauquelin, or Waurin, of Mons. Waurin made at the request of his nephew, Waleran de Mons, a collection of the chronicles of England, and began his work by translating Geoffrey's Historia. ${ }^{21} \mathrm{He}$ says in the General Prolog that he determined about the year I 455 to undertake the work, and to bring it down to the coronation of King Henry the Fifth. ${ }^{22}$ The Collection of Chronicles is divided into five volumes, of two or more books each, and each book into several chapters. The whole of Geoffrey's seventh book is contained in three chapters, beginning with the fifty-fifth, of the second book of the first volume. After translating the Prolog and the Epistle, Waurin interjects a few remarks of his own. He says:

"What marvel then that I, feeble and dark through the obscuration of the flesh, which binds and oppresses my faculties, and increases the dulness of my poor and idle intellect, should put forward my excuses, most legitimate, when apologies are offered by this high Latinist, whose thoughts glow with harmonious colours and with golden words of Tullian splendour, his rhetorical excellence making my talent shrink as does the eye before the solar ray, covering itself with its lids. By ambiguous ecstacy, yea and the suspended construction of the sentences, and especially in those prophecies where Merlin gives his meaning by poetic fiction and under a metaphorical covering, which are unintelligible to my understanding, and invisible through the opacity of my body, for they exceed its capacity, and then by stronger reason it is very difficult to expound them in appropriate French, as the abundant and ready eloquence necessary is not given me. But, nevertheless, my native Bourbon language, though rude, shall well suffice, please God, to make known, as best I can, the sense of the author, explaining it where it is obscure, more largely than his words suffice to convey the meaning. And even as regards those prophecies where the sense is obscured by a metaphorical and fallacious

${ }^{21}$ Edited with a translation by William Hardy, R. S., I864.

${ }^{22}$ Hardy printed from a fifteenth century manuscript in the Imperial Library at Paris, now in the Bibliothèque Nationale. According to a statement made at the close of a manuscript in the British Museum (Ward I, 25I) the work was begun on July 25, 1445, at the request of Monsieur de Croy. This seems to have contained only the translation of the Historia and may therefore have been an earlier work. The continuation to the time of Henry the Fifth may have been begun in 1455 as the French manuscript says. But the statement at the close of the English manuscript may have been made by the scribe on his own authority. Ward makes no mention of Hardy's edition of the whole work. 
covering, I will explain them in easy and intelligible French, according to the extent of the faculty of my small intellect, by clear and distinct exposition; wherefore I pray all those who may read this book, that if they find in it anything badly said they will pardon it, and for what is good they will give God the praise."23

In dealing with the prophecies Waurin translates an episode, and then expounds it. He does not interpret any episode after the Conquest in the light of history. His explanations are usually childish, ludicrous, or absurd. ${ }^{24} \mathrm{He}$ moralizes at every opportunity. His rendering of his original in some places indicates that he used a text different in minor details from that printed by Giles. For instance, he translates the beginning of the Lion-of-Justice episode, "The lion shall succeed to the leopard of gladness, through whose roaring the Gallic towers and the barons of the isles shall tremble." Later he speaks of this Lion as the Lion of Justice. The Leopard of Gladness is not mentioned in Giles's text. The latter also reads 'dragons of the isles' which Waurin may have deliberately changed in his translation in order to save the trouble of interpreting it. He makes Sextus a foreign chief from Ireland, who has the character of a Lynx. The successor of the Lion of Justice he makes the old man of Periron. Similar divergences occur throughout.

No other translations of The Book of Merlin have been found in the course of this study, though some may exist. Collections of prophecies attributed to Merlin are rather frequent, but one must see them before he can know what they contain. For instance, one large collection, which will be discussed later, was made up on the Continent and translated into several languages, but it has nothing in common with The Book of Merlin. The same is true of the Romance of Merlin. What the fifteenth century German "Bearbeitung" of Merlin ${ }^{25}$ contained does not appear from the brief description of it.

By the end of the twelfth century Merlin's fame as a prophet had become universal in Western Europe and The Book of Merlin was known either through quotations or by general

${ }^{23} \mathrm{Hardy}$, trans., vol. I, p. 200.

${ }^{24} \mathrm{Cf}$. his explanation of the Dams 21 of the Damneian Forest.

${ }^{25}$ Greith, Spicilegium Vaticanum, p. 86. 
repute. France and Italy adopted him, and attributed to him prophecies relating to local affairs. This was the second step in the spread of the influence of the Galfridian prophecy which had arisen in England, the domestication of the type in foreign countries.

In France the evidence consists mainly of single sentences quoted by chroniclers or by other writers. Mouskes ${ }^{26}$ quotes or alludes to two; one is to the effect that the Lord of Halberdiers would die at Martiaus, which was accomplished in the death of Henry, the son of Henry the Second: the other says that at Limoges should be forged the chain with which the tyrant coming from England should be chained, a prophecy which was supposedly accomplished in the death of Richard the Second at Limoges. Johannes Longus in the Chronicle of St. Bertin ${ }^{27}$ quotes a prophecy of Merlin that the upright lion should die on Monteveltris. This was applied to the death of King Louis in 1226. Another French prophecy attributed to Merlin in the thirteenth century occurs in Reçits d'un Menestral de Reims. ${ }^{28}$ It declared that two Lions of France should die at Montpensier.

During the thirteenth century a French version of the prophecies of Merlin was produced. According to a statement in the manuscript they were translated from the Latin by Richard of Ireland. After Richard had begun his work, Frederick the Second had occasion to test the truth of the prophecies, and, finding them true, encouraged him to continue his work. In the French manuscript they follow the Roman de Merlin. ${ }^{29}$ According to Ward's description ${ }^{30}$ of a version in an English manuscript, the prophecies are scattered among chivalrous romances. The origin of the Latin source for this

${ }^{26}$ Philip Mouskes, ed. Reiffenberg, Brussells, $183_{3}^{6} 6-38,2$ vols.; vol. 2, p. 272,3 I2.

${ }^{27}$ Johannis Iperii, Chronicon St. Bertini, XLVI, part 21, in Martene and Durand Thesaurus Novus, Tome III, Paris, I717, c. 207.

${ }^{28}$ Reçits d'un Menestral de Reims. Nalatis de Waelles. Paris, 1876 (Soc. de l'Hist. Fran.), p. I74.

${ }^{29}$ Les Manuscripts François de la Bibliothèque du Roi. Ed. Paris, vol. I, Paris, 1836 , p. $129 \mathrm{f}$.

${ }^{30}$ Ward I, 37 I f. 
translation seems unknown. It served as the basis of a larger collection which appears in French and Italian, and which was very frequently printed in the fifteenth and sixteenth centuries. This collection for convenience will henceforth be called The Continental Collection. Discussion of it, however, must be postponed to another paragraph. Froissart may have referred to it when he wrote that a prophecy relating to a coming savior of France was to be found in the thirty-eighth chapter of Merlin's prophecies. ${ }^{31}$

One thing is clear. Merlin was well known as a prophet in France during the thirteenth and fourteenth centuries. Deschamps in a ballade, Contre l'Angleterre, ${ }^{32}$ written in 1385, names Merlin with Bede and the Sibyl as having prophesied a French victory over the English. The prophecies of Merlin were said to have been consulted by Du Guesclin before the battle of Auray. ${ }^{33}$

If the local French material attributed to Merlin is somewhat scanty, evidence of Merlin's influence in Italy is abundant. Italians adopted the Welsh prophet as their own, and placed him in their esteem among the prophets of established reputations. In a dispute that occurred in 1248 at the Minorite convent at Hyeres between Hugh of Bariol and Peter of Apulia, Hugh quoted Merlin's prophecies as of equal weight with Isaiah's. ${ }^{34}$ When Peter objected, saying that it was wrong to quote Merlin, an unbeliever, Hugh exclaimed: "You lie, and I can prove it. Does the Church reject the prophecies of Balaam, or Elihu, or Caiaphas, or the Sibyl, or Merlin, or Methodius? Good things must not be scorned, even though they come from a bad teacher."

The exposition of Merlin's prophecies which Salimbene said was made by Joachim of Fiore has been mentioned earlier in this chapter. Prophecies ascribed to Merlin were common

${ }^{31}$ Chroniqueurs et Trouveres Belges, Brussels, 1869, 8, 418.

${ }^{32}$ Deschamps, Oeuvres Complètes. Ed. Marquis de Queux de St. Hilaire, vol. I, Paris, I878, p. I06.

${ }^{33}$ Pradière, La Bretagne Poetique, Paris, 1872 , p. 93.

${ }^{34}$ T. L. Kington, History of Frederick the Second, vol. 2, London, 186.2, p. 477, quoting Salimbene. Referred to by Ward, loc. cit. I, 372. 
enough in the thirteenth century. The Verba Merlini, ${ }^{35}$ which were quoted by Hugh of Bariol, are at least as early as I248. They are short, and relate to Frederick the First, Henry the Sixth, and Frederick the Second. The emperors are designated by their initials according to the Sibyllic method. Animal names occur, but they are more metaphors than vaticinal symbols. Frederick the First is described as 'in pilis agnus, in villis leo'; Frederick the Second as 'inter capras agnus laniandus'; a son of his is promised he shall be a 'leo rugiens' among his brothers. Thomas of Pavia ${ }^{36}$ quotes another prophecy of Merlin concerning Henry the Sixth, but it has not been found in any collection attributed to Merlin. Salimbene quotes at length the Versus Merlini, ${ }^{37}$ a poem sixty lines long and containing predictions on various Italian cities. So far as can be determined from the ten lines quoted by Holder-Egger, the prophecies contained in the $\mathrm{Ver}$ sus were not Galfridian.

Genuinely Galfridian is the Profetia Merlini beginning post galli fugam, which dates from the late thirteenth century. ${ }^{38}$ The action begins with the flight of the Cock into France (galli fugam in Galliam). A city known by the name of its river grows proud, and is besieged; all Liguria trembles; the Dragon is attacked; Emilia is brought to her former weakness. Then a Wicked Boar departs, slaying some of his captives, and taking others with him. His Chick (pullus), born of a concubine, is captured, and put in prison in the Nest of Philosophers. This seems to bring on a general war. The Cock returns, and temporary peace is made. But war is renewed in which the Cock, the Lion, the Asp, the Wolf, C., a Bull, a Goat, a Fox, a Mare, and a Lamb, all seem to take part.

Similar to this is the Profezia Merlini inventa et rescripta a quodam antiquo libro, ${ }^{39}$ which is found in a fifteenth century manuscript. According to it there should come from the dis-

${ }^{35}$ Holder-Egger, Neues Archiv, $30 ; 379 ;$ ibid., $15 ; 175$.

${ }^{36}$ Pertz, Scriptores Rerum Germaniae, Thomas Tuscus, XXII, 515. Referred to by Holder-Egger.

${ }^{37}$ Holder-Egger, N. A., $30 ; 378$ f.

${ }^{38}$ Sanesi, supra, p. cv, printing from Cod. Laurenz., Pent. XVIII, sin.

${ }^{39}$ Kampers, 151 . 
tant mountains a Lion with a forked tail, who had wedded an Eagle. He should call to his assistance a swift Forest Leopard. A Bear, a Wolf, several Dogs, and a Fox all join in the action, which seems confined to Lombardy, centering around Milan and Verona. A note interprets the Lion as Robert of Naples.

Three prophecies in Italian are found in manuscripts ${ }^{40}$ written at Florence in 1442 according to a statement made at the end of each. Two deal with the same material, one being a longer and more complete version than the other. Both are said to have been delivered by Merlin to Master Anthony, who wrote them down. The third is said to have been dictated to Master Basil. All three are in dialog form; the scribes put questions, and the sage makes his prophecies in answer to them. Galfridian symbols are used in all. In the longer of the Anthony prophecies the explanation of each symbol follows it in brackets, and a key to all is added at the end of the prophecy. Here the Cock represents the Pope, the Lion Florence, the Prancing Horse Arezzo, the Panther (Pantera) Lucca, the Wolf Sienna, the Bear Pistoia, the Wild Goose Orvieto, the Panther (Lonza) Paris, the Viper Tuscany, the Leopard Viterbo, the Unicorn Lamagna, the Tail of the Black Eagle the nobles of Rome, and the Elephant Rome herself. In form these prophecies resemble very much the Continental Collection, and may perhaps occur in it. They contain references to the Champion, who also appears in the Collection.

Before going further it is well to review here the Continental prophecies of the twelfth century, in order that one may see clearly how new the Galfridian form was to Western Europe. The chief pieces of vaticinal literature then current were the Book of Methodius, various versions of the Last-King-of-Rome story, and the Prophecy of Sibyl Tiburtina, in which the details did not remain constant. The general method of all these prophecies was the Sibyllic initial-reference. If animal names occurred, they were used as metaphors, and not as Galfridian vatic symbols. The Sibyl's repute was widespread. Prophecies were freely attributed to her in the various countries.

In Germany the Sibyllic tradition lingered long, and found

${ }^{40}$ Sanesi, cvi f. 
expression as late as the fourteenth century in the Sibillen Boich. ${ }^{41}$ This is a poem of a thousand and forty lines, which combines the stories of the Queen of Sheba and of the Holy Rood. The first part deals with the history of the Rood Tree from the time of its planting on Adam's grave until the building of Solomon's Temple, at which time the Tree was used as a bridge. The second part tells of the Sibyl's visit to Solomon. Coming once to this bridge, she turned aside and waded the stream, whereupon as a reward for her consideration her web foot was changed to a human foot. When asked by Solomon why she refused to cross the bridge, she gave him the history of the Tree until the Crucifixion. The third part contains Solomon's questions and her prophetic answers, and gives a history of the world to the Judgment. Some manuscripts contain here an interpolation, written in true Sibyllic method of initial-reference, which narrates briefly the history of Germany from the time of Emperor Adolf, I298, to Charles the Fourth, I349. Vogt ${ }^{42}$ thinks the poem written before the time of Charles whose name he considers an interpolation in the prophecy. In an earlier version victory is promised to Frederick of Austria. This must have been written before the latter's defeat in I322. In the Chronik des Stiftes S. Simon und $J u d a s^{43}$ of the thirteenth century reference is made to a prophecy of a Sibyl that there should come a king who should rule the Roman Empire like a fox, possess it like a lion, and guard it like a dog. The old Prophecy of Sibyl Tiburtina dealt to some extent with the German Emperors to Henry the Sixth, and belongs to the twelfth century. Still earlier than this Otto of Freising had quoted in his Chronicon ${ }^{4}$ the celebrated acrostic of the Sibyl, and had added to his account of it the statement that the Sibyl was said to have prophesied the Trojan War.

Local Galfridian material in Germany is scarce. What the

${ }^{41}$ L. Schade, Geistliche Gedichte, Hanover, I854, p. 29 I f.

${ }^{42}$ Vogt, Ueber Sibyllen Weissagungen, Beiträge zur Geschichte deutschen Sprache und Literatur, vol. 4, Halle, 1877 , p. 48 f.

${ }^{43} \mathrm{~L}$. Weiland in Monumenta Germanica Historica, Deutsche Chroniken

II, paragraph I 3 .

${ }^{44}$ In Scriptores Rerum Germaniae, Hanover, 1867, p. 65. 
Bearbeitung, previously referred to, contains, the present writer does not know. The prophecy said to have been sent to Germany by Cardinal John of Toledo contained Galfridian symbols. The Lion of France represented Charles of Anjou, the Eagle's Chick Conradin, and the Branch from the Root Frederick of Antioch. Another prophecy, found in the Chronik Ebensdorfers, ${ }^{45}$ seems to be another version of the same material. The Lion, the Eagle, the Eagle's Chick, a Leopard, and the Branch from the Root appear in it. The final victory is promised the Branch (here, however, Radix ex radice) who seems to represent Frederick of Austria. Doubtless other material exists. The piece which was described in the second chapter of this study as A Prophecy of the German Emperors is sometimes attributed to Saint Hildegard, and considered a German prophecy. ${ }^{46}$ Her death in II 78 gives an approximate date for it, if it be considered hers.

In France, as was shown in the second chapter of this study, prophecies were attributed to the Sibyl from an early date. Fredegarius quoted one concerning Brunehild. Sedulius made a collection of the Sibyl's prophecies. The Book of Methodius was known through a Latin translation. An interpolation into Adso's De Anti-Cristo brought Frenchmen into contact with the C., or Constans, Prophecy that the last King should bear the name Constans or a name beginning with $C$. Kampers ${ }^{47}$ says that this prophecy was applied to Charles Constantine, the son of Louis the Blind, and shows that the Sibyl Tiburtina named the descendants of Boso of Arles after Louis. The Sibyl's repute was established. Deschamps names her with Bede and Merlin in the ballade, Contre l'Angleterre, as a prophet of indisputed authority. A prophecy on French affairs entitled L'Epistre de Sibille, was written in the fourteenth century. ${ }^{48}$ It begins, however, in good Galfridian fashion, " $l a$ lupart en assaillant la roiaume de France." A prophecy on Henry the Fourth was attributed to the Sibyl, but although it

\footnotetext{
${ }^{45}$ Kampers, I 28.

${ }^{46} \mathrm{Vogt}$, loc. cit., p. 93.

${ }^{47}$ Kampers, p. $45 \mathrm{f}$.

${ }^{48}$ Ward, I, 222.
} 
does not contain Galfridian symbols, it is not written according to the genuine Sibyllic method of initial-reference.

The French do not seem to have been so deeply interested in prophecies as the English and the Italians until rather late; at least, the evidence that shows interest is somewhat scanty. According to this evidence the writing of prophecies in the Sibyllic method did not survive the twelfth century in France. L'Epistre de Sibille is really a Galfridian prophecy. In fact, the French seem to have adopted the Galfridian method exclusively when they wished to use symbols. The fragmentary thirteenth century prophecies of the Lion who should die at Montveltris, and of the two Lions who should die at Montpensier have been referred to earlier in this chapter. They conform to the Galfridian type. The prophecies of the cerf volant and the ane pesant, quoted by Deschamps ${ }^{49}$ are additional examples. The Prophetie d'Orval, written in 1544 by Phillip Olivarius, spoke of the Eagle, the White Flower, the Cock, and the Lion. The Prophecy of St. Cezaire, found in the Mirabilis Liber, treated among other things of a Black Eagle and a Lion from a Far Country. The Prophecies of Merlin ${ }^{50}$ speak of a Bird to be hatched in a tree, a Beast from the deserts of Babylon, and a Fish from the River Jordan. Nostradamus in his Centuries used animal symbols very freely.

In Italy the Sibyllic tradition, which had always been very strong, produced The Prophecy of Sibyl Tiburtina, which is chiefly concerned with Italian affairs. It was re-written or continued from time to time, one continuation extending to the time of Godfrey of Viterbo in the late twelfth century. The stories of the other Sibyls were never forgotten. When a fresh impulse was given to vaticinal writing by the coming of Geoffrey's Merlin, new prophecies were written and attributed to other Sibyls. Throughout the Middle Ages and well into the Renaissance, the Sibyl, or Sibyls, was held in high repute, and prophecies attributed to some Sibyl were printed. It has already been shown that Hugh of Bariol referred to the Sibyl as being received by the Church as a genuine prophet.

${ }^{19}$ Oeuvres Complètes, I, I64; II, 57-58.

${ }^{50}$ Published as a part of the Bibliothèque de Romans, Paris, 1775 . 
Among the new prophecies written after the advent of Merlin, the Prophecy of Sibyl Erithrea ${ }^{51}$ holds an important place. It, however, continued the Sibyllic tradition only in its name; in the treatment of its material it is genuinely Galfridian. According to Salimbene it is the Expositio Sibille written in I 196 by Joachim of Fiore at the request of the Emperor Henry the Sixth, and dedicated to him. This cannot be quite true, for internal evidence shows that it must have been written in the second half of the thirteenth century during the civil wars attending the extinction of the Hohenstaufen dynasty. Needless to say, it is the work of the Minorites in Italy who foisted it on the dead Joachim. He had dedicated to the Emperor Henry an Exposition of the Apocalypse.

According to a caption at the beginning, the Prophecy of Sibyl Erithrea was taken from the Vasilographos (the Imperial Book), which Sibyl Erithrea of Babylon made at the request of the Greeks during the Trojan War, and which Vedoxa translated from Chaldaic into Greek. A certain Eugenius of Sicily then translated it from the Greek into Latin. It begins, "You ask me, Illustrious People of the Greeks, to commit to writing the Greek fortunes and the Phrygian disasters, and what Fate has in store for the noble progeny of Laomedon, the excellent leader Dioneus, and the House of Teucer, and the young woman in dispute."52 The Sibyl grants the request, and proceeds to tell the history of the world from the Fall of Troy to the Judgment. Animal symbols are freely used. But a new convention is adopted, perhaps at a suggestion from The Book of Daniel. The number of years allotted a ruler is shown by the number of feet attributed to the animal which stands as a symbol for him.

After mentioning the heroes of the Trojan War, the prophecy treats briefly the career of Alexander the Great, calling him the Goat, perhaps at a suggestion from The Book of Daniel. Hannibal is then mentioned, and the rise of Rome told.

${ }^{51}$ Holder-Egger, N. A., I5, p. 146 f.

${ }^{62}$ Exquritis me, o illustrissima turba Danaum, quatinus Graios eventus Frigiasque ruinas in scriptis referam, quidve proli Laumedontidi nobillissime: quid Dioneo duci pollitissimo, quid Teucricis edibus iuvenceque litigii predestinatum existat. 
Pompey and Caesar are called Lions, Augustus the Peaceful Bull. The next event mentioned is the establishment of the Church by Constantine. It is told thus: "But the days shall come in which the virtue of cleansing will be shown in the waters, and a royal Lion (Constantine) shall be changed into a Lamb who will enlighten the world and overthrow kingdoms. A Cock, sitting on a few eggs (Pope Sylvester), shall be clothed in the spoil of the Lion, and black shall be changed into red." The transfer of the Empire to Constantinople is then mentioned, and the history of the Comnenian dynasty told. The narrative is occasionally broken by references to Charlemagne, Frederick the First, and Constantia of Sicily, the wife of Henry the Sixth. Attention is then given to Frederick the Second, and the narrative continues with the history of Italy under him and his descendants. The commentary breaks off with Conrad the Fourth, erroneously called Conrad the Second.

This version is rather long. A shorter one ${ }^{53}$ was made by the followers of Joachim, called Joachites by Holder-Egger, perhaps by Hugh of Die who Salimbene says was interested in these prophecies. After the introduction, it begins with the establishment of Christianity, and follows the longer version with some omission and much condensation. The phrasing is often very different from that of the longer Prophecy.

Salimbene quotes a Prophecy of the Sibyl Samia. ${ }^{54}$ This is very short and indefinite in its statements. "A young Lion shall arise and seek the mountain peaks. He shall be joined by a Fox, and be clad in the skin of a Leopard." It ends, "Honor shall be turned into shame, and the joy of many into sorrow."

The Galfridian method is used to some extent in the Prophecy of Michael Scotus.5 ${ }^{55}$ This is a Latin poem of eighty-seven lines, which attempts to tell the history of various cities in Northern Italy. Serpents, vipers, dragons, the Cub of Verona, and a Griffin take part in the action. Most of the prophecy, however, is direct. The symbols occur only in passages of one or two lines.

\footnotetext{
${ }^{63}$ Nenes Archiv, 30, 523.

${ }^{54}$ Neues Archiv, 15, 177.

${ }^{65}$ Neues Archiv, 30, 358 f.
} 
Other prophecies dealing with Italian affairs belong to the Galfridian type. One ${ }^{56}$ relates to a Northern Eagle who should come into Liguria, and build there his nest. At the same time there should be two Husbands, one the Lawful, the other the Adulterous. At the Eagle's coming the Lawful Husband should flee, and not be found. Then a Gallic Lion should rise against the Eagle, and strike his head, whence a great war should arise. The Lawful Husband should return, and place the Lion in his kingdom, thus restoring peace.

Another prophecy ${ }^{57}$ tells of a Griffin born in France, who should come into the East dragging a long tail. The Emperor should find a Viper among the Caverns. The Leopard should arise with the Eagle of the North, and a general war should follow, in which the Leopard should be the victor. The spirit of this prophecy seems to be Anti-Papal, for the Church is called 'pars diabolica quae Ecclesia vocabitur.'

It is now time to take up the question of the Continental Collection of Merlin's Prophecies. This Collection had appeared first in the thirteenth century in French by Richard of Ireland, who was said to have translated it from the Latin at the request of Frederick the Second. According to a statement in the French manuscript it was first in Latin, and was then translated into French by Richard of Ireland. Sanesi, ${ }^{58}$ however, insists that these prophecies are not to be considered French material at all, saying that they are Italian in authorship, place of composition, and contents. All this is quite true, for they were produced at Frederick the Second's court, by his secretary. According to a fifteenth century manuscript in Italian, ${ }^{59}$ Richard translated the Prophecies while in Catania, and sent a French version to the King of France, a Saracen, or Arabic, version to the Sultan of Babylon, and the Latin version to the Pope. It is impossible to determine anything about the original. The Collection seems to have existed only in the French form until I379 when it was translated from the French, according to a statement in the Italian version, into

${ }^{58} \mathrm{~J}$. Wolf, Lectionum, I, 602.

${ }^{57} \mathrm{~J}$. Wolf, Lectionum, I, 602 .

${ }^{\text {ss }}$ Sanesi, lviii.

${ }^{59}$ Sanesi, xli. 
Italian from a book belonging to Piero di Giorgio Delfino. ${ }^{60}$ The earliest printed edition was the Italian version, published at Venice in 1840. The French version was published twice in 1498 at Paris. A Spanish version was published at Burgos in the same year. ${ }^{61}$

The French collection published in $15^{26^{62}}$ is a medley of material of all sorts. The prophecies contained in it resemble only slightly and in very few instances those found in Geoffrey's Historia. The compiler seems to have worked from some original, for constant references are made to it, such as "le compte dit." The prophecies quoted at various places in the prose Romance of Merlin ${ }^{63}$ seem to belong to this cycle. The Collection begins with a piece of narrative in which it is shown that Merlin is in Galicia in the room of Master Tholomer, and that he is reflecting. Tholomer begins to ask questions. "Of what are you thinking so long?" he asks. Merlin replies, "I am thinking of the countries that shall be in the world I277 after the birth of Christ." ${ }^{4}$ He then speaks of the corruptness of the world, and prophesies the approach of AntiChrist, who is always called the Dragon, or the Dragon of Babylon. This prophecy for 1277 is immediately followed by one for I489. No respect is had for chronology. Prophecies of all kinds and of all countries are loosely jumbled together, and crammed into the book. The prophetic strain is frequently interrupted by long pieces of narrative, of which some relate to the careers of Merlin, Tholomer, and Antony, and others are really romances of chivalry, something like the episodes in Malory's Mort D'Arthur.

The material embodied in this Collection was not absolutely unknown during the centuries before it was printed. Several prophecies written in the characteristic dialog form but with more animal symbols have been described in this chapter. It has just been said that the prophecies in the prose Romance of

on Sanesi, L f.

${ }^{61}$ Brunet, Manuel de Libraire, Paris, 1862, III, I657 f.

${ }^{6}$ No earlier edition could be consulted for this study.

${ }^{83}$ E. E. T. S., I, 305, 316, 435 ; II, 315.

et The Birth of Christ is always referred to thus; la chose qui jadis nasquit aux parties de Jerusalem. 
Merlin belong to this cycle. This Collection was known in England in the early fourteenth century. Robert of Brunne in his Story of England, after telling of the fight between the two dragons, omits the prophecies, saying: $:^{65}$

\footnotetext{
"benne seyde Merlyn many thynges,

What yn bis lond schuld tide of kynges, bat are in Blase bokes write,bey at hauyt, mowe hit wyteAnd in Tolomer \& sire Amytayn; byse hadde Merlynes bokes playn, ffor byse bre write his prophecyes, And were his maistres in ser partyes."
}

He says further that he has not wit to undo the knots that Merlin knit, for he spoke in such a way that till that thing happened, nobody knew it. Blase, perhaps, corresponds to Basilius, who wrote down one of the 1442 prophecies. The editor of Robert queries Auntayn for Amytayn, and is probably correct.

The practice of writing prophecies by means of pictures was not unknown on the Continent. Paracelsus published a series of thirty-two with accompanying explanations, which were originally written in German, but which were translated into Latin with a marginal gloss by David Sebram of Neuburg. ${ }^{66}$ Animal figures occur in some of the pictures. Heraldic symbols also are used, as the Lily for France. A prophetic picture seems to have engaged the interest of different wise men. Carion and Capistranus both made explanations, which, however, proved untrue. ${ }^{67}$

There is noticeable throughout the period extending from the second quarter of the twelfth to the end of the seventeenth century an interchange of prophetic material. European prophecies were known in England, but they seem not to have been turned to any local use. Among these may be mentioned the Prophecy of Sibyl Samia, the Flyting Verses between Frederick the Second and the Pope, the Methodius prophecies,

\footnotetext{
${ }^{65}$ F. J. Furnival in Rolls Series, London, I887, I, $288 \mathrm{f}$.

${ }^{60}$ Wolf, loc. cit., II, 484-50I.

${ }^{67}$ Wolf, loc. cit., I, 824,825 .
} 
and the vaticinal lines beginning, Gallorum levitas. The prophecy of the Unicorn from the West, if not an English production, may also be added to the list. It is a rare instance of a foreign prophecy dealing with English affairs.

Quotations from Geoffrey's collection in European writings have already been discussed in this chapter. Froissart knew something of The Six Kings, for he tells an instance of a Frenchman's quoting the episode that the Boar of Commerce should whet his tusks against the gates of Paris as proof that Edward the Third should capture Paris. ${ }^{68} \mathrm{He}$ also quotes the Triangle Prophecy which was current in England during the reign of Richard the Second. ${ }^{69}$ But Deschamps offers more interesting examples. In his ballade, Contre l'Angleterre, ${ }^{70}$ he quotes a prophecy to the effect:

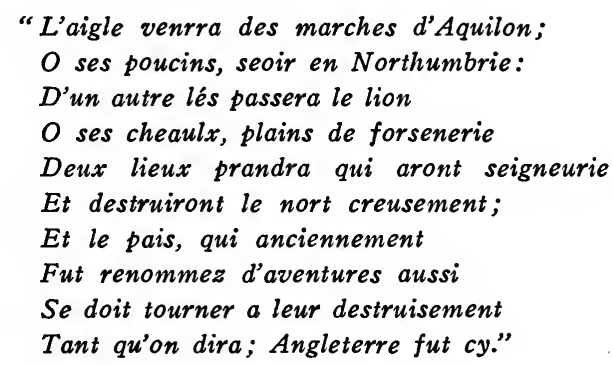

These lines seem echoes of The Six Kings and of The Cock in the North. In another ballade ${ }^{71}$ he speaks of the Ass with the Leaden Foot, certainly a reminiscence of the Six Kings. Rupescissa $^{72}$ had spoken of a great English King who should win the Holy Sepulchre, an episode in the career of Edward the Third, according to The Six Kings.

On the Continent more frequently than in England vaticinal works were published under the names of contemporary men, who set themselves up as prophets either because of some

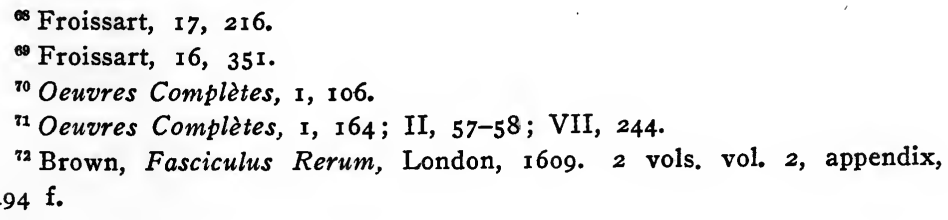


special divinatory powers possessed by themselves, or because of their ability to interpret prophecies already in existence. False attribution, as in the case of Joachim of Fiore, must, however, be guarded against. Without any discussion as to the genuineness of the attribution, the names of men who were known on the Continent as prophets by reason of vaticinations produced under their names may be mentioned here. ${ }^{\mathbf{3}}$ In Italy among others were Telesphorus da Cosenza, Michael da Leone, Anselm da Marsica, Dolcino, and Ardenta da Parma, if one does not include among the Italians Michael Scotus, the astrologer of Richard the Second. In France may be named Richard Roussat, Pierre Turrel, Jean Muller, Michel Pirus, John de Rupescissa, Phillippe Olivarius, and Nostradamus, some of whom were professional astrologers. In Germany may be mentioned Gamaleon, Alfresant, Lichtenberger, Carion, Capistranus, Grebner, Paracelsus, Wolfgang Aytinger, Veit Arnpeck, Grunpeck, and Paul of Middleburg. Of all these Grebner is the only one concerned to any degree with the history of the prophecy in England. The pictures of Paracelsus have been discussed. Nostradamus has been mentioned as using Galfridian symbols. With the exception of these men and Carion, Capistranus, and Rupescissa the present writer has no first-hand information, and does not know what their books contained.

Opposition to these secular prophecies was aroused on the Continent as well as in England. Belief in them was prevalent over Europe in the fourteenth century. ${ }^{74}$ Effective opposition seems not to have been aroused until in the sixteenth century. The attacks came from various quarters. The Prophecies of Merlin were put on the list of proscribed books in the Index librorum prohibitorum according to a rule passed by the Council of Trent that books relating to fortune-telling, soothsaying, divination, augury, astrology, magic, or prophecy should be condemned..$^{75}$ Other prophecies were put on the same list. In France, "political prophecies through the

${ }^{73}$ See Kampers, von Dollinger, and Chevalier passim.

${ }^{74} \mathrm{~F}$. Tocco-Il Savonarola e la Profezia, in Vita Italiana nel Rinascimento, Milan, I899, 236-268, passim.

${ }^{75}$ Index Librorum Prohibitorum, Venice, 1564, f. 7 b., I7 a. 
medium of almanacs grew so alarming, and possibly personal in their character, that Henry the Third of France forbade such to be inserted therein, which prohibition was repeated by Louis the Thirteenth as late as 1628. At a much earlier date every almanac had to be stamped with the approval of the Bishop of the Divorce before publication." 76

Like Bacon in England, who treated of Prophecies in one of his Essays, Montaigne in France devoted an Essay to Prognostications. ${ }^{77}$ His attitude is one of contempt. He calls to mind the madness of Francis Marquis of Saluzzo, who was misled by a belief in what Montaigne called 'fond prognostications,' which then throughout Europe were given out to the advantage of the Emperor Charles the fifth. Montaigne says further : " "I see some that studie, plod and glosse their Almanackes, and in all accidents alleage their authoritie. ... I think not the better of them, though what they say proove sometimes true." In characterizing the prophetic style he says, "But above all, their dark, ambiguous, fantasticall, and propheticall gibrish, mends the matter much, to which their authors never give a plain sense, that posterity may apply what meaning and construction it shall please unto it."

The different nations of Europe had different prophecies to fit individual needs. In addition to these national prophecies were others not touched upon in this study. They were chiefly religious in content, and concerned themselves with the affairs of the Church, such as the prophecies of Rupescissa. Two themes, however, recur time and again in the different countries, sometimes combined into one. They are The Returning Hero who should be a political savior, and The Last King of Rome. The expectation of a political savior misled the Jews at the time of Christ. The Nero-saga, which the Christians identified with the Anti-Christ theme, served the Romans for a returning hero. In the Byzantine Empire the theme was combined with the Last-King-of-Rome to make the L.-prophecy, mis-

${ }^{76}$ Samuel Briggs, The Origin and Development of the Almanack, in Western Reserve and Northern Ohio Historical Society Tracts, 1887, no. 69, pp. 435-477.

${ }^{77}$ Montaigne's Essays, trans. by John Florio. London, 1901, I, 55.

${ }^{78}$ Ibid., I, 57. 
called the Constans-prophecy, from Methodius down to the. fifteenth century. On British soil it concerned itself with Arthur and Richard the Second. In Germany it became the Kaiser-saga centering around Barbarossa. In Portugal as late as the seventeenth century it was associated with the memory of King Sebastian, and was used to encourage the Portugese to hope for freedom and separation from Spain. ${ }^{79}$ A similar prophecy was said to be current in Servia at the time of the recent revolution which changed dynasties, and put King Peter on the throne.

Much has been said from time to time of the Last-King-ofRome theme, the origin of which was discussed in the second chapter. It existed in both the Eastern and Western Empires. The first modification of it was made in France, where the belief was current in the ninth century that the Last King should be a Frenchman. In England a further modification made him an Englishman. The English version seems to have been accepted for a time, at least by some few people, on the Continent, if the prophecy of Rupescissa is to be considered any indication. The French version was revived in the fourteenth century. A further modification of it promised that the Last King should be named P., ${ }^{80}$, who was identified by Lichtenberger as Philip of Austria, the son of Maximilian by Mary of Burgundy, a French Princess. ${ }^{81}$

${ }^{79} \mathrm{~J}$. von Döllinger, Der Weissagungsglaube und das Prophetenthum in der Christlichen Zeit, Historiches Taschenbuch, series 5-vol. I, Leipzig, 1871, 259 f., p. 280 .

${ }^{80}$ Veit Arnpeck quoted by Kampers, 165; Wolfgang Aytinger, Kampers, 183.

${ }^{81}$ Lichtenberger according to Kampers, 182. 


\section{APPENDIX I}

THE SIX KINGS TO FOLLOW KING JOHN

It was shown in the third chapter of the present study that The Six Kings is derived originally from certain phrases in The Book of Merlin. Besides these phrases there are four other versions of the same material. The oldest seems to be a Latin version found in ms. Harleian 6148. The second in time is an Anglo-French version in ms. Harleian 746. The other two are English versions, of which one is in prose and the other in verse. The prose form is found in The Brut. The verse form has already been discussed in the third chapter.

A

THE LATIN VERSION

Vaticinium cuiusdam spiritus tempore regis Johannis.

Harleian 6r48. A manuscript of the early seventeenth century containing prophecies written down by Sir Richard St. George, Clarenceux and headed "De quibusden vaticiniis ex vetusto libro manuscripto." (Ward, loc. cit., I, 21I.) This version would seem to have been made before Edward the First's conquest of Scotland, at least before the accession of Edward the Second.

(Orietur draco de asino qui in bracchio suo potentissimo suos \& mulos et raptores superabit rex fidellisimus erit pius deo et hominibus placens terram superbie conculcabit et recuperabit) $^{1}$. Extincto ${ }^{2}$ herede regnans glorians in malicia perplexus inquietudine minuetur et dies eius (anticipabitur) anticipabunt veneno, exiit agnus a Wintonia lanam habens albam et labia veracia et scriptum corde suo sanctitas, agnus ille construet deo domum quandam aspectus pulcherrimi sed non perficiet suo tempore versus finem regni eius, et cum

1 These lines have been erased in the ms. but are still legible.

2. In the margin, Rex $H$ 3tius Agnus. 
obierit erit semen eius in terra extranea et sic demorabitur terra sine pastore pro tempore sed tempus erit satis breve.

Post $^{3}$ tempus agni succedet ei draco misericordie mixti ferocitati barbam habens capream dantem umbram universali terre anglie, qui incolas custodiens a frigore et calore unum pedem suum ponet in Wik et alterum in London amplectur sibi tres habitationes et os suum appariet versus Walliam et faciet eam tremere cum gente terre illius ob timorem eius alas suas extendet in plures patrias hanelitus eius erit tam dulcis quod plures veniet aliegenas qui alias ei guerram suscitarent et ferrent multa damna, tempore suo current rivi sanguinis et construet muros quod gravabit semen eius.

Post $^{4}$ mortem draconis succedet capra argentea habens cornua et barbam ut austurcium et ex naribus eius exibit nebula orignans dolorem et grave dampnum famis et ...5 mortalitatem et amissionem partis terre illius, initio regni illius erit luxuria sordescens et putrescens vigens in duabus nobilibus statubus et mediocribus pari forma tempore suo peribit magna pars populi terra sua in dolore et erumpnia et quod aliegene prestantiores erunt super eum, tempore suo fluvius oste clarescet et parebit quod ardeat, bellum quoddam erit in campo paratum ut scutum super Bracchium maris et post bellum sese gentes amitterent grosso modo velut pisces maris, et in bello illo morientur quam plures albores capitum propter quod nuncupatur album bellum quamdiu perseverat capra in tribulationibus et inquietudine erit vita illius et in arumpnia transitus eius, et post dies demorabitur terra nimis repleta aliegenis et in magna tribulatione erit terra post mortem eius. Cum autem desierit esse capra succedet Aper ${ }^{8}$ caput gestans aureum, cor leoninum, affectum pietatis vultus eius erit requies fidelibus, pectus eius erit extinctio scitis qui scitum pacientur loquela eius habebit laudem difelitatis gestus eius humilis ut agnella, inicio regni sui satis tedii pacietur ad justificandos infideles et malefactores terrae suae. Aper ille per medium ferocitatis cordis sui compellet

${ }^{3}$ In the margin, Rex Ed primus Draco.

"In the margin, rex Ed ads Capra.

${ }^{5}$ I cannot decipher this word.

${ }^{6}$ In the margin, Rex Ed 3tius Aper. 
lupum devenire agnum et vocabitur per universam orbem Aper caritatis ferocitatis et nobilitatis in Justicia erit humilis ut agnus.

Apro illi succedet asinus ${ }^{7}$ habens pedes plumbeos caput asseret cor aneum pellem quasi ferream dura bestia erit iste et in tempore suo erit terra valde pacifica inicio regni sui edificabit fideles erit clamor eius audietur per univeram orbem. Asinus pro fidelitate sua amittet magnum partem terrae suae per quendam lupum terribilem qui regnabit et asinus dabit dominium terrae suae cuidam aquile regnans vero bene se gubernabit usque as tempus quo superbia ipsius superabit. Heu. Heu. quod obibit per gladium fratris sui.

Post asinum veniet talpa ${ }^{8}$ ore dei maledicta superba misera et turpida vindicta cadet super eam pro peccatis antefactis, elata et maliciosa erit, terra revertetur ad asinum et aprum et ipse Gubernabit totam terram in pace dum vixerit et remanebit terra repleta omnibus bonis.

Aper $^{9}$ ille exibit a Win et exibit exacuens dentes suos per iiij terras et audacter perficiet agenda sua circumcirca Jherusalem. hispania tremet et titillabit a timore eius, in Aragonia et in Francia ponet omnium ${ }^{10}$ suum et magna cauda sua requiescat in Anglia ubi natus erat. Aper ille dentes suos acuet supra muros parisiae, Albania titillabit ob timorem, Aper ille diu durabit ad duas villas anglie faciet aper ille rivulos sanguinis et cerebri discurrere et prata virida in rubea transmutabit, aper ille recuperabit quicquid antecessores sui perdiderunt per universas terras et gestabit tres coronas antequam obierit, ipse quoque reducet quandam terram in magnam subjectionem sed ispa revelabitur non tamen in tempore suo. Aper satis amplius conquestabit quam aliqui antecessores suores antequam fecerunt. Omnes in hoc mundo se sibi melenabunt et terras suas conservabit in pace bona dum, in terra aliena morietur, et ob nobilitatem eius inter tres reges sepulietur.

${ }^{7}$ In the margin, rex $R i$ ad Asinus.

${ }^{8}$ In the margin, rex $H$ qtus talpa.

${ }^{\circ}$ In the margin, Ed 3tius. This part was evidently written later than the preceding and added to it. The material contained in it is worked into the context of the later versions.

${ }^{10} \mathrm{I}$ can make nothing else of the manuscript here. Omnium is evidently not the right word in this place. 


\section{Merlin's Prophecy of the Six Kings}

Harleian 746. A ms. of the thirteenth century. Written on the first fly leaves of a collection of treatises in Latin and French, chiefly legal, the first of which is the Tractatus de Legibus of Ranulph Glanvis, written in the thirteenth century. The volume appears to have belonged to Hugh Obthorp, of Baston, co. Linc., in the fourteenth century, and subsequently to John Warner, chaplain of Sutton, co. Lincoln. (Ward, loc. cit., $\mathrm{I}, 309$.

I comencent asqunes des prophecies et des mervailes que Merlin dit en son temps d'engleterre Et des rois ke unt este puis le temps que le roi Henri d'arain nasqui a Wincestre Et des rois que serrount bones et males moles et dures

Un aignel vendra hors Wincestre qu'avera blaunche launge et levers veritables et avera escrit en son quoer saint Cel aignel ferra une mesone de dieu que serra de bele veue mes ele ne serra parfete en son temps En la fin de son regne vendra un lou d'estrange terre et habitera en son regne si lui ferra mout grant damage et levera grant guerre mes au fin serra l' aignel meistre et veincra le lou par l'eide d'un rouge gopil que vendra hors de northest et le lou enveiez Et apres cel temps ne vivera gers l'aignel Et a cel houre qu'il morra serra son semail en estrange terre si demorra la terre saunz pasturel jusques a un temps mes le temps serra court Apres son temps vendra un dragon de merci modlee et de fierte et avera barbe com chevre que dorra umbre a Engleterre si le gardera de froit et de chaut si mettera un de ses pies en Wik et l'autre en Lond Si embracera trois habitatouns et overa sa bouche de vers gales et la fera mout fremer de pour oue la hidour de so bouche Ces orailes se tendreunt en plusours pais. Sa aleine serra si douze que venkera meint d'estrange terre que li leverount guerre et lui ferrount grant damage En son temps corrount de sauncs et il ferra sours que nuera son s. ${ }^{11}$. . . Apres cel temps vendra un poeple hors de Northwest que serrount amenes par un mauvus leverer que morrount a grant dolour souz ceste de mer

${ }^{11}$ A wrinkle in the page here obscures the word in the photographs from which I transcribe. 
saunz nombre En son temps sera le solail rouge com saunz a veue de tut le monde si signefiera la grant mortalite du sauncs que serra espandu de Cristiens par cop d'espeie. Ceux gentz demorrount orphanins jusques a un temps et en plousours autres ennuez. Celi dragon norira un gopil que li menera grant guerre. En la fin de sa vie ne serra pas finie en son temps mes tous ses enemis veincra si serra tenus de nobles $\mathrm{so}^{12} \ldots$ d'autre terre si demorra . . . pasturel si ploraunt des oiz por sa mort allas serra ... com d'une gentz orphanins que remeindrount en terre de gaust Apres sa mort vendra un chevre que avera corns d'argent et barbe com hostour et istera de ses narils une broume que signefiera does et grant damage famine et mortalite des gentz et perte de terre En le comencement de son regne lecherie serra orde et puneise en son temps des grantz Dames et des mennes grantment Icelui chevre vendra hors de Car et irra en paenie si quera flour de vie En son temps morrount a doel et a grant dolour un poeple de sa terre par quei ceux d'estrange terres serrount en bandes sur lui En son temps serrount fait forteresses des armes la fosse dou ler peres chomu si serrount pleines la ou chasteux soleint estre En son temps serra ouse esclari et parira quele arde $E$ un bataille serra en chaunp taille com estu sur bras de mer Et apres cel bataille si perderount les gentz en gros com poissonns $\mathrm{E}$ a cel bataille morrount mout des blanches testes si serra apelle la blaunche bataille Un ours ferra a cel chevre mout de mal que serra de son saunc et le chevra perdera mout de sa terre taunque a un temps que hunte li veincra si vestira d'un pel d'un leon et regainera ce qu'il avera avaunt perdu et plus

Et un poeple grant vendra de Northwest que lui ferrount entrelier et lui serrount cheremuz et doutez et lui vengerount

12 The right hand corner of the manuscript is mutilated so that the end of the first 3 lines on each page is lacking. In the Brut this passage reads: "This dragoun shal bene holden in his tyme the beste body of al be worlde; et he shal dye bisides be Marche of a straunge lande; and be lande shall duelle faderlesse wibouten a gode gouernoure; and me shal wepe for his deb fram be Ile of Shepe vnto be haven of Marcill; wherfore, 'allas' shal bene be commune songe of the faderles folc, bat shal ouerleuen in his land destroiede." (The Brut, p. 73.) 
de ses enemis et il vivera tout son temps en enui et en travaille et en paenie morra

Et apres sa mort demorra la terre mout repleine des aliens si avera la terre grant trebulation apres sa mort $E$ en le temps de cel chevre avaunt dit surdra un Egle de Cornwaile et avera pennes d'or et finira en Gavaru Apres cel chevre vendra un sengler que avera la teste sen et quoer de leon regard de pite son visage serra repos as malades sa poitrine estaunchemente de soif a ceux que soif averount sa parole loaunge de leaute son port humble com aignel. En son temps en comencement de son regne avera grant onnui a justicier les de leaux mefesaunz Celui sengler parmi le fier quoer qu'il avera ferra le lou devenir aignel si serra apelle par tote le monde sengler de saunte et de fierte et de noblesse En dreiture humble com aignel Cel sengler vendra hors de Winde et irra en anguissanz ces dentz par quater terre et ferra hardiment ces qu'il avra a faire jusques a Burgh de Jherusalem Espanie tremblera de poure de lui Aragoun estrevera En France mettera ${ }^{13}$... posera en Engleterre ou il fuist nee ${ }^{14} \ldots$ en anguisera ces dentz sur les portes de Paris. Alemanie fremera de pour de lui Celui sengler durera meint temps a deux villes en Engleterre Celui sengler ferra russeaux de sant Et cervel et verte pres rouge Cel sengler regainera quanquez ces auncestres unt avaunt perdu En totes terres si portera trois corounes avaunt qu'il moerge so mettera une terre en grant subjection me ele relevera noun pas en sa vie Cel sengler conquerra plus que unques nul de son saunc en iceste munde Tous lui enclineront et les terres tendra en bon poes en sa vie Si murra en estranges si serra por sa noblesse enterre entre les trois rois

Apres cel sengler vendra un asne et avera pies de plum et teste d'asser quoer de arren et pelecon fere durre beste serra En son temps serra la terre mout en pees Et en le comencement de son regne si enedifiera Oue serra sa crie par tout le

${ }^{13}$ The Six Kings poem must guide us here. The passage reads,

"In France sall he sett his heuid biforn.

His tail sal rest in Yngland whare he was born." (1. 170)

The Brut reads wing for head and omits the last clause.

${ }^{14}$ Neither The Brut nor the poem gives assistance here. 
munde Cel asne perdera par sa lechite un grant partie de sa terre par un lou hidous mes il regnera si dorra a un Egle seignurire de ces terres Cel egle se governera bien taunquez a un temps que orguile lui surmuntera allas quel damage car il murra par le espeie son frere la terre rercherre a l'asne et celui governa la terre repleine de touz biens

Pres cel assne vendra un talpe maudit serra de la bouche dieuz orguilous cheteif et coward serra pel avera come chevre vemaunte cherra sur lui par pecches avaunt fetes horrible et malveis serra En le comencement de son regne avera mult . . . ${ }^{15}$ leaute vers lui de touz biens et serra en grant loaunge jusques a un temps que orguil li sur muntera et' vil pecche ... ${ }^{16}$ surdra un dragun que serra mut. Perillous ${ }^{17}$ et mut horrible et movera grant guerre de vers la talpe Cele guerre serra funde sur un piere Cel dragoun aqueilera en sa compaigne un lou vendra hors del West et movera guerre de vers le talpe de sa part si lierount le dragoun et le lou ensemble oue un leon que vendra hors d'irlaund que se compaignera a eux Lors tremblera Engleterre com foil de sapine $E$ en cel temps avera le talpe mout grant pour si quoilera son poeple si serra descomfit a grant dolour En son temps trebocherount les chasteux sur Thames Esi para que sauerne secche por les corps que de dens giserount Les quatre chefs . . ${ }^{18}$ corrount de saunc mountaingnes leverount ... ${ }^{19}$ s'enfuera por pour Le dragoun le cha ... ${ }^{20}$ et le leon le terre demorra saunz ${ }^{15}$ The poem reads,

\section{"In be land sal be at his biginning, Plente of none and all ober thing."}

The Brut reads, "In be ferst ere of his regne he shal have of al gode grete plente in his lande, and toward him also.

${ }^{16}$ The poem and The Brut read Then in this place.

${ }^{17}$ The poem reads, "ful fell et ful scharp"; The Brut, "ful fers."

${ }^{18}$ The Brut reads, "be iiij chief flodes of Engeland."

19. The poem reads, in this place,

" pe grete hilles for drede clouen sall be, And be moldwerp for ferd sall oway fle."

The Brut omits the passage entirely.

${ }^{20}$ The Brut, " and be dragoun, be lyoun and be wolf, him shaldryuen away." 
Pasturel ... ${ }^{21}$ n'avera fors que la neef ou il estoinz et ... ${ }^{22}$ retret de la mer et il dorra les deux parties de sa terre et la tierte ... ${ }^{23}$ partie en pees $\mathrm{Si}$ vivera en grant dolour... ${ }^{24}$ Enson temps devendra le chaunt lain froit Si morra . . . ${ }^{25}$ mort en son chemin de vers pecche quar il serra en $\mathrm{fl} \ldots{ }^{26}$ son semail devendra por touz jours en estranges terres . . . ${ }^{27}$ serra la terre d'engleterre departie en trois entre le Dragoun et le lou et le leon si serra tost en apres cele temps terre de conqueste. E si finerount les heirs d'engleterre hors de heritage.

Besides these four versions of The Six Kings material, another very interesting form of it is found in the poem entitled John the Hermit in Ms. Hatton 56, f. 43 a-44 b. The author of this poem has taken material from every episode in the complete version and written a poem centering around only one figure, the Ass. I do not print this poem because it is long and would add little in this place to the history of The Six Kings, but I hope to publish it at some future date and to use it as the basis of a more complete study of the whole material.

${ }^{21}$ The Brut, " and be Moldewerpe shal haue no maner power, saf onely a shipp."

${ }^{22}$ The Brut, "and after bat, he shal come to lande when be see is wibdraw."

${ }^{2}$ The poem, "be twa partes sall he gif oway of bat land."

${ }^{24}$ The poem, "In were et wandreth."

${ }^{25}$ The Brut, "for he shal bene drenchede in a flode of be see."

${ }^{26}$ The Brut, "for euermore." 


\section{APPENDIX II}

\section{SAINT THOMAS OF CANTERBURY}

\section{Ms. Hatton 56, f. 45-46 b. Bodley Library}

Thomas rides from rome be man bat right kennes he fares forth by a faire towne Pise it is hotyn There fyndes he masons upon a toure makand A belfry of alabastre bere belles shul hengyn Thomas to be work went ware was sone Of a lovely Image of our lady bat he most loved Sho was tired in a tabernacle \& no man of hyr toke hede Than Thomas called the maistre mason bat be work makid Sey sir by mi fay whi hast bou so lowe set This semely lady with hir son prince of al other have here $\mathbf{x x}$ marc $\&$ make many for to sit closid in a caruell riche. feire for to se And whan Thomas was boune to pas to be Image he se. Byleve wele my lady. with bi son so fre And be my frend lady where so I go The Image louted \& al the toure after bowed $\&$ So it hangyth yit on held; I say be for sothe Thomas busked til a burgh basile is hotyn A siker citie for soth in Almayn it stands This kene clerk of Canterbery faris til a kirke byddes graithe hym an auter \& dresses hym to synge As he was busked $\&$ boun his boke ban hym lakked and seid he forgate it at rome with be pope right and my weddid brother wele worthe hym ever As he had made his mone mary him herd sone and lete fal on be auter a ferly feire boke with lomyned lies laughan upon hym Ilke kyndly clerk myght rede it hym selve Thomas takys be boke \& mary with hert thankes.

(Here the printed version begins.)

Of bat jewel bat was hym taken for bat ilk lady.

This poem continues for seventy-two lines, but I do not consider its differences from the printed version important enough to justify publishing the remaining lines. 


\section{THE COLUMBIA UNIVERSITY PRESS}

Columbia University in the City of New York

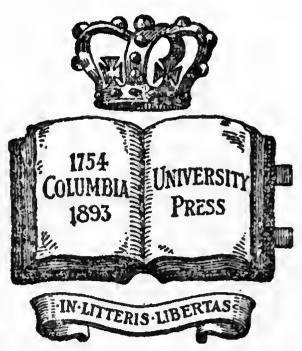

The Press was incorporated June 8, 1893 , to promote the publication of the results of original research. It is a private corporation, related directly to Columbia University by the provisions that its Trustees shall be officers of the University and that the President of Columbia University shall be President of the Press.

The publications of the Columbia University Press include works on Biography, History, Economics, Education, Philosophy, Linguistics, and Literature, and the following series :

Columbia University Biological Series.

Columbia University Studies in Classical Philology.

Columbia University Studies in Comparative Literature.

Columbia University Studies in English.

Columbia University Geological Series.

Columbia University Germanic Studies.

Columbia University Indo-Iranian Series.

Columbia University Contributions to Oriental History and Philology.

Columbia University Oriental Studies.

Columbia University Studies in Romance Philology and Literature.•

Blumenthal Lectures. Hewitt Lectures.

Carpentier Lectures. Jesup Lectures.

Julius Beer Lectures

Catalogues will be sent free on application.

Lemcke \& Buechner, Agents 30-32 WEST 27th ST., NEW YORK 


\section{STUDIES IN ENGLISH}

Joseph Glanvill. By Ferris Greenslet, Ph.D., Cloth, ramo, pp. xi +235 , $\$ 1.50$ net.

The Elizabethan Lyric. By John Erskine, Ph.D., Cloth, r2mo, pp. xvi $+344, \$ 1.50$ net.

Classical Echoes in Tennyson. By Wilfred P. Mustard, Ph.D., Cloth, I 2 mo, pp. xvi + I64, \$1.25 net.

Sir Walter Scott as a Critic of Literature. By Margaret Ball, Ph.D., Paper, 8vo, pp. $\mathrm{x}+\mathrm{r} 88, \$ \mathrm{r} .00$ net.

The Early American Novel. By Lillie Deming Loshe, Ph.D., Paper, 8vo, pp. vii + I3I, \$1.00 net.

Studies in New England Transcendentalism. By Harold C. Goddard, Ph.D., Paper, 8vo, pp. $\mathrm{x}+217$, \$1.00 net.

A Study of Shelley's Drama "The Cenci." By ERnest Sutherland Bates, Ph.D., Paper, 8vo, pp. ix + ro3, \$1.00 net.

Verse Satire in England before the Renaissance. By Samuel Marion Tucker, Ph.D., Paper, 8vo, pp. xi + 245, \$r.0o net.

The Accusative with Infinitive and Some Kindred Constructions in English. Вy Jасов Zeitlin, Ph.D., Paper, 8vo, pp. viii + 177, \$1.0o net.

Government Regulation of the Elizabethan Drama. By Virginia CroCheron Gildersleeve, Ph.D., Cloth, 8vo, pp. vii +259 , \$1.25 net.

The Stage History of Shakespeare's King Richard the Third. By AlICE I. Perry Wood, Ph.D., Cloth, 8vo, pp. xi + r86, \$1.25 net.

The Shaksperian Stage. By Victor E. Albright, Ph.D., Cloth, 8vo, pp. $\mathrm{xii}+194, \$ 1.50$ net.

Thomas Carlyle as a Critic of Literature. By Frederick W. Roe, Ph.D., Cloth, 8vo, pp. xi + 152, \$1.25 net.

The Authorship of Timon of Athens. By ERnest Hunter Wright, Ph.D., Cloth, 8vo, pp. ix + 104, \$1.25 net.

English Tragicomedy, Its Origin and History. By Frank H. Ristine, Ph.D., Cloth, 8vo, pp. $\mathrm{xv}+247, \$ 1.50$ net.

Lemcke \& Buechner, Agents, 


\section{STUDIES IN ENGLISH}

Leigh Hunt's Relations with Byron, Shelley and Keats. By Barnette M'iller, Ph.D. 8vo, cloth, pp. vii + I69. Price, \$1.50 net.

The Rise of the Novel of Manners. By Charlotte E. Morgan, Ph.D. 8 vo, cloth, \$1.25 net.

John Dennis. His Life and Criticism. By Harry G. Paul, Ph.D. 8vo. cloth, \$1.25 net.

New Poems of James VI. and I. By Allan F. Westcott, Ph.D. 8vo, cloth. In press.

The Middle English Penitential Lyric. By Frank Allen Patterson, Ph.D. 8vo, cloth, \$1.25 net.

The Exemplum in the Early Religious and Didactic Literature of England. By Joseph Albert Mosher, Ph.D. 8vo, cloth, \$1.25 net.

The Soliloquies of Shakespeare. By Morris LeRoy Arnold, Ph.D. 8vo. cloth, \$1.25 net.

The Political Prophecy in England. By Rupert Taylor, Ph.D. 8vo, cloth, \$1.25 net.

\section{STUDIES IN COMPARATIVE LITERATURE}

Romances of Roguery. By Frank Wadleigh Chandler, Ph.D. Part I. The Picaresque Novel in Spain. I 2 mo, cloth, pp. ix +483 . Price, $\$ 2.00$ net.

A History of Literary Criticism in the Renaissance. By Joel Elias Spingarn, Ph.D. Second edition, revised and augmented. I $2 \mathrm{mo}$, cloth, pp. $x i+330$. Price, \$I.50 net.

Platonism in English Poetry of the Sixteenth and Seventeenth Centuries. By John Smith Harrison, Ph.D. I 2 mo, cloth, pp. xi +235 . Price, $\$ 2.00$ net.

Irish Life in Irish Fiction. By Horatio Sheafe Krans, Ph.D. I 2 mo, cloth, pp. vii +338 . Price, \$I.50 net.

The English Heroic Play. By Lewis Nathaniel Chase, Ph.D. izmo, cloth, pp. xii +250 . Price, $\$ 2.00$ net.

The Oriental Tale in England in the Eighteenth Century. By Martha Pike Conant, Ph.D. I2mo, cloth, pp. xxvi + 312. Price, $\$ 2.00$ net.

The French Influence in English Literature. By Alfred Horatio Upнам, Ph.D. I 2 mo, cloth, pp. ix +560 . Price, $\$ 2.00$ net.

The Influence of Molière on Restoration Comedy. By Dudley $H$. Miles, Ph.D. I 2 mo, cloth, pp. $x i+272$. Price, \$1.50 net.

The Greek Romances in Elizabethan Prose Fiction. By Samuel LeE Wolff, Ph.D. 8vo, cloth. Price, \$1.50 net.

Lemcke \& Buechner, Agents, 


PLEASE do NOT REMOVE

CARDS OR SLIPS FROM THIS POCKET

\section{UNIVERSITY OF TORONTO LIBRARY}


